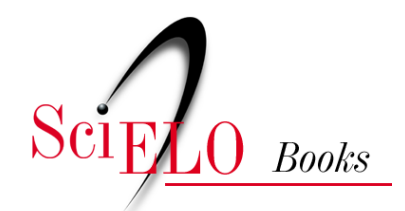

\title{
Saúde mental e reabilitação psicossocial avanços e desafios nos 15 anos da Lei 10.2016 (Proceedings)
}

\author{
Sônia Barros \\ Luís Eduardo Batista \\ Jussara Carvalho dos Santos \\ (organizadores)
}

\section{SciELO Books / SciELO Livros / SciELO Libros}

BARROS, S., BATISTA, L.E., and SANTOS, J.C., comps. Saúde mental e reabilitação psicossocial: avanços e desafios nos 15 anos da Lei 10.2016 [online]. Uberlândia: Navegando Publicações, 2019, 167 p. ISBN: 978-65-81417-07-9. https://doi.org/10.7476/9786581417079. Transcrição dos Anais do II Encontro de Saúde Mental - Reabilitação Psicossocial: avanços e desafios 15 anos após a Lei 10.216, Uberlândia, MG, 2016.

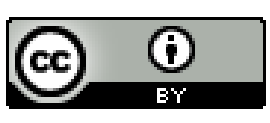

All the contents of this work, except where otherwise noted, is licensed under a Creative Commons Attribution 4.0 International license.

Todo o conteúdo deste trabalho, exceto quando houver ressalva, é publicado sob a licença Creative Commons Atribição 4.0.

Todo el contenido de esta obra, excepto donde se indique lo contrario, está bajo licencia de la licencia Creative Commons Reconocimento 4.0. 


\section{Comissão editorial}

Anaísa Cristina Pinto Carolina J. S. Salado Cristhian R. Schieck Lara S. Messias Floriano Laís Mariana da Fonseca Luciane Régio Martins Naira Gajo Silva

Transcrições dos vídeos do Evento

Empresa Brasil Transcrições

\section{Agradecimentos especiais}

Aos setores de informática e comunicação da EEUSP representados por Marcos Vieira. À Luciane Régio Martins pela gravação cuidadosa de todo evento.

À Comissão organizadora do II ENCONTRO DE SAÚDE MENTAL E REABILITAÇÃO PSICOSSOCIAL: AVANÇOS E DESAFIOS NOS 15 ANOS DA LEI 10.216.

Ao apoio da Área técnica de saúde mental da Secretaria Municipal de Saúde de São Paulo, DECIT/ Ministério da Saúde, CAPES, CNPq, FAPESP, CRP/SP, CEAPE/EE, o qual possibilitou a realização do evento em 2016 


\section{Organização}

Sônia Barros Luís Eduardo Batista

Jussara Carvalho dos Santos

\section{SAÚDE MENTAL E REABILITAÇÃO PSICOSSOCIAL}

\section{AVANÇOS E DESAFIOS NOS 15 ANOS DA LEI 10.216}

NAVEGANDO

Uberlândia, 2019 


\title{
Copyright (c) 2019 dos autores
}

\section{Todos os direitos desta edição reservados}

\section{Capa, projeto gráfico e produção do arquivo ePub}

\author{
fkeditorial
}

\author{
Catalogação na Publicação (CIP) \\ Biblioteca "Wanda de Aguiar Horta" \\ Escola de Enfermagem da Universidade de São Paulo
}

\section{S255}

Saúde mental e reabilitação psicossocial: avanços e desafios nos 15 anos da Lei 10.2016 / organização de Sônia Barros, Luís Eduardo Batista e Jussara Carvalho dos Santos. - Uberlândia: Navegando, 2019.

$168 \mathrm{p}$.

ISBN 978-65-81417-07-9 (e-book)

1. Saúde mental. 2. Reabilitação psicossocial. 3. Desinstitucionalização. 4. Direito à saúde. 5. Enfermagem psiquiátrica. I. Título.

CDD: 614.58

Ficha catalográfica elaborada por Fabiana Gulin Longhi Palacio (CRB-8: 7257)

2019

Editora Navegando

https://www.editoranavegando.com/

Edição digital: janeiro de 2020 


\section{Table of Contents / Sumário / Tabla de Contenido}

Front Matter / Elementos Pré-textuais / Páginas Iniciales Apresentação

Apresentação 9

Conferência de abertura - Direitos Humanos

e a Saúde Mental: estratégias para o avanço

das políticas de saúde mental $\quad 11$

Prof. Dr. Benedetto Saraceno 11

Mesa redonda - Reforma psiquiátrica no Brasil: avanços e desafios

Prof. ${ }^{a}$ Dr. ${ }^{a}$ Ana Maria Fernandes Pitta $\quad 25$

Dr. ${ }^{a}$ Sandra Maria Sales Fagundes 31

Sônia de Fátima Rosa 36

Mesa redonda - Avanços e desafios da lei no. 10.216/2001 43

Sr. Paulo Gabriel Godinho Delgado 43

Prof. Dr. Sérgio Souza Verani 52

Prof. Dr. Pedro Gabriel G. Delgado 59

Mesa redonda - Convenção dos Direitos das pessoas com deficiências e a lei n. ${ }^{\circ}$ 10.21669

Convenção dos Direitos das Pessoas com Deficiências e o Quality Rights - Prof. Dr. Roberto Tykanori Kinoshita 69

Direitos dos usuários de serviços de saúde mental — Prof. Dr. Jefferson Aparecido Dias 77

CAPS e Quality Rights - Fernanda Nicácio 
Mesa redonda - As estratégias e instrumentos de inclusão social e os direitos das pessoas com transtornos mentais em conflito com a lei $\mathbf{8 9}$

Programa de atenção integral ao paciente judiciário portador de sofrimento mental (PAI- PJ) Minas Gerais - Dr. ${ }^{a}$ Romina M. de Magalhães Gomes $\quad 89$

A experiência italiana do fechamento de hospitais psiquiátricos judiciais - Dra Giovanna del Giudice 97

Programa de atenção integral ao louco infrator (PAILI) - Dr. Haroldo Caetano da Silva $\quad 102$

Conferência - Políticas públicas no contexto da crise do estado de direito $\quad 113$

Prof. Dr. Aldo Fornazieri 113

Mesa redonda - Ações dos serviços territoriais para inclusão social $\quad 125$

Prof. Dr. Benedetto Saraceno 125

Dra Giovanna del Giudice 129

Prof. ${ }^{a}$ Dr. ${ }^{a}$ Sônia Barros 134

Palestra — Direitos e cidadania dos usuários de álcool e outras drogas 143

Dr. Antônio Lancetti 143

Palestra - A luta antimanicomial e a construção dos direitos e das políticas na área de saúde mental 151

Prof. Dr. Paulo Duarte de Carvalho Amarante 151

Notas 167 


\section{Apresentação}

O Grupo de Pesquisa Enfermagem e as Políticas de Saúde Mental (GEnPSM), da Escola de Enfermagem da Universidade de São Paulo, realizou no período de 30/11 a 2/12/2016 o "II Encontro de Saúde Mental - Reabilitação Psicossocial: avanços e desafios 15 anos após a Lei 10.216".

A análise da conjuntura, daquele ano, indicava que, apesar dos notáveis avanços e conquistas da Reforma Psiquiátrica, a continuidade do seu desenvolvimento encontrava grandes obstáculos devido à resistência de alguns setores e corporações na área de saúde mental, que ainda defendem o modelo da psiquiatria tradicional, centrado na internação. Além disso, atos governamentais, tal como a nomeação de um Coordenador de Saúde Mental no Ministério da Saúde ligado aos interesses de hospitais psiquiátricos, denunciava séria ameaça de retrocessos na Política de saúde mental até então vigente no Brasil.

Assim, quando a Lei 10.216 completou 15 anos, tornou-se fundamental discutir os avanços e retrocessos da Reforma com seus idealizadores, inclusive os italianos que muito influenciaram a Reforma e também com gestores, trabalhadores, usuários e sociedade civil de forma a contribuir para a construção de novos conhecimentos e novas normativas.

Com a presença de cerca de 600 participantes, avaliamos que, na ocasião, o evento contribuiu para: A análise das Políticas de Saúde Mental; Ampliou a discussão sobre a Rede de Atenção Psicossocial; Subsidiou cientificamente gestores, trabalhadores, usuários, professores, alunos e profissionais dos sistemas de saúde e judiciário; Fortaleceu a difusão dos direitos dos usuários dos serviços de saúde mental. Posicionou-se em defesa do SUS e da Reforma psiquiátrica; Contribuiu com o processo de formação dos trabalhadores da saúde, alunos de graduação e pós graduação e gestores doSUS.

Os debates em plenário e na mostra dos trabalhos em comunicação oral favoreceram avaliação e proposições de transformação nas práticas de atenção em saúde mental nas RAPS. A riqueza dos trabalhos apresentados em comunicação oral, cerca de 60 selecionados, nos animou a publicar por meio eletrônico os Anais do II ENCONTRO DE SAÚDE MENTAL E REABILITAÇÃO PSICOSSOCIAL: AVANÇOS E DESAFIOS NOS 15 ANOS DA LEI 10.216, que está disponível no link https://2esm.blogspot.com/p/ programacao.html. 
A participação de convidados internacionais em Conferências e Mesas redondas, assim como de convidados nacionais reconhecidos por discutirem temáticas críticas sobre os rumos que a Saúde Mental tem tomado nas últimas décadas, e a participação de inscritos de diversos estados brasileiros possibilitou trocas de informação e de conhecimento critico acerca da situação da Atenção à saúde Mental no Brasil, que desde então vem sendo atacada numa tentativa de aniquilamento das históricas conquistas da Reforma Psiquiátrica Brasileira.

Desde a realização do evento e da publicação dos Anais, o GEnPSM considerando a notável importância e atualidade dessas participações, principalmente frente aos retrocessos que ameaçam as políticas públicas, especialmente da Saúde mental, pretendeu publicar as conferências e palestras realizadas no referido evento em um E book, pois já contávamos com a concordância por escrito de todos palestrantes envolvidos para o uso de suas palestras em futuras publicações. Foi uma longa jornada, para que, com parcos recursos realizássemos os passos necessários à publicação.

Assim, o Grupo de Pesquisa Enfermagem e as Políticas de Saúde Mental (GEnPSM) tem a honra de apresentar esta publicação que resulta das palestras realizadas no II ENCONTRO DE SAÚDE MENTAL E REABILITAÇÃO PSICOSSOCIAL: AVANÇOS E DESAFIOS NOS 15 ANOS DA LEI 10.216. Este evento realizou-se na cidade de São Paulo dos dias 30 de novembro a 02 de dezembro de 2016.

Aos palestrantes agradecemos a generosidade e lucidez das suas contribuições e pedimos desculpas se as transcrições e traduções deixaram erros nas intenções de fala.

Ao leitor, alertamos que este valioso material não é composto de textos preparados pelos autores para publicação, tal como para artigos. Trata-se sim, de vibrante diálogo com os participantes do evento que revela o compromisso de seus autores, o conhecimento, a emoção e os limites de tempo dado pela organização do evento.

Aos componentes do GEnPSM, nossa admiração pela realização do evento, que não contou com empresas para seu desenvolvimento, pelo esforço para a publicação dos Anais e deste e-book

Abril de 2019 


\section{Conferência de abertura - Direitos Humanos e a Saúde Mental: estratégias para o avanço das políticas de saúde mental}

\section{Prof. Dr. Benedetto Saraceno}

Médico, Psiquiatra, Ex-diretor do Departamento de Saúde Mental da Organização Mundial da Saúde, Docente da Universidade de Genebra, Suíça e Coordenador do Curso de Mestrado Internacional de Políticas e Serviços em Saúde Mental da Universidade Nova de Lisboa.

Desculpe, eu voy hablar en español. Com algumas palavras, as poucas que conoszco en português. Entonces vá a ser un portunhol. Eu acho que vamos ter essa dificuldade... entender a minha fala. Antes de todo, eu queria agradecer a Escola de Enfermagem da USP e a professora Sônia Barros por invitarme. Este evento - que é um evento importante - porque está em um contexto muy complicado, muy difícil do país, da saúde no país e da saúde mental. Nós es solamente um problema de agradecer, de maneira assim, formal, de cortesia. Sino de homenagear a professora Sônia Barros que durante toda a sua vida assim como uma acadêmica, uma pesquisadora, una maestra de muitos e de muitas que estão aqui. E ha sido, sobretodo una militante. Entonces agradecer pela sua contribuição militante, vigorosa ao processo de construção da reforma psiquiátrica no Brasil. Professora Sônia,obrigado.

\section{Ahora voy...}

Mi conferência se chama Connectivity, o sea, conexão. Fundamentalmente eu voy a falar de três tipos de connectivities. A conexão que existe entre os determinantes sociais e discapacidad. A segunda connectivity é a connectivity entre direitos humanos e desinstitucionalização. E a terceira connectivity é a connectivity entre a reabilitação e a reorientación ou reorientação do sistema saúde mental. Vamos pensar a primeira connectivity o sea, a connectivity entre determinantes sociais e discapacidad. A dimensão social pelas enfermedades mentales é uno componente fundamental da história natural das enfermedades e da enfermedad mental. La enfermedad e los determinantes sociales están en una relação circular. Se vocês quieren empezar a mirar esta circulari- 
dade pode ser que vá empezar por aqui. Vá empezar con una condición de problema de saúde mental. Vá empezar hacia la direita. O problema de saúde mental determina una iniquidade social. Por quê? Porque o paciente - tomamos um paciente com esquizofrenia - um paciente com esquizofrenia empeza a sua carreira de paciente baixando escalera de sua capacidad social. Perde o trabalho. A família se vá. Está islado. Consume o dinheiro da família.

Então assim: entra dentro de um círculo de pérdida de capacitação social. E eso determina um aumento da vulnerabilidade, que é uma vulnerabilidade de vida. A enfermidade se une à uma uma vulnerabilidade de vida, a pérdida de contractualidad social. Se o paciente entra na psiquiatria tradicional, no manicômio aún más. Entonces hay uma circularidad em que podemos empezar la Etapa 01, que é a enfermedad hacia pérdida da contractualidad social. Ou podemos empezar do outro lado: uma pessoa tem una pérdida da contractualidad social, porque está pobre, tem deuda. Porque está... Sufre de exclusão social e empeza a tener una vulnerabilidade social. E de la vulnerabilidade social marcha hacia um problema de saúde mental, hacia una enfermedad mental. Entón, que quer decir? Que hay lo que se llama risk reciprocity. O sea, una reciprocidade do riesgo. Tá. Mas que quiere decir?

Que as desigualdades sociales son fatores de riesgo para a saúde mental e que las enfermedades mentales son fatores de riesgos para desigualidades sociales. Esta relação... Não es que todas las enfermedades tengan la misma... mecanismo. É claro que enfermedades como depressão, uso de álcool e droga, transtorno de desarrollo de niño, adolescente são enfermedades que estão fortemente determinadas, por determinantes sociales: pobreza, exclusão social, falta de... Nível educacional muito baixo. Al revés, hay outras que son enfermedades que tem uma componente biológica importante, como a esquizofrenia. Pero no importa. Porque ellas entran também, de outro lado, na determinação da descença de la escalera social do paciente, o usuário. Hay una... Esta doble via, que se llama social causation, o sea, es una causa social la que vá determinar la enfermedad, o el social drift; es una enfermedad que vá determinar una pérdida de capacidade social. Hay un clássico que foi publicado en la revista Nature hace 20 años, que es um artículo fundamental. E foi escrito por um amigo de Brasil, um amigo da Reforma, o padre da Conferência de Caracas, o professor Isaac Levav, que escribió este artículo, que es un clássico da epidemiologia, em que mostra que há enfermedades que son determinantes de pérdida de valor social: depressão, alcoolismo e outras que vão en el otra direção. Porém, la pobreza, la deuda, la vulnerabilidad social, la depression, el suicidio son determinados por determinantes sociales. 
La esquizofrenia es un determinante de vulnerabilidade social de unemployed, de desempleo e finalmente, de pobreza. É un estudio muy interessante, que mostra que la capacidad econômica de um usuário que tem esquizofrenia quando tem 20 años, aos 30 anõs depois sua capacidade econômica ha diminuido $70 \%$. O sea, se ele tenía uma família, se ele tenía... O sea, se ha venido empobrecendo, o seu valor social. Ha venido empobrecendo sempre. Estamos hablando de uma connectivity entre determinantes sociales e discapacidad. O sea, los determinantes sociales son, determinam discapacidades. Eso es importante, una cosa teórica. Porque es una gran... Es una gran información para quién queira hacer reabilitação. Porque se hay una connectivity entre deteminante social e discapacidad, se nosotros queremos abordar discapacidad, nosotros que nos llamamos reabilitadores de la discapacidad. No podemos dirigirnos solamente hacia la discapacidad individual, do usuário. E sim dirigir-nos também hacia la desvantagem social em que o usuário se encontra. Eso é fundamental. No hay reabilitação piscossocial se hay solamente trabalho sobre a discapacidad individual do usuário. Eso es mala reabilitação. A boa reabilitação é una reabilitação que trabalha sobre a discapacidad individual e que trabalha também sobre a desvantagem social em que se encontra o usuário. Entonces el trabalho de reabilitação psicossocial é um trabalho doble: individual e de contexto. Toda a reabilitação da psiquiatria psicossocial está dirigida à discapacid individual do paciente.

Eu sempre dou o mismo exemplo, tomado da discapacidad física. Se um senhor tem uma discapacidad física porque no pude levantar a perna, no tiene la capacidad de hacer esto. Hay dos tipo de reabilitação. Hay una reabilitação que aprende o paciente a levantar mais a perna. E hay outra reabilitação que contemporaneamente aprende o paciente a levantar a perna e aprende também a cidade, o prefeito a baixar la grade do bus. Essa é a reabilitação. A reabilitação é um doble trabalho. Um trabalho para que o paciente aprenda a habilidades e o contexto social diminui a resistência hacia a discapacidad individual do paciente. Esta é a boa reabilitação. A reabilitação psiquiátrica de muñequitas, cenizeros, pintar... no disminuye la desvantagem social. Quizás no aumenta tampoco las habilidades do paciente. Esta conectividade que existe entre deteminantes sociais e a discapacidad. Porque a discapacidad tem dentro, en si misma, una componente social fundamental. A segunda conectividade é a conectividade entre os derechos humanos e a desinstitucionalização.

Bom, violaciones de derechos humanos. Quem sou eu para venir a Brasil falar de defensa de derechos humanos, saúde mental, o movimento, a história do Brasil, a luta aqui, manicomial é una história centrada sobre a lucha por los derechos humanos do paciente. Todos los países, alto y bajo ingreso son violadores de derechos humanos. Que 
hay un cuento, que hay un mito que las violaciones de direitos humanos na psiquiatria ocurren siempres nos países remotos, da África, siempre nos países exóticos. Não. Violação dos direitos humanos é uma violação sistemática que ocurre na Suécia, na Francia, na Alemanha, na Suíça. Na minha ciudad, donde eu vivo, Ginebra, é uma cidade... É um manicômio de 300 camas, com a gente amarrada à cama, com a cela de isolamento. $\mathrm{Na}$ Suíça. Têm bancos e violaciones de direitos humanos. Ambos. Nos países remotos, dos pobres, não tem banco e têm violaciones de derechos humanos. Está a diferencia entre a Suíça e o Cameroon.

Todos los ambientes terapêuticos pode ser lugar de violaciones de direitos humanos. Não é solamente um problema de hospital psiquiátrico. A violación de direitos humanos ocorria no hospital piquiátrico, no servicio da comunidade, na Casa de Medio Camino, num apartamento protegido. Na cárcel. Na casa mesmo do paciente. Esta não é una violação do derecho humano que está ocorrendo dentro da psiquiatria. Está dentro da comunidade. É a mesma comunidade que está violando direitos com o paciente, com o usuário. Eso es un niño, existem niños que estan encadenados. Não están en un hospital pisquiátrico, están no pueblo. Nesta comunidade que está violando direitos humanos. Eso es interessante. Eso es un templo religioso hindu que hace cuidado de salud mental com una cosa espiritual. Cosa espiritual por estar en una cadeira a pessoa. Eso es un hospital psiquiátrico. Eso es un hospital psiquiátrico da União Europeia. Interessante hã? Eso es un hospital psiquiátrico de um país membro da União Européia, que ha tomado a presidência da União Européia durante seis meses. Esse país, esse hospital psquiátrico forense, judiciário, da Lituânia, da cidade de Vilnius.

Entonces, em toda parte do mundo hay violação de direitos humanos. No se confundem: a pobreza da estrutura, da infraestrutura, da logística como sinal da violação de direitos humanos. Hay hospitales psiquiátricos muy pobres na África, por exemplo, donde hay menos violaciones de derechos humanos. E hospitales psiquiátricos muy limpios nos países do norte da Europa en que uno no vê a pobreza no contexto da logística, pero la violação dos direitos humanos, está. Entonces hay que tener um ojo inteligente para evaluar a presencia, maior ou menor do viés. O instrumento Quality Rights da Organização Mundial de Saúde, OMS, é exatamente isso. Ajuda a tener una mirada inteligente dentro do contexto de um local de saúde mental para ver se a violação de derechos humanos está ocurriendo, apesar do baño limpo, que é todo limpo, todo una maravilha. E violacíon hay. $\mathrm{E}$ a veces vai visitar hospitais psiquiátricos muito pequenos, pobres, de países africanos e um clima bastante humano. Apesar que o contexto, a logística é terrível. 
La Convención da ONU sobre os direitos das pessoas com discapacidad - no discapacidad mental - discapacidad en general é muito importante ter sido firmada e ratificada por Brasil. Então o tempo constitucional. Então se o Brasil viola a Convenção de Direitos, já firmado, pode ser posto em juicio internacional para a Corte. Eu penso que no próximo futuro eso es un instrumento que tenemos que utilizar mais. O sea, abogados que ponen en Corte Internacional o gobierno por violar a Convenção.

Que está firmado o governo nisso. E primeira característica desta Convenção que foi aprovada em 2008 e firmada em 2009 é que o físico e o mental estão juntos. A Convenção fala de discapacidad. Não de discapacidad mental, discapacidad... Discapacidad. E eso es importante. Porque é um avanço para a discapacidad mental estar dentro, na discapacidad em geral.

Segundo: la discapacidad em si no puede ser ningun motivo de limitação da libertad. Eso es un princípio que está transversal em toda a Convenção. Eu aviso que no programa alguém vai falar com mais profundidade, profundamente, da Convenção, desto. E a coisa interessante da Convenção é que passa da etiqueta à ética. A etiqueta é uma ética chiquita, pequeña. Aos psiquiatras le gusta a etiqueta, a ética pequena. E que é a etiqueta dos psiquiatras? É falar sempre do... Ah, os direitos humanos. Todos falam. Em congresso mundial de psiquiatria, sempre estavam falando de direitos humanos. $\mathrm{O}$ mismo que es un violador dos direitos. $\mathrm{O}$ mesmo que no seu local psiquiátrico viola os direitos humanos. Então, a Convenção está basada sobre o grande slogan do movimentos dos usuários europeus: nada sobre mim, sem mim. Nothing about me, without me. Que acho fundamental. Não podemos falar do usuário sem o usuário. Se o usuário não está, não podemos falar.

Agora, a Convenção tem vários artigos. É uma Convenção grande. Eu chamo sua atenção sobre um artículo, o artículo 14, que é um artículo muito discutido, controversial. Pero lo interessante, lean lo que está em rojo. Que dice? Dice que el ejercicio de la capacidad jurídica respete los derechos, la voluntad y la preferencia de la persona. $\mathrm{O}$ sea, no hay ninguna razón por, al ser discapacitado, la voluntad, la capacidad jurídica da pessoa com discapacidad sea disminuida. No capítulo... No artículo 15 se habla de... La Convenção defende as persona para que no sean sometidas a torturas, tratos o ofensas crueles, inumanos o degradantes. Muita gente diz: mas o que é eso? Parecen que los hospitales psiquiátricos hacen tortura. En el language da ONU, en el language jurídico da ONU um maltrato a um paciente é uma tortura. Está dentro da categoria tortura e trato inumano. Entonces a psiquiatria está aqui. Está. O artículo 19, fundamentalmente, que diz? Diz que a gente tem que estar donde quer. Que se quiere estar na comunidad tem 
direito. E tem direito de estar na comunidad com o apoio. O apoio: a moradia, a vivenda, a alimentação, o trabalho, inclusão social. O programa do Braços Abertos.

O que é o programa do Braços Abertos? O programa do Braços Abertos é permitir à gente de viver na comunidade e não estar dentro do local de psiquiatria ou no cárcere. E com una prestação social. Esto no é um movimento da luta manicomial do Brasil. A psiquiatria diz que é de Trieste. Esta Convenção é de Naciones Unidas. E se o governo de Brasil viola esto, não viola la Lei de Trieste. No está violando la Lei de Tykanori, la Lei de Pedro Gabriel Delgado, ou de Domingos Sávio do Nascimento. Está violando uma Convenção firmada pelo governo do Brasil. Porque la história da saúde mental e de la discapacidad mental severa é uma história de negação. No Brasil, o hospital psiquiátrico é uma cidade inventada; é uma cidade artificial, islada da comunidade. Pero la desospitalização selvage - que passou em vários países - fué na outra forma, de una otra respuesta de delegación do problema por lo abandono, por la carga familiar, sin preocuparse da carga sobre a família. Ou todo lo que es o homeless, os sin lugar, la gente que vive na área metropolitana de Paris, que vive nas calles de Nueva York o que vive dormiendo em São Paulo, en la calle. Eso está otra. É una delegación. Porque é una replicação do manicômio difundido. És un manicômio diluído. A metropolitana de Paris es un manicômio. Tem a misma regla: violento, no tem regla, abandono, tristeza. O hospital psiquiátrico horizontal. E finalmente el truco, o truque, a astúcia que fué la... Que passó en vários países. También na Itália passou esse caso. Muito passou em Espanha, que é a transinstitucionalização. Ou seja, eu cerro o hospital psiquiátrico que se chamava Hospital Psiquiátrico Santa Maria e abro uma vila para idosos com problemas mentales que se chama Santa Luíza. Também. Tudo igual. Um manicômio e outro. Mas um se chama mais manicômio e outro se chama Manicômio Santa Casa. Não também. Eso? Quatro fenômenos. O asilo, a desospitalização salvage, o abandono na calle e la transinstitucionalização são cien años de história de não resposta à discapacidad mental severa. Eu creio que uma coisa interessante - sobretudo para gente mais jovem - por que o Brasil e muitos outros han decidido de empezar um processo de desinstitucionalização? Manicômio é malo, é terrible. Es muy util. Tratar de pensar: por que a gente institucionalizou pacientes? Porque não é uma história de monstros, a história da psiquiatria. Se eram monstros ou se eram exclusivamente monstros, não haviam utilizado as melhores parques e vilas de las cidades de Itália. São manicômios que estão em lugares lindos, bonitos. E por quê? Porque havia uma intenção, padrão opressivo, repressivo, de ser violento? Mas havia uma intenção e um desenho ... Protección, proteção largo plazo para gente desprotegida. Assistência, dar comida, alimentação. Dar de dormir. De comer. Cuidado de largo plazo, cuidado con gran question: cuidado, 
que clase de cuidado? E alívio de la família. Porque é interessante analisar esos quatro elementos que justificam la institucionalização. Porque quando nosotros queremos cerrar um manicômio, queremos seguir protegendo a largo plazo sim. Queremos garantizar assistência en largo plazo sim. Queremos oferecer cuidados de largo plazo sim. Queremos aliviar a família sim. Pero sin muros. Sin institución. O sea, tenemos que guardar las razones profundas da la institucionalização e programar una psiquiatria que garantize esses cuatro elementos sin necesidad de una institución. Por eso se empeza o processo de desinstitucionalizar. Porque os usuários tenian cúmulos de sintomas de déficit, com maior discapacidad de vida no manicômio, mais aislamento social, que aumentava a desvantagem social. La baja calidad de los cuidados, las violaciones de los direitos humanos, la baja efectividad. O sea, um manicômio alto costo e muy baixa efectividad reabilitativa. Não reabilita para nada. E una tremenda insatisfação do usuário. O usuário não estava contento. Então estas, que ustedes conocen muy bién, que son las razones para que justifiqem a desinstitucionalização tem que no olvidarse qual foi la razón para institucionalizar a gente. Porque se usted cria un servicio na comunidade que no es de largo plazo e es de corto plazo, que está funcionando três horas por dia, que no está garantizando o alívio da família,que no está garantizando a proteção da vulnerabilidade e assistência ao paciente, usted está sendo um serviço comunitário de péssima calidad. Esta es la importancia. O sea, a desinstitucionalização no es solamente reduzir camas. No es solamente cerrar hospitales.

No es solamente aumentar altas de hospitales. Es un processo de empowerment de las personas con discapacidad mental. É a construção, de sua inclusão social, de sua cidadania. Não é um processo de engenharia institucional. Cerro, abro. Abro, cerro. Cerro, abro. Eso es parte. Pero no es. Es una cosa más... Más complicada. A terceira conectividade é la relação, conexão entre a reabilitação e reorientação do sistema de saúde mental. A reabilitação psicossocial não é uma técnica: aprender o paciente a cantar, a desenhar, fazer escultura. Não. Isso não é reabilitação. Essa não é a reabilitação.

A reabilitação, o processo de construção da cidadania é uma reconstrução do poder contratual do usuário, que tem implicação em uma modificacion radical do sistema de saúde mental. Se a reabilitação es um ateliê, um laboratório de pintura, eso não vai modificar o sistema de saúde mental do país, ou do estado ou da cidade. E eu sempre digo uma coisa - eu pido desculpa para os que... la escuchada - pero no puedo renunciar a decir que eu nunca vi. Porque además da desgracia que uma pessoa tem, que é de ser esquizofrênico, tem que ser também: artista, cantante, poeta, pintor. Por quê? Por quê? Tenemos que celebrar la santidad, la sacralidad da vida cotidiana. Vocês são todos pintores, 
cantores, escultores? Não. Quando vai na casa essa noite com a sua companheira, com o seu companheiro: quero expressar-me. Se senta, mira a televisão, toma una caipirinha, fala com um niño. Por que o paciente não pode terner eso? Normal. Não. Tem que ser... Tener una coral... É.

Entonces, a forte conectividade entre a reabilitação e câmbio do sistema de saúde mental. Porque a discapacidad mental es una condição crônica que requer cuidados de largo plazo. E en los cuidados de largo plazo está la diferencia entre institucionalizar e desinstitucionalizar. Donde ocurre? Ocurre en el contexto comunitário. Entonces, la desinstitucionalização es desospitalização sim. Pero es garantir cuidado de largo plazo dentro de um local comunitário, dentro da comunidade mesmo. E eso no ocurre. No ocurre principalmente porque la asignación de recursos no corresponde a la necessidade. La asignación es insuficiente, poca plata. E la asignación es ineficiente. La carga. La carga de la enfermedad mental comparada com la carga de todas las otras enfermedades existentes no mundo: câncer, cardiovasculares, diabetes, malária. La contribuição de la enfermedad mental es 13,14 , hasta $15 \%$ de toda la carga de discapacidades. Pero, el promedio, la asignación de recursos à saúde mental, en el promedio mundial es 3\% do orçamento de saúde. O sea, para tratar o $15 \%$ te doy 3\% do presupuesto de saúde.

Claro, com diferença importante. Esses são quatro situaciones. Esta é a classificação do Banco Mundial. Tem no link a la esquerda (slide), son los países de muy baixo ingreso: Haiti, Honduras. São país low midle; low midle quer dizer país como pode ser Jordânia. Pode ser países asiáticos como Sri Lanka. Hacia la direita (slide) hay os midle line, que é onde cabe o Brasil, a Índia, a China, que estão na terceira à esquerda, hacia la direita. E à direita extrema (slide) estão países muy ricos: Suécia, Noruega, Austrália, Canadá. E vocês veem toda la coluna amarelo mais... Amarelo mais rojo? Dice? Vermelho. Vermelho. Vermelho mais amarelo es lo que en el sobre los dólares para la salud, en general. El amarelo é la parte de dólares para salud mental. Entonces veam que en os países muy pobres la parte de dólares de salud que van para saúde mental es 1.5\%; 2.7 nos países mais ricos. Nos países como o Brasil é três punto algo. E nos países muy ricos é 6.8. Com diferencia importante, Inglaterra, por exemplo, gasta, en el mundo o que mais gasta , 14\% do presupuesto de saúde, na Inglaterra, é para saúde mental. Então, uma inversão importante. Pero lo que es interessante es que no es que los pobres tienem menos. Los pobre tienem muito menos. Porque la cantidad de dólares en la primeira coluna (slide), son pocos dólares. Entonces, el 1.5\% de poco. Mientras que en la coluna de direita es $6.8 \%$, é $6.8 \%$ do muito dólar. Entonces é o 6.8 de muito. E muito mais que o 1.5 do muy poco. 
Entonces la información que tuvimos desta transparência es que no solamente hay poco dinero para la salud mental. Mais o país pobre, mais pobre es a inversão em saúde mental. Ineficiência e no solamente. En nosso também hay insuficiência. Hay poco dinheiro. É como decia um amigo mio, economista, em uma conferência en Oxford, que causou muito escândalo. Ele é um economista e dijo: os psiquiatras no solamente son pobres. Reciben poco dinero. Son também cretinos. Porque o poco que reciben lo gastan muy mal. $62 \%$ do gasto de saúde mental no mundo se vá para casas psiquiátricas e manicômios. Solamente $20 \%$ se vá para hospital general, para camas psiquiátricas en hospital general e solamente una pequena parte se vá para estruturas residenciais comunitárias, casas de medio camino. A proposição da OMS e da OPAS é de invertir a pirâmide. A OMS recomenda que os $62 \%$ do presupuesto de saúde mental no sea para manicômios e sea para atencionar a comunidade ou residências protegidas. Mientras que solamente el 15\%, $12 \%$ se vá para manicômios.

Exatamente lo que Brasil hizo. E eu digo: segan sendo orgulhosos. Sean orgulhosos. Brasil es el único país no mundo que ha tenido a inversão do gasto. Há um momento del año 2000, aqui están los grandes chefes da saúde mental do país. Todos aqui sentados na primeira linha. El año, que no me acuerdo, 2005 me diz o Pedro Gabriel. 2005 o gasto da saúde mental no Brasil para manicômio está menor que o gasto de saúde mental do Brasil para atenção comunitária. Único país en el mundo que hubo esta inversão. Ustedes tem que defender esta inversão. E temo que vá tener una luta muy dura para que essa unicidade do Brasil. Que o Brasil é um modelo de referência para a OMS. Porque a OMS não pode tener Trieste como modelo. Trieste é uma cidade de meio milhão de habitantes. O Brasil es um continente. À China lhe interessa saber que passó em Brasil. $\mathrm{Na}$ Índia, está interessada que um país grande como o Brasil tuvo a capacidade de hacer una reforma. Se vocês perdem essa unicidade, de ser o país modelo para a OMS, desastre. Enonces hay que hacer una luta muito dura para defender essa unicidade, que para mim foi um privilégio. Eu venia a Brasil e voltava a Ginebra, à OMS e mira: esta é a referência. O sea, é una coisa importante.

En realidad, donde está el recurso? Donde está el dinero da saúde? Está en los hospitales psiquiátricos. Está en unidades especializadas que não têm área geográfica de captação definida. Eso es típico de muitos países de América Latina. Que hay un hospital de referência super sofisticado na capital, onde está um professor catedrático de psiquiatria. Que não tem nenhuma área de captação. Toda gente, de todo país quiere ir a esse hospital. Pois está o grande gênio. O gênio do eletrochoque. É. Ou la plata está em instituiciones privadas com o sin ajuda de governo, de la autoridad. Entonces hay 
errores sistêmicos, que son errores sistêmicos en el sentido epidemiológico, que recurre no sistema. Primeiro: hay demasiados hospitales psiquiátricos. Esse é um diagnóstico da OMS, no do senhor Saraceno. Hay demasiadas camas en los hospitales psiquiátricos. Que son dos problemas diferentes. Hay demasiados hospitales y hay demasiadas camas en los hospitales psiquiátricos. Hay un rechazo sistemático de las camas psiquiátricas en los hospitales generales. O sea, en algunos países ainda é uma solução importante também. Hay la falta total de soluciones alternativas para usuários de larga instância. Hay insuficientes centros de saúde mental na comunidade. E hay insuficientes conocimiento, formação e integração de saúde mental dentro da atención básica, dentro da atención primária. Atención primária sigue sendo muy poco preparada em trabalhar a saúde mental. E a saúde mental está desintegrada dos centrosbásicos.

Eu recordo o (.......) do David Capistrano, quando trabalhava com a medicina família. Então, integrar saúde mental dentro deste tipo de família. É uma coisa genial. Tem que estar muito difundido no país. Eso é um modelo de referência de saúde pública. Termino a minha conferência - tenho por 10 minutos - com um exemplo interessante: em 2015 eu fui invitado como consultor, como assessor para apoiar uma conferência de ministros. Vinte e quatro ministros de una parte del mundo que ustedes van ser surpreendidos, porque teníamos asi una ideia desta parte del mundo solamente ocurren coisas terrível. Pero no solamente cosas terribles. Eram os Países Árabes, 24 ministros. Estava Iraque, estava Síria, estava Jordânia, estava Palestina, estava Egito; 24 países. Na região da OMS incluía também o Paquistão, Países Árabes, digamos. Esos ministros convocaram durante - eu não estava - convocaram uma semana de intenso trabalho de um grupo, do grupo internacional, (...) para gerar recomendações(...). Esta recomendação que vou mostrar são recomendações de ministros. E não recomendações de espertos. Ou seja, os ministros assumiram e a linguagem que utilizam é impressionante, é uma linguagem inabitual. Vamos ver... O ministro disse "devido a que grandes instituições psiquiátricas tendem a oferecer serviços de baixa qualidade". Isso é uma afirmação importante. "Devido a atenção especializada com serviços na comunidade é mais efetiva se comparada a atenção prestada instituições centralizadas". Se reconhece que o modelo de atenção comunitária é mais [custo efetivo] devido a que existem intervenções custo-efetivas, que podem ser prestadas por não especialistas, estamos falando de países em que existe um Psiquiatra por quatrocentos mil habitantes. Ou seja, não há psiquiatras. Então há problema do ... ou seja, utilizar pessoal que não seja pessoal especializado para fazer psiquiatria. Então, essas são as três afirmações sobre as quais esses 24 ministros embasam sua política comum. Esse [...], dizem os ministros. 
Uma: integração mental em Sistemas de prestação de saúde.

Dois: [desarrolhar] a tensão na comunidade buscando alianças e sinergia de recursos, nesse caso uma linguagem nossa do movimento.

Três: estabelecer camas em hospitais Gerais como parte da saúde hospitalar. Reduzir e reformar hospitais psiquiátricos, melhorar a qualidade, racionalizar a utilização de recursos humanos e financeiros, sacar dinheiro.

Eu comecei a minha carreira em mil novecentos e noventa e cinco e o meu problema era convencer a sua excelência o senhor Ministro que havia manicômio. Ora, hoje em dois mil e quinze o problema não é convencer o ministro a cerrar manicômio, o ministro já sabe, o ministro já quer cerrar manicômio. É “como fazer". Ele quer a tecnologia para fazer. Não há que convencer que é melhor fazê-lo, há que convencê-lo que se pode fazê-lo. Como se pergunta aos ministros?

Primeiro: desarrolhar recursos humanos capacitados em Saúde Mental. Há um desafio, inovação de recrutar e capacitar recursos humanos. Mensagem importante: Paramos com cursos de capacitação que não tem nenhuma efetividade. Quando a gente não sabe (...) um curso e quando a gente está deprimida vai ao curso. Quando o professor não tem (...) reformado, é o professor do curso. O impacto é zero. Eu tenho experiência de curso do uso racional dos medicamentos. Se você quer ter o uso racional dos medicamentos não é o curso, é com supervisão, é com apoio de pessoas. É uma coisa muito mais sofisticada, é a supervisão e apoio, agente de supervisão primária. Não são ninhos que necessitam cursos, são colegas que necessitam apoio. É muito importante.

Segundo: empoderar ministros, empoderar usuários e família, nas ações de saúde mental. Desafio, estigma, discriminação entre profissional de saúde mental e profissional de saúde e a população em geral. Terceiro: o pressuposto tradicional e, claro, os ministros falam de pressuposto tradicional porque nossos economistas injetaram esta ideia. Para superar o manicômio ao momento em que eu gasto é [doble], você está financiando um sistema novo. Então é a fala de um pressuposto tradicional [que há um momento] e tem um problema delicado politicamente porque necessita o gestor e o político uma visão que saia do período eleitoral. (...) Nós temos calculado com economistas que os países que utilizaram mais tempo, foram 17 anos para passar de um sistema, passar do manicômio ao sistema de serviço de saúde mental comunitária então o gasto transacional durou pelo menos 10 anos. Há países em que foi mais rápido, é interessante ver, foi muito rápido a transição na comunidade, durante um tempo estava pagando o manicômio, estava pagando o centro de saúde mental da comunidade. Durou dois, três, quatro, cinco anos 
e depois o pressuposto estava somente em Saúde Mental comunitária. A que se fazer cálculos que o ministro entende. (...)

Quinto: superar a existência do hospital geral frente a [cama] psiquiátrica. há que ter uma negociação, para que o hospital geral (...) Oferecemos coisas importantes, o mundo da saúde geral em hospital geral.

Sexto: a questão de estrutura residencial de trabalho protegido e de apoio da família. É um desafio ... educação, alianças na comunidade, não se pode fazer a reabilitação comunitária sem alianças com outros setores da comunidade. A psiquiatria sozinha não vai encontrar todas as soluções. E finalmente o número sete: reformar, reduzir os hospitais psiquiátricos, melhorar a qualidade e o respeito pelos direitos humanos, cumprir com a convenção, os ministros de países árabes cumprir com a convenção, e desafio e resistência por parte dos profissionais, psiquiatras fundamentalmente, dos políticos, da organização familiar.

Eu tenho um exemplo da Argentina, o exemplo da Índia, o exemplo do Egito. Nos últimos cinco anos esses três países têm proposto lei de reformas de saúde mental avançadas, progressistas. E nesses, a sabotagem sistemática foi feita pelas associações psiquiátricas nesses três países. Na Argentina a lei de reforma da saúde mental foi aprovada pelo governo e a oposição. Eu fui ao parlamento falar em nome da OMS.

Essa lei é boa ( .... ) com esses juristas, todos. O único, porém, ... que não, que a lei era mala, que a lei autorizava psicólogos a ter mais importância, uma coisa delirante, e não psiquiatras solos. E foram derrotados ... Na Índia a lei ... está de acordo com a lei, mas queremos que haja um artigo que diz que o eletrochoque sem anestesia está autorizado. Porque, se não há anestésico, como fazer? Terceiro, Egito, com Mubarak, ditador presidente, um diretor de saúde mental no Egito que (...) as mulheres ou homens com hospitalização voluntária, compulsória, compulsiva...compulsória necessitam do certificado médico. A mulher simplesmente se fica, se o marido, o padre e o irmão diga: "está louca".

Segundo avaliação da qualidade dos direitos humanos no manicômio feita por psiquiatras do mesmo manicômio. Ou seja, eu me auto avalio. Digo: "não, aqui não há violação. Tá tudo bom”. Esses dois elementos, esse psiquiatra [no Egito] O doutor Nasser Losa foi à OMS pedir ajuda para mudar esses artigos [que são uma vergonha]. Apoiamos, ajudamos, e os artigos foram eliminados. As mulheres têm o mesmo direito que os homens de ter um certificado médico e para visitar manicômios e avaliar violação de direitos humanos há uma comissão externa que não tem conflito de interesses na avaliação. 
O Mubarak, na revolução do Egito, a Associação de psiquiatras do Egito disse: "Esta lei foi aprovada pelo ditador Mubarak.

Nós que somos democráticos rechaçamos essa lei aprovada pelo ditador e queremos reintegrar os dois artigos.” Foram reintegrados. E o que quero dizer? ... Eu visitei noventa países durante meus vinte e cinco anos como diretor de saúde mental da OMS, o obstáculo maior a reforma não são os ministros, não são os políticos, são os psiquiatras. Isso ..., e essa interessantíssima (...) de decisões tomadas por ministros me fazem concluir a minha conferência dizendo que os ministros são mais progressistas do que os psiquiatras.

Obrigado. 


\section{Mesa redonda - Reforma psiquiátrica no Brasil: avanços e desafios}

Coordenação: Prof. ${ }^{a}$ Dr. ${ }^{a}$ Fernanda Nicácio. Terapeuta Ocupacional, Professor Doutor do Departamento de Fonoaudiologia, Fisioterapia e Terapia Ocupacional da Faculdade de Medicina da USP

\section{Prof. ${ }^{a}$ Dr. ${ }^{a}$ Ana Maria Fernandes Pitta}

Médica, Psiquiatra, Professora do Departamento de Medicina Preventiva da USP (aposentada), Professora Adjunta da Universidade Católica do Salvador/UCSAL, Presidente do Capítulo Brasileiro da World Association for Psychosocial Rehabilitation, Ex-Coordenadora da Área Técnica de Saúde Mental do Ministério da Saúde do Brasil.

É um prazer imenso olhar essa sala toda colorida e já fazer uma certa observação feminista, feminina e médica. [Risos]. Contra qualquer cismo. Viu, Fernanda Nicácio? Você que é professora da Faculdade de Medicina da Universidade de São Paulo. Mas olha, é um prazerimenso.

Eu lamento que Sônia não esteja aqui por que eu iria fazer a primeira referência a ela própria. Sônia é uma mulher que é baiana aliás, vivemos a primeira infância no mesmo Largo do Pelourinho. Mas eu a conheci em São Paulo, quando começamos uma guinada da política de saúde mental nos anos Montoro e Sônia foi uma companheira, junto com outros, alguns eu identifico aqui, que puderam, na elaboração daquela cartilha de saúde mental, romper com a hegemonia e aí sim, uma hegemonia psiquiátrica absoluta. São Paulo tinha o maior contingente de leitos psiquiátricos no país, a maioria lucrativa à indústria da loucura. (Deixa eu pegar aqui o meu relógio, para ajudar.) Então, ela está aqui... como, também, eu acompanhei meu querido Pedro Gabriel, os primeiros três anos, no Ministério. Mas, foi fundamental ter Sônia Barros, não é? O então secretário da SAS, o Renilson também, cuidando das possibilidades concretas. Política se faz com ira, amor e dinheiro. E eu acho que a Sônia foi, uma pragmática crítica na obtenção dos recursos que fizeram viável a reforma psiquiátrica brasileira. Eu acho que o Pedro vai poder falar sobre isso também. (Agora, para eu ir mudando isso, sou eu própria que tenho que fazer, não é? Eu não sou boa nessas coisas, mas, vou tentar. Como é que faço? Vou 
passando aqui para frente, é isso?) Então gente, olha eu quero ser a "poeta da esperança". Mas, a gente não pode deixar de falar de muitas perdas e tristezas que a gente experimenta, particularmente nos dias de ontem e hoje. A madrugada de hoje foi trágica, mas, começamos o dia com uma notícia muito triste, eu queria fazer uma referência, eu sou corintiana e realmente a perda de vida de jovens no futebol que talvez seja atualmente a única alegria nacional, não é?

Foi uma coisa difícil, mas, ter aprovada a PEC55, eu localizo como o golpe militar instituído. Porque, para um governo transitório de dois anos aprovar medidas que nos amordaçam 20 anos, a nossa ditadura militar não durou tanto, porque ao final, aproximando-se os 20 anos, a gente já estava no movimento de abertura. Agora a gente prescreve o fechamento por 20 anos. Eu estou bastante paralisada ainda com isso.

\section{[Aplausos]}

Então, eu tenho que falar, fazer algumas referências históricas, não é? Eu passei muito rapidamente pela coordenadoria de saúde mental nos anos Montoro, foi quando eu conheci a Sônia. Depois eu voltei para a Universidade, o Departamento de Medicina Preventiva que teve uma ação bastante intensa na criação do núcleo do [centro] de saúde mental, na vinda e na recepção de todas essas pessoas maravilhosas, inclusive o meu querido Benedetto Sarraceno, que pôde nos ajudar a pensar ideias, a pensar o novo para a cena brasileira. Mas, quando eu estava no Canadá fazendo pós-doutorado, recebi um dia um telefonema que uma outra pessoa muito querida, que vocês vão ouvir falar que é o Domingos Sávio, me convidando para ser coordenadora de saúde mental. Era plena epóca tucana e ele tinha me pedido isso. Mas, como eu tinha ido ao pós-doutorado por um ano, eu tinha de vagar esse meu tempo na universidade e aí, coisas da vida, do amor me fizeram poder me afastar e assumir a coordenação de saúde mental, num contexto extremamente difícil.

Nossa, o meu querido Alfredo Schechtman, que foi valioso na assistência. Aliás, ele chegou a assumir a coordenação de saúde mental para me esperar, não é? E mais umas quatro pessoas. Então era uma coisa pequena, mas, poder ter um certo horizonte nos ajudou bastante. Nos dez anos da lei de saúde mental, passei o título aqui, mas, vocês podem localizar, ele também me recomendou que eu fizesse uma reflexão sobre os dez anos da lei e a reforma psiquiátrica brasileira. E ele chegou a me fazer a provocação, por que nós temos as versões dos cariocas onde, a grande revolução começa no Rio de Janeiro. E eu tenho uma versão também, também firme, que São Paulo é mãe, não é madrasta. Merece voltar a tempos melhores. Você sabe que eu sofro mais com os resultados eleitorais de São Paulo do que Salvador. Por que Salvador não tem muito jeito. Agora aqui não, aqui 
eu cultivo a minha esperança. Então esse trabalho fala do meu modo de ver, por que aí eu descobri isso. Parei de brigar com Paulo Amarante desde que eu descobri que cada um vê o mundo conforme o seu coração, seu olhar, a sua alma e a sua formação. Então aqui tem escrito e o Benedetto, vários amigos comentaram, ele também participou de uma boa coletânea que é um artigo bom, muito bom do Pedro Gabriel.

Enfim, vale a pena para vocês que são estudantes ver esse número que foi lançado em 2012, mas, é um número de dezembro de 2011, justo nos dez anos. A lei só existiu para inscrever o nosso processo de luta. E agora, com essas leis espúrias que a gente está conseguindo produzir para o Brasil, eu temo muito e até briguei, cadê meu querido Tykanori quando ele disse: “Essa lei não agradou a ninguém!". Foi a lei possível, claro que ela começou mais radical, prescrevendo a não existência de qualquer hospital ou leito psiquiátrico e a gente teve de negociar. E, quando eu entro para a coordenação de saúde mental, eu justo entrei acompanhando Paulo Delgado, que vai falar hoje à tarde. Mas, visitei muito senador, muito deputado, ouvi muita baboseira, mas, nada que se comparasse aquela demonstração espetacular do processo de impeachment de Dilma Rousseff e o que é atualmente a composição do nosso Congresso Nacional. Vergonhoso, lastimável, individualista, etnocêntrico que obviamente não é o cenário melhor para avaliar políticas públicas nacionais generosas, universais, solidárias como precisamos para que as coisas caminhem. (Eu estou aqui olhando para ver o tempo) Eu fiz uma certa avaliação que, apesar das condições desfavoráveis, nem sempre trabalhamos em condições favoráveis, aliás, a maior parte do tempo trabalhamos em condições desfavoráveis; mas nós sacamos os serviços assistenciais terapêuticos, os medicamentos psiquiátricos básicos que hoje a gente não tem garantia. Sacamos humanização propostas de hospitais gerais, onde habitualmente a presença de serviços de psicologia e leitos psiquiátricas dos Estados gera uma consequência da discussão das humanizações. E percorremos vários lugares fazendo isso. Claro que assistimos ao longo desse tempo que uma política de álcool e drogas que se instituiu, uma política de, quer dizer, pelo menos propostas mais concretas de infância e juventude.

Mas, eu devo fazer, vocês devem fazer um reconhecimento que tanto Domingos sabe, eu herdei várias coisas dele, inclusive um grupinho na área de álcool e drogas, mas, que nós fizemos um documento, não é? Então, eram pessoas realmente hard, mas, fizemos alguns trabalhos nessa direção. E me lembro com muita gratidão de uma pessoa que, no desespero e numa solidão absoluta do planalto até por que tinham tirado a Comissão Nacional de Saúde Mental do Conselho Nacional de Saúde. E eu, numa negociação extremamente dura com Nelson Rodrigues do Santo, companheiro de partido, voltei 
a reintroduzir, não mais com quinze pessoas porque, estava normatizado que seriam sete ou nove. E aí, por isso, minha amiga Miriam ficou zangada comigo, por que nós tínhamos realmente que restringir mais, garantirmos o retorno da Comissão Nacional de Saúde Mental. Mudamos o número, a reforma psiquiátrica voltou com saúde mental, fruto de intensas negociações para que pudéssemos avançar. Acompanhei nesse período, a lei saiu, já tinha onze anos, quer dizer, ela foi aprovada com doze mais ela tinha onze anos no Senado. E o reconhecimento público, habilidade parlamentar de Delgado para que isso pudesse caminhar. E a lei é homologada pela presidência da República e ela já nasce velha e, obviamente começa a envelhecer, por que leis existem para ser marcos históricos. E se a sociedade avança e se modifica, deve haver mudanças na legislação que acompanhe. O problema é que, a sociedade brasileira avançou, mas, não tanto.

E agora a gente está vendo nesse movimento internacional de 'endireitização' do mundo, o Brasil não ficou de fora. E a 'endireitização' do Brasil nos torna ameaçados de todas as coisas que a gente alcançou. E aí vem a era Pedro Gabriel, dez anos. Sônia Barros junto com ele, todo crescimento da política de saúde mental no país. Mas, políticas consolidadas nas nossas conferências nacionais de saúde mental e aí eu faço uma ressalva de que deveríamos ter investido mais na politização da política. Por que, eu fiz uma observação. Da primeira conferência nacional, que foi uma pioneira, mas, foi imposta, para a segunda, demoramos cinco anos. Daí em diante ele começou a demorar dez anos. E agora já tem seis anos que nós, que acordamos, que deveríamos atualizar esse compromisso não tanto pela força política que nós temos, mas, para que isso fique dentro do coração da gente. Eu gostei daquela conversa, nãoé?

Democracia pela emoção, pelo coração. Para fazer isso eu preciso humanizar a discussão democrática e para humanizar a discussão democrática, é necessário isso, gente. Só se humaniza com humanos. Então, precisamos ter sistematizado encontros periódicos para atualizar e expor nossas ideias, nossos compromissos democráticos. Então, encontrei o Desviati, ele me emprestou um livro e, eu lendo o livro dele fiz uma coisa parecida. O que caracteriza a reforma psiquiátrica e o que podemos perder com esses novos modelos neoliberais que estão franco vigor. Então, de um lado, integração de todos os recursos públicos. Foi isso que a gente buscou, não apenas na saúde, mas, na Intersetorialidade, promoção social, justiça, buscamos integrar os recursos para fazer uma boa política. Nesse momento, está o contrário. Fragmentação de recursos e também do cuidado.

Agora está na moda consultas médicas, plano de saúde acessível, várias coisas que me pareciam caducas, que já não estavam mais em voga, que nós trabalhamos, estudamos 
saúde pública, planejamento, sabemos que não vai dar em nada. Nós não temos condições de oferecer um plano acessível, privado de saúde para 200 milhões de habitantes por essência. Não temos. Mas, é isso que está posto. Por quê? Porque o atual ministro da saúde é absolutamente ligado e eleito por donos de planos de saúde. Três minutos e eu não falei nem a metade. Olha, eu fiz fortalecimento na continuidade do cuidado, até então descontinuidade medicalização e modelos assistencialistas. A menção comunitária para casos severos e persistentes e, em contrapartida o novo modelo está propondo retorno às comunidades terapêuticas, que nada mais é do que manicômios fechados, são instituições fechadas, precisamos deixar isso claro. E mais ainda, obviamente que, para todos os casos é necessário a gente pensar em vários níveis de intervenção. Mas, tudo que é muito grande, a comunidade terapêutica que eu tenho na Bahia tem mil camas. A maioria para adolescentes. É a comunidade do Doutor Jesus, que se elegeu deputado estadual, sargento Isidoro. Então a gente precisa denunciar, precisa falar sobre isso e denunciar, porque o que está realmente em vigor é uma retomada de um modelo arcaico que a gente já tinha avaliado, já atualizamos em todas as conferências e invocando a outra lembrança ótima, Geraldo Peixoto sempre falava com grande força de que não é esse o cuidado que ele quis para o seu filho, não é? Então, para o sonho da cobertura universal, a privatização da área básica.

Como eu serei obediente porque a democracia é a mais bela invenção humana, mas, a mais difícil, eu obviamente vou deixar de lado uma reflexão que continua, recobre participação, autonomia, a gente devia ter feito uma crítica, porque, se a gente assume o recovery, a palavra recovery que está hiper na moda agora no Brasil, nós deixamos de lado até a história do recovery. Eu estive em 80 em Guernavaca, quando homenageamos Franco Basalia que havia morrido, mas, fomos surpreendidos por uma vitalidade incrível dos recoverianos da Califórnia que lançaram seu livro "história do eletrochoque", muito bom e que já trazia a discussão da necessidade de eles serem sujeitos da sua história e subordinarem tratamentos, modelos, injeção a sua discussão. Então, anos oitenta ás vezes ajuda, por que aí você é testemunha ocular. E aí eu não posso deixar de dizer, eu trabalhei com Nise da Silveira, ela trouxe uma forma especial de resgatar sujeitos e história, mas, era uma pessoa com quem eu trabalhei diretamente, eu vi o quanto aqueles usuários, eram usuários.

Na época, eu sou da clínica Dona Delfina, não sou do Botafogo. Então, estou falando da Dona Delfina, da casa das Palmeiras da Dona Delfina, por que aí eu fui brigar com o Eduardo e ele: "Não, por que ela estava no manicômio". Não! Ela estava no manicômio, no Museu do Inconsciente por que também eu acho que, se a alternativa também não é 
botar a banana e abacaxi na cabeça e dizer: "Olha, eu sou alternativo". Ela trabalhou lá dentro, mas, lá dentro ela construiu uma inovação. E lá fora, quando o sistema de saúde era totalmente manicomial, nós chegamos a gastar $97 \%$ dos nossos recursos com hospitais, Nise da Silveira criou a Casa das Palmeiras. Como eu trabalhei lá e criei o primeiro CAPS, posso dizer para vocês que, há muito da Casa das Palmeiras em todos os CAPS e em especial aquele descrito como Jairo Goldberg descreve no livro: "Reabilitação Psicossocial", aqueles que valem a pena, aqueles que fazem o trabalho com e não para, enfim... Embora qualquer que seja o CAPS eu defendo, viu? Por que vocês trabalharam bonito, é melhor um CAPS do que uma unidade de mil pessoas. Então, aí eu fiz uma reflexão teórica, já que como eu falei, sobre o neoliberalismo e a estratégias de vulnerabilização nossa, de exaustão, de cansaço. Nós estamos absolutamente massacrados, mas, não vai dar tempo de falar sobre isso. Ela vai passando aqui, o dia que vocês quiserem conversar sobre isso, eu estou me interessando sobre isso, neoliberalismo e como as formas, as técnicas de poder, não é? A forma de dominação, de exploração, de fazer com que você se sinta culpado e responsável pelas coisas que não acontecem e aí fica com insônia, não é? A indústria da depressão, não é? São coisas que a gente precisa discutir para não sofrer sozinhos e solitários. Aí eu vou passando aqui rapidinho, só com a fantasia de que está tudo passando na cabeça de vocês.

Smartphone, a tirania do Smartphone, não é? Ontem eu estava vendo duas pessoas sentadas e, quer dizer, você não precisa mais olhar no olho do outro, você já não precisa mais. Por que, o panóptico agora é digital, não é? Não precisamos mais ser panópticos, físicos porque nós próprios estamos regulando isso. Assim, eu estou falando todas essas coisas porque eu descobri um cara que vocês devem descobrir também. É um sul coreano que estudou metalurgia na Coréia do Sul, portanto fala aqueles negócios lá, mas, que devia ser maluco porque ele quis estudar literatura alemã. $\mathrm{O}$ nome dele é complicado Byung Chul-Han. Mas, o Han é fácil, $\mathrm{H}, \mathrm{A}, \mathrm{N}$. Já tem um único livro traduzido no Brasil que é "A Sociedade do Cansaço", que fala justo sobre esse nosso sistema de exaustão. Mas, tem a psicologia, política, tem livros.... Eu acho que ele é um cara, ele ensina filosofia atualmente na Universidade de Berlim, na Faculdade de Artes e Filosofia. Então, eu queria só para concluir, fazer um sacolejo. Vocês vão estar com Gastão Wagner, mas, eu vi a distância que eu não pude estar, ele dizendo que tem que sacudir a poeira para sair desse inferno em que nós estamos, porque é fundamental que saiamos daqui construindo esperança, bons acontecimentos. Não vamos nos deixar abater. Não vamos achar que a pior crise, porque isso é mentira. 
Eu, na minha história de vida, já enfrentei crises muito piores, não é? A grande crise que eu estou vendo agora é a crise da ilegitimidade. Nós temos um presidente que não foi eleito para isso, nós temos, não é? Legislações, eles até estão brigando entre si. Ontem, vendo o desastre que estava acontecendo com relação à legislação. Eu até torci lá pelo pessoal que fez o negócio do movimento anticorrupção. Eles quase que perdoaram todos os pecadores para evitar, não é? O que poderia ser visto. Então, existe saída sim. Ao pessoal aqui do Ocupa, quem ocupou a Universidade, quem ocupou escolas, quem ocupou a coordenação de saúde mental, tem toda a minha solidariedade e apoio político, porque realmente em um momento em que a macro política não está sobre nosso governo, que se quer essa democracia frágil do voto, a gente está tendo controle, vamos buscar novamente as estratégias micropolíticas de luta. E vamos apoiar esse pessoal que tem coragem.

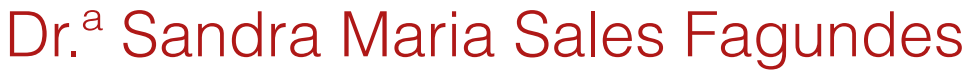

Psicoterapeuta, psicanalista e psicóloga do Governo do Estado do Rio Grande do Sul, Ex-Diretora do Departamento de Atenção Hospitalar e de Urgência (DAHU) do Ministério de Saúde, Ex-Secretária Estadual de Saúde do Rio Grande do Sul, Ex-Diretora das Ações de Saúde (DAS) da SES-RS, Ex- Secretária Municipal de Saúde de Porto Alegre, Ex-Secretária Municipal de Saúde de Viamão, Professora convidada da Maestría en Salud Mental - Universidad Nacional de Córdoba- Argentina.

Bom dia a todos vocês. É uma alegria estar aqui. E a alegria é o que tem nos carecido ultimamente neste período internacional, particularmente, no nosso País. Então, quando a Sônia convidou, imediatamente eu aceitei. E também não foi difícil eu reagir, porque eu sou uma senhora aposentada faz uma semana. Então, aquela última apresentação, psicóloga da Secretaria Estadual de Saúde, é a última vez que eu escuto. Não sou mais! Já estou aposentada e, também, aprecei a aposentadoria em função de todos esses retrocessos que, evidentemente, se avizinham no meu Estado particularmente. Sou funcionária... viu?! Era funcionária do Estado do Rio Grande do Sul. Então, a convocatória é, mais do que nunca, (isso já foi dito aqui) da importância dos encontros, de produzirmos encontros que valham a pena, que façam a diferença. Então, mais do que nunca, nós precisamos buscar essas essencialidades. Não dá para viajar para São Paulo, ou não dá para vir aqui abrir uma agenda, e não fazer a diferença. Não valer a pena. Temos que produzir autoria. 
Mais do que nunca, todos nós estamos convocados a fazermos história, tendo autoria. História é outra indagação.

Bom, antes eu vou falar dos avanços, pois aqui nós estamos diante de gerações novas. Então, assim como o Fidel morreu semana passada e deixou um legado. Nós temos mais tranquilidade em relação ao que vai acontecer na Ilha em termos que continuidade e de garantia de direitos, do que nós temos em relação ao nosso País. Hoje, com todas essas lutas democráticas brasileiras. As gerações que nasceram já no regime da Ilha de direitos e da igualdade com problemas que foram sendo identificados, só alguns resolvidos e outros não, mas todos nós já soubemos os índices de IDH, a baixa a mortalidade infantil, o direito das mulheres ao aborto, as pesquisas, o avanço na saúde. Acho que aqui ninguém tem dúvida do que temos - de avanços e indicadores de qualidade de vida -, que se alcançou na Ilha. E tem uma geração que nasceu assim, pode achar que a vida sempre foi assim. Mas sempre teve o cuidado, de onde a gente conhece, que as gerações tivessem a real noção de como era e como é. Agora passa pelo teste, efetivamente. Bom, aqui os avanços muitas vezes, isto que Ana Pitta diz: olha, já se destinou 97\% dos recursos da Saúde Mental para o Hospital Psiquiátrico, internação psiquiátrica. Isto, para alguns de vocês, pode ser um dado ou pode ser de menor importância. Mas isso exigiu muito trabalho, muita militância, muita direção, de coordenadores de saúde mental, como os que já tinha falado Ana Pitta, Pedro Gabriel, Tykanori. Essa reversão só aconteceu, de fato, em 2006. Um dos nossos professores, o Benedeto Saraceno dizia... Depois eu procurava para pôr na minha dissertação onde é que estava escrito, não estava, era só fala, que o dinheiro tinha que seguir o paciente. Agora pelo menos na minha dissertação está escrito! Em outros lugares também. Diziam: não tem que ficar no hospital, porque não tem onde ficar; não tem família está abandonado; não tem vínculo. Mas lá ele tem casa, tem comida.... Ora o que se faz? Tira-se o dinheiro do hospital e leva o dinheiro para onde o usuário vai. Aí se cria a rede. Mas isso dá trabalho... A lei levou 12 anos para ser aprovada. Naquela época a gente tomava uísque de 12 anos, agora não sei se toma cachaça, um rum, para comemorar os 12 anos. Então, levou 12 anos para ser aprovada a lei. E por que que eu falo da cachaça e se reunir? Porque isso não se faz simplesmente na lógica racional. Sim precisamos dela, mas precisamos de redes quentes, precisamos de amigos. Nós precisamos daqueles que se viram na madrugada. As cartas mais bonitas para o Fidel, foram de pessoas que escreveram: perdi um amigo que eu ligava a qualquer hora da madrugada. Qualquer jornalista; Maradona; Mojica; Lula. Todos disseram: "perdi um amigo que eu podia ligar a qualquer hora". "Marcamos entrevista às duas da manhã, eram seis horas da manhã e nós estávamos conversando". Esta noção, da disponibilidade, da acolhida, nós 
precisamos manter isso vivo. Como é que se faz isso? No cotidiano, nas universidades, no conjunto do trabalho, no dia-a-dia. Como abrir essa disponibilidade? O que nos ajudou? Nunca termos perdido de vista o que nós estávamos trabalhando: era na luta dos direitos, a cidadania, aos cuidados e nas construções de subjetividade. Pessoas com desejo, pessoas que, secularmente, estavam alijadas disso.

Estavam interditadas nessa questão. Então, nós somos dos Movimentos Sociais.

Por que que nós nos destacamos lá na década de 80 , e 90 junto com o MST? O MST, foi o único movimento do mundo que quando tudo se urbanizava, ele voltava para o campo. Isso Sebastião Salgado registrou. Era o único movimento ao contrário da via migratória, reivindicando uma outra relação. Nosso movimento, na sua peculiaridade/ singularidade, também, sempre soube de que lado estava. Na busca de direito e para que servia o ser trabalhador de Saúde mental e operador de saúde mental. Na luta pelos direitos, pela possibilidade do cuidado, efetivamente, em liberdade. De construção de laços para junto a sociedade, que estavam impedidos. Isto deu sentido para gente. Não é ao contrário! Porque hoje tem, CAPS, tem cooperativa, tem Centro de Convivência, tem atenção básica, tem apoio matricial. Tem uma série de dispositivos e serviços, que podem constituir a Rede. E a gente achar que o usuário tem que passar por tudo isso. $\mathrm{E}$ não é verdade! Não é assim, necessariamente. Nós não podemos perder a relação ética, política, com quem é que nós estamos trabalhando. Se a necessidade deles, de identificar laços social e vida, passa por convivência, passa por trabalho, passa por escolarização, também, que bom que tem um cardápio disponível, que a gente pode a recorrer. Mas não obrigar o usuário seguir um roteiro rígido na vida, pois nós vamos estar reproduzindo o manicômio. Todas nós sabemos disso! Nos CAPS, que é o melhor CAPS do mundo - lembrando o Marcos Vinicius - o pior CAPS é o melhor do que o melhor hospício. Então, nessa direção, mas dentro do nosso cotidiano e ao falar de Micropolítica, e isso faz sentido, falar da Macro e Micropolítica dos nossos serviços. Se nós olharmos os planos terapêuticos dos singulares eles existem efetivamente ou não? Eles efetivamente seguem as necessidades dos nossos usuários ou não? E nós identificamos permanentemente que não! Como tem disponível um que canta, tem outro disponível que dança, tem outro disponível que é artista. A gente faz o usuário participar automaticamente disso como um robô e reproduzimos a mesma alienação anterior.

Um pouco melhor, vamos dizer, para o lado adaptativo, mas não para o lado libertador. Então, essas questões em relação isto nós precisamos manter vivo, isso é se fazer encontros. E aí tem algo que nada nos tira. Não tem ditadura que nos tire! O nosso exercício profissional, depende exclusivamente de nós. Se estamos na rua, estamos na 
linha do metrô, no ônibus, onde nós estivermos, este encontro, o olhar, o bom dia, a boa tarde, o pegar no braço, o ser carinhoso, ser respeitoso, depende exclusivamente de nós. Essa é uma preciosidade e é um tributo de quem trabalha com saúde, de quem trabalha com os humanos, nada nos tira. Se nós temos a possibilidade desse encontro, nós temos muita autonomia nesse encontro: de gerador de poder, de gerador de novas realidades, de novos encontros. Então, isto nós precisamos cultivar. Nós precisamos manter essa questão, onde nós estivermos. Agora, onde nós estivermos e esse é o nosso tormento. Um de nossos tormentos atuais, é que toda essa Rede, toda esse investimento de recursos, sim corre risco! Esta Rede que, muitas vezes, nós já antecipamos e dissemos que éfrágil.

Esta rede que tem profissionais de saúde, não em número suficiente, se sente sobrecarregados e que há necessidade de ampliar espaço de processo de trabalho e de diversificar as equipes de incluir informação. Esses continuam sendo nossos desafios, que a formação transdisciplinar, interdisciplinar nós vamos efetivamente produzir em território? Que tipo de pesquisa ou que tipo de investigação fazer? Ainda, quem faz pesquisas em território multiprofissionais é considerado multicêntrico? Ainda, quando fazem intervenção. Ainda é considerado, não ciência, ou não professor Universitário sério de verdade. Tenho uma amiga, encontrei com Sergio na vinda para cá, que faz trabalho desmedida lá no Rio Grande do Sul, e encontra o professorzão, sabe? Disse: não sei porque vocês ainda fazem isso? Quando é que você vai ser professora Universitária? São professores, e fazem aquelas publicações tipo A. Eu não sou professora. Tipo A, que faz publicação A, que tem progressão, que já tem herdado todas as progressões, que faz toda a burocracia que a Universidade exige da carreira. Eles olham com desdém, para quem faz pesquisa ação, para quem faz pesquisa intervenção, para quem faz pesquisa viva em ato. Também aí, e esse é um dos avanços, em 87 . Nós não tínhamos ninguém na Universidade. Jurandir Freire era o nosso ídolo. O Benilton, o Birman, o Grupo da UERG, eram eram algumas das referências, felizmente, que a gente tinha. Nós líamos os mesmos livros. Hoje, felizmente, não é assim. Muitos de nós estamos na produção e não perdemos esse vínculo ético-político da transformação da realidade e de políticas públicas. O outro avanço, não há menor dúvida, que o empoderamento dos usuários é um fato.

Eu fui na apresentação de mestrado em saúde mental, em Córdoba, e não encontrei essa marca de participação dos usuários, na Argentina, e vários países na Europa, também, tem dificuldade de promover essa participação. A participação com autoria. Semana passada, retrasada, nós estávamos na discussão do "Ouvidores de Vozes", que alguns aqui já conhecem, quando os usuários falavam, eles diziam, mais de um: "Olha, 
a minha loucura (ouvir vozes), sim, me gerou sofrimento. Mas, graças a minha loucura, eu tô aqui falando. Eu aprendi a falar. Antes, eu não sabia falar e, se não fosse isso, eu não conseguiria falar". Então, positivou algo que tinha que ser invisível, escondido, que gerava vergonha. $\mathrm{O}$ fato dele lidar com as suas próprias vozes, com a sua loucura, depressão e numa relação de respeito, de construção, de sujeito, permitiu que ouvisse a sua própria voz e começasse a falar sem vergonha. Então, o desavergonhar ainda está presente. Também, eu tive um orgulho novo, em Alegrete, que é 4 mil, 5 mil pessoas, desta vez foram 2 mil pessoas. Nós tínhamos perdido as eleições, nós estamos nesse período todo, e foram e uma das questões que as pessoas dizem dos usuários, dizem é perder a vergonha. Não ter mais vergonha da minha loucura da minha cabeça, o de pensar diferente.

Aqui nos braços abertos, de São Paulo, uma das situações que a Romena conta, um morador estava num Hotel antigo, não levava o familiar, mudaram para um Hotel mais adequado, melhor, bonitinho e bem arrumado. E ele trouxe a família e ele disse que "antes lá eu tinha vergonha de levar, aqui eu não tenho vergonha”. Então, opera essa lógica ainda entre a população que trabalhamos e precisamos trabalhar, na produção de subjetividade, rompendo com isso. Nós emprestamos o uso, nós precisamos oferecer nosso corpo, oferecer a nossa cabeça, oferecer a nossa prática, o nosso pensamento, o nosso conceito para essa transformação, para ter outro corpo, de outra pessoa, de outra subjetividade. E isso, nós precisamos aprender a fazer. A gente não nasce sabendo e muitas das nossas formações não nos levam a isso, ao contrário disso, que não se pode fazer isso. E o que nós estamos fazendo é sem esse uso não há travessia, não há essa produção efetivamente de futuro. Já está acabando o meu tempo. É uma das questões que aparece, do autor coreano, que ele nos traz. E aí vem esse tema de como é que a gente dialoga com quem que a gente está pensando e como. Nós temos que ter a capacidade um tema de complexidade, de que nós temos uma lógica de pensar que é continuidade, que é história que é vínculo, que é uma lógica de pensar o mundo, distinta do que é hoje o mundo. Este, da conectividade que o mundo hoje está vivendo, e a tese dele, é que não há aceleração do tempo, que o tempo que houve foi fragmentação do tempo. E o que se tem são poucos e que não tem continuidade. Então, o que tem e uma para dar um exemplo, ele diz, "uma coisa é experiência e experiência exige tempo contínuo" daí a experiência, nós sempre falamos da experiência da doença, da experiência do sofrimento, e daí aprender a lidar, e essa são as categorias que nós estamos trabalhando.

Agora, existem gerações e, hoje, uma cultura que não tem experiência. Ele fala em vivência instantânea, não tem memória, não tem atenção, não tem continuidade. Então, isto pode nos ajudar a entender algumas coisas, como por exemplo: combinam 
pelo Facebook e milhares de pessoas vão protestar na Paulista. Depois no dia seguinte, para ir votar, não vão votar em quem propõem direitos e igualdade. Porque são outras lógicas. Se nós não entendermos que existem outras lógicas de estar no mundo, de pensar, de ter autoria. Nós não vamos chegar com as nossas categorias antigas, que ainda vale e na construção do sujeito, mas não são suficientes. Nós precisamos hoje, não são só os nossos usuários, nós trabalhadores, ou nós que já somos jurássicos e já fizemos história, estamos questionados nos que nós construímos e o que que é que nós temos que continuar fazendo para continuar vivendo e produzindo vida. Muito obrigada!

\section{Sônia de Fátima Rosa}

Presidente da Associação Mente Ativa de usuários e familiares de Saúde Mental de São Bernardo do Campo - SP.

Bom dia a todos! Eu sou a Sônia ou Soninha, como minha mãe me chamava. Hoje eu ainda, sou lembrada no conselho municipal de saúde em São Bernardo, além de ser da associação. Em 2017, passarei a ser representante da associação no conselho. Eu sou uma ex-paciente de manicômio. Puramente, aos 18 anos, meu pai teve óbito em 15 dias dentro do Lacan (Hospital psiquiátrico) que ainda resiste e insiste em permanecer no município. São Bernardo já não interna mais. Mas aí, o choque foi grande.

Eu trabalhava. Eu estudava. Estava fazendo técnico de administração. No fim de semana, eu ficava com algumas crianças, que eu participava de uma comunidade voluntariamente. Eu contava estorinha, brincava e passeava. Enfim, eu gostava de estar junto ali. Comunidade de jovens que eu interagia também. Essa notícia sobre papai, me deu um tranco. Foi muito duro e eu não conseguia melhorar dessa perda. Eu fui enfraquecendo no trabalho. Não queria nenhum tipo de relacionamento, chorava muito. Sempre aos cantos. Não consegui me limpar direito. Aí disse que precisava procurar um médico. Eu fui ao clínico e pedi para passar com psicólogo. Ele respondeu que iria me encaminhar para uma consulta com o psiquiatra e aí ele vê esse psicólogo para você. Eu disse está bem. E fui, mas não com a firmeza que estou hoje. Eu estava muito malzinha. Então, chegando ao psiquiatra, no antigo ambulatório de saúde mental de São Bernardo do Campo, ele começou a falar comigo. E no fim, ele disse que meu caso não era para psicóloga. Era caso medicamentoso. E aí, saí com uma sacola de remédios: Haldol e Akineton. Aí eu fui embora para a casa com aquela sacola. Eu gravei os nomes dos remédios, porque o tempo 
passou e só me davam isso. Isso não me tratou e nem me destratou! E de vez em quando dava uns repuxes, que mais tarde eu aprendi que era reação extrapiramidal. Só que os médicos não falavam nada disso e continuavam a me passar sacolas dessas medicações.

Era manhã, tarde e noite. O médico mantinha a dosagem e não se preocupava em saber como eu me sentia. Se eu dormia ou não. Se eu chorava ou não. Se comia ou não. Nenhuma pergunta. Apenas prescrevia o mesmo medicamento. Isso foi me destratando de tal modo, que foi necessário me afastar do trabalho. Precisava que alguém me acompanhasse. Falei isso a ele e a resposta foi: não, é isso mesmo. As consultas, sempre eram muito rápidas. Mal olhava para mim. Até que um dia ele disse para eu ir fazer uma consulta no hospital. Minha mãe me levou e foi a mesma coisa que aconteceu com meu pai: me internaram e disseram para ela: daqui 15 dias você poderá vir visitá-la.

O problema que com meu pai foi a mesma coisa e depois de 15 dias, quando fomos visitá-lo, recebemos a notícia que ele foi a óbito. O que foi um choque, porque ele veio de cabelo raspado, parecia que tinha alguns hematomas no corpo, alguns sinais de maus-tratos. Então, depois que entrei naquele hospital, a primeira coisa que levei foi uma injeção que me fez cair no corredor. Depois me arrastaram para um quartinho chamado quintelha, um quarto forte. E no chão eu fiquei, sem saber quantos dias se passaram. E num determinado dia, abriram uma portinha e colocaram um pratinho de comida.

Gente! Aquilo é absurdo, por ali você condiciona uma tortura. Hoje eu sei falar que é uma tortura, mas, na época, não entedia. Aí, de repente, chegou um dia que me falaram que chegou minha visita. Foi assim, a tortura, até o dia da minha visita. Depois, passou para os eletrochoques. E assim foi indo... torturas e eletrochoques. Contenção na cama. Ganhava maus-tratos. Eu falava e era ignorada. E mais tortura vinha para mim e para os outros. Eu via de tudo ali. Pessoas muito debilitadas, a ponto de não conseguir comer. Todos estavam uniformizados. Afinal era a primeira coisa que faziam: tiravam a sua roupa e seus pertences e lhe colocavam o uniforme. Corredores enormes, com teias de aranhas para todos os lados. Um pátio para você ficar. Você vai ficar ali, independente se está dopado ou não. Se tem condições ou não. O banho. Eles te davam um pedaço de sabão de fazer limpeza ou de lavar roupa, sabão barra. Mandavam fazer uma fila de manhã cedinho e distribuíam os pedaços de sabão. Era uma fila enorme. A hora da higiene era das $6 \mathrm{~h}$ às $7 \mathrm{~h}$ e depois íamos para a fila do café. Então, às $7 \mathrm{~h}$ você já tinha que estar pronta para o café. Voltando para aquela fila enorme no corredor para entrar no banho. Você tomava banho com aquilo e eles pegam uma escovinha dental e colocava um cremezinho sobre ela e aquela filinha. $O$ familiar não podia trazer nada. Enfim, eles vão te inutilizando. A dor da perda ali, é muito grande. E essa tortura do Haldol, que 
eles dão... eles trituram no chá ou na água e faz você tomar. Um, pelo menos, segura o nariz, o outro segura os braços e empurram para dentro. Você tem que tomar. Você diz: "Não. Isso não está bom, eu não quero". E prende os dentes e range para um lado e para o outro, sabe? Aquele movimento que eu conheço hoje, o movimento involuntário das mandíbulas, que eu acabei lendo depois. Então, essa é a reação dessa situação, que me fez ter a perda dos dentes. Mas quando a gente está nessa situação, um paciente tenta ajudar o outro, chamar alguém. E a resposta é sempre a mesma: "Ah, não. É problema de saúde dela. Pode deixar. É assim mesmo". Mas não é! Ele está condicionando você a ficar daquela forma. Então, é muito doído, dói muito. Não só a perda física, mas a perda mental, a perda da informação. Então, antes, eu estava trabalhando, vivendo a minha vida. E, de repente, eu não consigo fazer mais nada e não tenho saída. Aí, se passaram mais de 20 anos nisso. E um dia, eu já não tinha mais a mamãe. Ela já tinha ido a óbito também. Aí, o meu irmão e a minha irmã foram, direto, lá no manicômio. Continuaram me visitando. Os meus familiares: a Tereza, o Luiz, o Francisco, a Aparecida. Enfim, na minha família, nós somos dez filhos. E aí, o que aconteceu é que me visitavam. Eu tinha uma sobrinha, que é do meu irmão, ela falava assim: "Tia Sônia, você não quer que eu fale com eles? Toda vez que eu vejo você, você não está bem. Eu não sei, não está bom”. Mas, gente, eu não tinha essa autonomia, nem de voz, eu não sabia nem falar. Era tudo enrolado, tudo preso. Vivia trêmula, babando, andava me arrastando. Não tinha vida. E o médico reuniu a família e disse: "Não. Não tem mais jeito. Não pode mais ir para casa". Ele chegou para mim e disse: "Você é crônica. Você não pode mais ir para casa". Eu falei: "Doutor, isso é resultado do tratamento que o senhor está me oferecendo".

Hoje, o CAPS, ele traz uma nova alternativa. Então, depois que a minha irmã me tirou. Lá em 2009, eu fui para casa e eu não saía nem na porta. Eu tinha medo de tudo. A família tentando trabalhar e viver comigo. Conviver, não era possível. Ou era a cama ou era chão, assim. Eu deitava no chão, que eu estava acostumada com isso lá, encolhida. Não agia para comer e era dependente de tudo. Aí, depois de quase mais seis meses ali, naquela situação, uma médica da Secretaria de Saúde do São Bernardo do Campo veio à minha casa e me disse: "Hoje é o seu aniversário, Sônia. Eu sou médica, eu vim da Secretaria de Saúde, vim te visitar". E começou a conversar comigo. Eu respondi: "Médica? Não. Isso é um anjo. Médica? O quê que está acontecendo? Médica aqui em casa...” Aí, ela começou a conversar comigo. Chamou o meu irmão e conversou. A minha irmã, conversaram: "Olha, a gente gostaria de oferecer um tratamento [no CAPS]". O que eles fizeram em uma ... foi ver o que aconteceu com alguns outros pacientes que não saíram, porque a [Edilaine estava aí], foi batalhar lá dentro do Lacan, né Dila? Buscar o pessoal que, hoje, a gente... Depois, a gente... Disso eu ainda não sabia. Aí, eu aceitei ir para esse 
CAPS. Então, a negociação demorou mais de um mês. E, hoje nós estamos ali no CAPS, Centro de Atenção Psicossocial. Então, quando eu cheguei lá, foi aí que eu encontrei todo esse pessoal que estava lá no hospital. Porque quando eu saí, eu falei: "Olha, eu tenho certeza que hoje nós vamos sair todo mundo". Aí eles falaram: "Não. Não sai mais não". Aí eu falei: "Sai sim". Eles disseram: "Eu não tenho família". Eu falei: "Mas Deus é bom". E aí o que aconteceu é que é a surpresa. Quando eu cheguei no CAPS, eu encontrei todo mundo na sala de convivência ali e fui trabalhar no hospital. Então, estava tudo no começo, estava novinho. Ainda tinha algumas pessoas.

Como disse o pessoal, estava fazendo essa remoção, vindo para as residências terapêuticas. Depois, eu fui conhecendo. E eu sentava naquela salinha de convivência, acabou que assim foi indo olhando para todo o lado, o meu irmão ia me levar. Depois, disse que ia me buscar. “Será que ele vem mesmo? O quê que vai acontecer?”. E também eu não saía, medo, medo de tudo. E está na hora do seu remedinho, eu tomava, tem um almoço, tem isso. Mas dali eu voltava e ficava, não fazia nada. Aí eu falei: "Está. Aqui eu estou melhor". Aí eu fui me refazendo. Aí o meu irmão vinha mesmo me buscar, chegava lá: "Sônia, está na hora de você ir". E pegava na minha mão: "Vamos embora". Eu falei: "Vamos". E no outro dia... Então, todo dia da semana eu estava... Ainda hoje, gente, há quase sete anos, eu fui todos os dias no CAPS. Eu sou paciente HD. E graças a Deus e graças a todos vocês, que são valiosos, os profissionais que lutam junto com essa militância maravilhosa. Hoje eu sou uma militante também. Então, a gente foi melhorando, ali tinha reuniões, depois vinha a psicóloga, a psicóloga apareceu, depois que eu não precisava mais.

Aí foi isso, gente. Eu fui sendo tratada. O tempo foi passando e aí eu conheci ... Eu passei assim pela cozinha, tinha um... Pelo CAPS, o pessoal fazia assim uma... algo, docinhos, alguma coisa de culinária. Aí eu me interessei por aquilo, mas eu estava indo para a reunião da ajuda mútua...um grupo, algo de ajuda mútua. Então, eu me lembro da Elizabeth, a doutora Rosana, o senhor Osvaldo, tinha o doutor Dráuzio, mas não é o da televisão não, viu gente? Várias pessoas, o Leandro que ainda está e é advogado. Então, fazia essas grandes reuniões e eu comecei a participar, mas eu não estava entendendo nada. Aí eu escutava todo mundo falando, a gente começava a falar, nós não estávamos nem entendendo o que nós mesmos estávamos falando, fazendo. Eu sei que daí surgiu o seguinte fruto, eu passei a participar dessa culinária e desse grupo. Então, a proposta da culinária, desse grupo, que era uma geração de renda, você vai poder ganhar. O quê que a gente [pensa]? De fazer uns pratinhos na tarde, duas vezes, pelo menos, na semana, para vender para os próprios funcionários. Então, eu ia para o alimento e o outro ia receber. 
Aí a gente foi e isso... Aí encontrei que o nome dela a Maria, que dentro do hospital era Joana D'Arc. Então, até o nome dela estava trocado, por isso que não ia sair. Ele falou: "O meu nome não é esse". E aí foi isso, gente. E hoje a gente... Nós estamos tudo junto. E desse grupão... Aí eu participei, ainda fiz uma culinária, fui saindo fazer um curso de culinária e não sei o quê, de... eu sou confeiteira. E aí, depois, a gente começou a vender o pastel lá fora, tal. E aí fiquei mais um ano e aí o grupão foi avaliando, a gente foi querendo montar, então, uma associação. "Aí nós precisamos de associação. Porque todo mundo tem o mesmo sofrimento, vamos fazer". E assim foi e a gente recebeu também a visita do professor Eduardo Mourão e todos esses profissionais juntos nos ajudaram e, hoje, então, nós estamos dentro da Associação Mente Ativa. Então, até o nome nós escolhemos, que a gente ia falar lá, opinava sobre os objetivos e o que a gente precisava, tudo. E lentamente aí chegou o dia. Olha, a gente vai... Então, agora, vamos ter presidente, vice-presidente, primeiro e segundo secretário e uma diretoria a ser formalizada. Aí eu logo levantei a minha mão: "Eu quero ser a presidente".

[Risos].

E, hoje, nós estamos com quatro anos de Associação Mente Ativa junto com o tratamento. Eu ainda vou lá fazer o meu artesanato, eu vou lá na minha consulta com a psicóloga, vou na minha consulta com o médico, vou lá no [hospital Mário Covas] buscar o meu remédio. Eu conheci o doutor Tadeu lá do Ministério da Saúde. O ano passado fui lá na OPAS do Chile e foi muito bom. E aí a finalização desses quatro anos, a gente está formando uma nova diretoria que são mais oito componentes. Então, o André agora provavelmente será o presidente. Então, eu não posso mais do que isso. Aí eu falei: “Gente”. Eu estou fazendo faculdade agora (risos). [Palmas]. Então, eu vou ficar como consultora agora da associação. É isso. E é um prazer estar aqui com vocês. A Prof.a Sônia Barros, todo mundo aqui que eu conheço. Eu conheci hoje, a gente se conheceu. Então, várias pessoas aqui. Então, é um prazer imenso. Na faculdade teve inclusão social no trabalho e eu fui peça do trabalho, além de ser integrante do grupo, eu estou no segundo semestre. Eu ganhei um computador. [Risos]. Um notebook. Porque o ano passado, antes de fazer o vestibular, eu fui fazer informática. E aí foi, a gente... Gente, a gente tinha uma roda de conversa no CAPS. Agora, a gente tem seis e a gente é militante. Essa PEC 55, a gente vai pegar ela pelas manifestações. Está bom, gente? [Palmas]. Eu gostaria de falar sobre a inclusão social da família, essa aqui é bem difícil. Porque quebra mesmo os vínculos. Embora a minha família me visitasse, a gente estava distante já, não tinha mais vínculo. Como eu disse, a minha sobrinha olhava mim: "Tia Sônia, eu posso falar com o médico". Ela estava com nove anos. Hoje, ela 
já está casada, ela é formada, nós estamos no... Ela fez também administração. Então, a Luana, ela olhava aí o papai dela: "Mas o quê que é, Luana? O médico falou que ela precisa ficar mais um pouco". Então, é o que o médico passa para a família. Então, até os olhos de uma criança dá para ver que isso não está certo, né gente? Então, quando a gente olha para isso, a gente vê que a inclusão da família é difícil. E quem perdeu mais ainda com isso e não está com um vínculo familiar, a gente faz essa roda de conversa e traz para a realidade. A residência terapêutica, ela traz esse vínculo, um vínculo em família, vem seis, sete pessoas, cinco pessoas em uma casa. Passa pela associação, vai no módulo do CAPS, a gente ali é uma grande família. Então, nós estamos... nós aqui somos, hoje, uma grande família. Por isso são laços que a gente vai atrelando e vai construindo, essa é a verdadeira luta do dia a dia. A luta seria essa unidade. Estarmos juntos sempre. Porque aí é que a gente pegar todos esses que estão contra e já haviam perguntado: “Mas será que no meio desses profissionais não tem algum que...”. Não é que não tem, tem muito. Então, fora é valente. E nós tivemos em 30 pessoas lá.

[Palmas].

Outra coisa que eu gostaria de falar é a respeito... Por que eu procurei uma psicóloga, um psicólogo? Eu achei que eu precisava falar. Como que ele morre em 15 dias dentro de um hospital. "Olha, daqui a 15 dias você vem fazer a visita para a mamãe, para eu ir no hospital". O médico fez a mesma trajetória: "Olha, leva para o médico do hospital para ele avaliar". Chega lá: "Olha, o senhor vai ficar. Olha, ele vai ficar. "Não. Porque ele vai ficar à vontade e tudo. Nós vamos... Daqui a 15 dias, vocês podem visitar. É protocolo, é um modo de atendimento". Poxa, quando nós estávamos saindo de casa, parece que eram cartas marcadas. Quando a gente estava saindo para ir: "Ô, volta aqui, olha. Tem um telefonema do hospital, o papai foi a óbito". Gente, que choque, que dor. Você não sabe, agora eu consigo falar, mas antes eu não conseguia, isso ficou... E depois ele veio em um caixão, todo sem cabelo, todo marcado. Então, o que foi aquilo? Uma tortura. Ou levou choque, sei lá o quê mais, o que mais que houve. E o meu cabelo não era diferente, era cortadinho bem curtinho, viu? Porque lá era o piolho, é isso, é aquilo.

Enfim, é todo mundo naquele sofrimento grande mesmo. Então, quando a gente olha a inclusão social da família, o psicólogo, que tem o... tem um profissional, mas ele não fala com a gente. Então, nós precisamos falar. O quê que é a roda de conversa hoje? $\mathrm{O}$ quê que o paciente faz? Aí eles olham para mim: "Você é profissional da saúde". "Não. Eu não sou, eu sou uma paciente que tenho entendimento". A gente tem dia, hora marcada, a gente tem um contrato realizado em cartório e nós temos uma sala de trabalho, sabe? Então, está aí, gente, a evolução. A gente senta: “Olha, esse espaço é nosso, dos profissio- 
nais, é de todos nós, é da nossa família, é de todos nós. Vamos conversar?”. A gente tem roda de conversa. Gente, hoje, eu caminhei em cinco CAPS, nós estamos em seis. Seu Miguel, agora, é o secretário da associação, ele continua na associação, porque ele entrou em 2014. Então, a gente tem uma cartilha de orientação básica oferecida pelo professor Correa que, hoje, está trabalhando na UFRJ, do Rio de Janeiro. Ele é um professor de saúde mental, é terapeuta ocupacional. Então, ele levava os estagiários, se encantou com o trabalho e ficou e ele preparou todo um trabalho. Uma florzinha aqui, um trevinho, como que nós conseguimos isso daí virou o logotipo da associação? Em uma semana que era... que em outro... naquela semana seguinte que seria o dia das mães, então, a gente tem uma caixinha de ferramenta, nós fizemos uma caixa de ferramenta onde nós colocamos os temas que queríamos discutir. Então, um menino, então, até albergado que estava ali, ele tirou o tema família. E foi tão lindo, que nós falamos: "Na próxima semana é dia das mães. Gente, vamos fazer convitinhos para convidar as mães. E a gente vai fazer só o convite? Não. Vamos pôr um desenho ou um presente para essa família." E aí, o que aconteceu é que... "Ah, vamos fazer uma florzinha, tudo igual". Aí começamos a fazer trevinho, trevinho e fomos e fomos. Aí depois a gente descobriu que isso era um trevo, a gente fez lá tudo verdinho, a florzinha e 186 convites nós produzimos de cartolina. Depois, o presente em 2014 foi o logotipo da associação. E essa cartilha, o professor olhou dentro o que acontecia e ali ele retratou a reforma psiquiátrica, a cidadania que tem que percorrer o paciente com a lei 10.216. O protagonismo, a roda de conversa que é essa, que a gentechama interagir.

É isso. O território em um cenário do cuidado. Então, tudo o que está acontecendo também depois, depois disso a gente evoluiu mais cinco CAPS. Então, nós éramos uma, agora, nós somos cinco, seis. E a gente, agora no próximo ano, nós já vamos querer pedir um novo. E nessa posse desse prefeito já falamos: "Nós estamos aqui". Final do mês queremos fazer uma audiência pública aqui nesse município. Nós queremos que eles nos conheçam e queremos conhecer o projeto que ele tem para a saúde mental. Qual o plano de governo dele. Entendeu? Não ir lá e falar: "Não. Então, eu tenho atendimento aqui com a minha psicóloga, uma vez por semana, eu a encontro. E aí a Taís conversa comigo maravilhosamente bem e é isso, a gente vai reconstruindo junto. E é com todo mundo assim, todo paciente tem o cuidado, tem a atenção e tem tudo. E no final do ano agora, a gente vai fazer a festa de natal. E a associação já ofereceu os ofícios, como sempre, para arrecadar também. É prazeroso a gente trabalhar junto. E a comunicação é uma coisa que vai muito acontecendo e também é a fé em Deus, que traz para a gente os anjos do céu. Então, vocês são anjos vindo do céu. Muito obrigada! 


\section{Mesa redonda - Avanços e desafios da lei $n^{\circ}$. 10.216/2001}

Coordenação: Prof. a Dr. a Sônia Barros Enfermeira, Professora Titular do Departamento de Enfermagem Materno-Infantil e Psiquiátrica da Escola de Enfermagem da USP

\section{Sr. Paulo Gabriel Godinho Delgado}

Sociólogo, Deputado federal no período de 2006 a 2011. Presidente do Grupo Brasileiro do Parlamento Latino-Americano. Autor das seguintes leis: de Cooperativas Sociais, da Reforma Psiquiátrica e Lei Orgânica dos Partidos Políticos

Eu agradeço o convite que me traz aqui. Eu queria agradecer muito a você Sônia, e a sua equipe, todos os organizadores, ao doutor Sérgio que é procurador no Rio de Janeiro, e ao Pedro que é meu irmão há mais de sessenta anos. Permitam-me iniciar lembrando uma dúvida clássica sobre o sentido da vida. $\mathrm{O}$ mundo é digno de riso ou de lágrima. O Padre Antônio Vieira, interpretando Lenda Grega, que envolvia dois filósofos, assim decidiu. Demócrito ria porque todas as coisas humanas lhe pareciam ignorâncias. Heráclito chorava porque todas lhe pareciam misérias. Logo, maior razão tinha Heráclito de chorar e Demócrito de rir. Porque neste mundo há muitas misérias que não são ignorâncias, mas não há ignorância que não seja miséria. Não chame o seu irmão de tolo. Não diga a ninguém "seu louco". A rigorosa excreção pejorativa é um insulto desde os tempos bíblicos e exige justiça para que seja reparada. Uma forma que a humanidade democrática encontrou de encarar de frente a verdade das coisas foi representar a sua posição no plano jurídico e constitucional. O direito de todos a um tratamento informado e justo. É o que o Brasil fez na sua lei nesse longo debate que leva a essa conferência de avaliação e reavaliação, críticas e sugestões como sugere com lucidez permanente o nosso querido Domingos. Quinze anos de uma lei fundadora.

Não. São mais de cem anos na luta de fundadores de uma nova maneira de ver a medicina. No Brasil a fundadora da lei é a persistência do Movimento Nacional da Luta Antimanicomial e os fundamentos que o impulsionam. Humanismo, ciência, técnica, comunidade, afeto e história. Era preciso continuar o trabalho de todos aqueles profissionais e leigos, que alertas e sensíveis, buscavam reorientar a medicina moderna na 
direção que aponta para a unidade corpo espírito e querer assim encontrar a origem da fabricação das doenças orgânicas, físicas e mentais. Não sou médico, psiquiatra, assistente social, auxiliar de enfermagem ou gestor. Sou candidato a paciente e, enlouquecido, quero ser tratado num serviço aberto, o melhor dos CAPS que vocês tenham. Da Lei 10.216 de 2001 eu posso dizer o seguinte nessa hora. A partir do que ouço, leio, vejo, escrevo, acompanho e defendo todos esses anos em solidariedade aos que sofrem, trabalham e lutam, pela abolição completa da solidão e do isolamento do doente mental brasileiro. Cuidado com substantivo, adjetivo, com interjeição. Cuidado é o zelo dos preocupado. Cuidado e esmero, é precaução. Cuidado é advertência para o perigo, é vigilância, dedicação. Cuidado é encargo, é lida, é proteção, atenção, tomar conta. Cuidado é acolher alguém. Cuidado é o princípio que norteia essa lei. Evoluir à clínica, fazer do intratável o tratável. É essencial o apoio social e familiar que influencie comportamentos, mude hábitos, confronte preconceitos, classificações, nosologia, catálogos de interdições dedicados a cidadãos enfermos cuja doença os fez desacreditados, vistos como sem vontade, liberdade ou autonomia porque foram colhidos pelo mal de viver. Não é a doença mental que a lei questiona, mas a maneira de tratá-la.

A sociedade cria e recria normas para definir o que rejeita e o que consagra. Faz-se progressista na área da saúde mais por atitude de bons profissionais do que uratos de rotina médica. Assim inscrever o doente mental na história da saúde pública é aumentar a sua aceitação social, diminuir o estigma da periculosidade e da incapacidade civil absoluta de contribuir para elevar o padrão de civilidade da vida cotidiana. Já é hora do parlamento brasileiro se movimentar outra vez e avançar na elaboração de leis correlatas essenciais e inadiáveis sobre a inimputabilidade e as medidas de segurança para o louco infrator. Não fizemos isso na época porque não havia possibilidade de distrair a nossa luta com tantas informações ao povo brasileiro. E aí, por uma decisão do Movimento Nacional da Luta Antimanicomial e todos os apoiadores dessa lei, nós adiamos a discussão da lei do louco infrator. E hoje com um congresso tão infrator está muito difícil pedir a eles que cuidem dos doentes mentais. A doença mental não é contagiosa. Ela dispensa isolamento. Não pode ser compreendida como estritamente orgânica, apaziguada só pela quimioterapia e os remédios. Não há necessidade da Psiquiatria Biomédica se agarrar a farmacologia para se fazer científica. Mas é claro que o avanço da Medicina e dos medicamentos, é claro que foi esse avanço que permitiu a reinserção social, a convivência, restituindo ao indivíduo a sua alma e o desejo ao mundo dos vivos. O que não significa esquecer. E os senhores e senhoras profissionais da área sabem. Muitas vezes água com açúcar dada com amor faz mais efeito do que remédio dado com indiferença. 
A Medicina não deve ser carceral para não ampliar a solidão moral do paciente, como se a sua doença criasse para ele um mundo do não direito. Para o humanismo sanitário a técnica só pode ser um instrumento da medicina, se usada com respeito e bondade. Porque me arrisco a dizer isso aos senhores e senhoras, profissionais da área médica, a expectativa de cura ou melhora que pertence ao corpo é bem menor do que a esperança que pertence à alma. Ninguém se cura se não quiser curar. Ninguém se salva se não quiser salvar. E é esse restinho de razão que achou nas pessoas para construir o primeiro acolhimento tão incompreendido às vezes pelo estudo da história das doenças mentais, é esse restinho de razão, esse humanismo que está em todas as pessoas, esse grãozinho de areia que todos temos de humanidade, é esse que nós devemos sempre procurar, mais que um remédio, a esperança, o desejo, o acolhimento, a mão estendida, a certeza que eu quero você aqui do meu lado com saúde. É isso que às vezes faz muitas pessoas desacreditadas ou abandonadas em hospitais ou em casas, solitárias, filhos que abandonam pais, pais que abandonam filhos. Por que muitos sobrevivem? Por causa disso. A mão estendida que uma parte da sociedade estende a outra e que o ideal seria que todos nós pudéssemos ter essa máxima que o Domingos terminou o discurso dele. Você não precisa de acreditar de mim, mas confie que eu estou sendo sincero e que estou indo ao máximo do que eu posso e vou procurar chegar até você, encontrar o caminho que possa não lhe curar, mas fazer você conviver com o que você tem e ser respeitado. Acolhimento, tratamento precoce, melhora a evolução e a direção da doença. Agir antes do surto para não ferir, ferir-se, para não quebrar. Sintomas físicos, queixas, mal-estar, sempre foram indícios de várias enfermidades. Melhorar a escuta geral dos sintomas aparentemente sem importância. As dores de cabeça que não passam, os tremores, as dores abdominais, o cansaço extremo das pessoas adoecidas, adoentadas, a falta de ar agravada pelo embrulho e o ruído da adolescência, o álcool, a droga, o conflito de gerações, as esquisitices, o vazio existencial, a impaciência com o indiferente, com antipatia. Os senhores e senhoras sabem, não se entende outra pessoa. Dá muito trabalho gostar do doente mental. Dá muito trabalho trabalhar na área médica. Por isso nós devemos estar sempre abertos para os novos paradigmas que se impõem diante da urgência, que é compreender o fracasso das estruturas simbólicas dos jovensno mundo do crack.

Qual é o código cultural no qual se assenta a regulação da existência de tantas pessoas em tão pouco tempo no nosso país? Por que a universidade não se dedica a estudar, pesquisar? Por que essa velocidade, essa idiota dessa droga entrou nesse país e está dilacerando a juventude brasileira? Droga que não leva ninguém a São Francisco em busca de alguém com fita no cabelo. Uma droga que não produzirá música de esperança. Uma droga que não produzirá alto estoque, uma droga que não produzirá resolução, 
não produzirá mudança. Não é uma droga de um mundo em movimento. É uma droga de um mundo atrasado. É uma droga do passado entrando no futuro, sem ligar para o presente. Porque o Brasil não liga para o seu presente. O Brasil não se importa com o seu presente. É por isso que ele nunca deixa o passado passar. E é por isso que ele nunca vislumbra um futuro para a sua sociedade. Como assessor, como assessorar, como ser assessor? Como defender a garantia de direitos? Como não entender que essa droga quebra a mãe pobre e não se regula mais pela economia dos signos, mas pela mais pura economia de mercado? É o máximo que liberalismo chegou é o comércio do crack. Ele não tem nenhuma restrição. Ele não tem nenhum limite, além de ser uma droga suja. Ela é a droga da droga e está por aí em qualquer lugar. Embora um bom caminho seja sempre o de procurar ver a realidade, da posição que nos encontramos agora, é fundamental não esquecer em relação aos adolescentes que a sociedade considera problemáticos, que uma criança maltratada cresce como uma fruta cheia de bicho. Amadurece cedo, muitas vezes apodrece porque incorpora o que aprendeu de quem a agrediu ou a ele mentiu. Mas se você olhar para o presente desse menino apodrecido como fruta e o amar, e o acolher, e o atender, e o respeitar, você certamente poderá estar ajudando a esse garoto a ser um pai adulto e respeitoso no futuro. Isso já foi dito de várias maneiras diferentes. Mas nós precisamos de encarar.

A luta antimanicomial precisa de encarar a questão da droga na juventude, a questão do álcool na juventude. Por que não se consegue proibir a publicidade do álcool nesse país? Todas as pessoas podem beber. Isso aqui não é uma palestra pentecostal. Mas por que as pessoas são ensinadas a beber? Por que não consegue se deter uma propaganda de cerveja? Por que não é um ato exclusivamente de beber um copo de uma cerveja? Por que você acha que vai ser levado para a Europa bebendo uma cerveja? Ou que vai montar num cavalo que você não conhece a raça ou de que vai ver uma pessoa que não está na sua mente? Qual é o mistério? Por que não se consegue deter? O mundo já acabou com a propaganda de cigarro. Então porque não acaba com a propaganda de bebida? Como se a bebida se pudesse ensinar. As pessoas podem fumar, mas você não deve ensiná-las a fumar. As pessoas podem beber, mas você não deve ensinavas a beber. Não pode ter publicidade daquilo que é 100\% livre arbítrio. É uma decisão pessoal de qualquer pessoa independente.

Enfim, não adianta, pois, querer medicalizar problemas sociais e manipular a política pública para enfrentamento tão complexo? O Ministério da Saúde com esses alertas que o Domingos faz tão bem, deve resistir aos que querem se apropriar do Plano Nacional de Combate ao Crack para ressuscitar o manicômio. Uma luta que o Pedro foi 
coordenador de saúde mental, sempre fez. O Programa de Álcool e Drogas, o Programa de Combate ao Crack, tem que migrar do Ministério da Justiça para o Ministério da Saúde e quiçá para o Ministério da Educação ou talvez para o Ministério da Cultura, se ele ainda sobreviver algum tempo. Ou seja, nós temos que enfrentar a tradição brasileira de tutela sob as pessoas doentes. As razões de tutela à tese, me parece, de doutorado do Pedro. Bom livro. Então. Está esgotado. Foi dali que eu tirei essa coisa. A tradição brasileira agravada pela sedação e o isolamento, isso aí já é meu, não precisa... está culturalmente arraigada e é especialmente grave na área de saúde mental, toxicomania e alcoolismo. Mas a internação e o isolamento só encontram aceitação social se a sociedade não encontra os serviços descentralizados, comunitários, abertos com a mesma facilidade que encontra o mal que a desampara. Todas as vezes que eu vejo crítica à reforma psiquiátrica, hoje andando por todos os lugares que eu ando hoje numa outra atividade profissional, sempre digo. E sou abordado.

No início me chamavam de deputado dos loucos. Hoje me chamam de um deputado louco. Mas eu ficava ali, conversava. As pessoas diziam: - vamos mandar para a sua casa a minha tia. Você vai ver. Fica lá com o meu menino. E grandes intelectuais confrontaram a lei, resolveram da forma que consideraram relevante para eles e para a sua formação, resolver o cuidado dos seus filhos. Mas não tem sentido de usarem o seu prestígio para imaginar que o que encontraram de conforto para o seu filho, deve ser estendido aos filhos de todos os brasileiros. E esse confronto foi feito, porque uma vez me perguntou para que era a reforma, para quem era a lei. Eu disse: - não é para o senhor. É para o seu filho. Ou seja, é muito difícil você confrontar uma pessoa, uma família, que é o que o Domingos disse, confrontar alguém, estar mergulhado naquela questão, estar sufocado, estar sofrido, e sofre porque tem alguém na família com esse problema. Mas o que eu tenho percebido, quando ando e me perguntam, é que onde tem um bom CAPS não tem reclamação. Onde falta o serviço substitutivo tem reclamação. Então não é contra a lei que se reclama. Se reclama do fato da lei não estar sendo aplicada. É a aplicação da lei que as pessoas que reclamam, querem. E não a sua revogação. Ou seja, é inaceitável, assim, usar o terror e o pânico para buscar legitimidade para a internação prolongada própria da obsoleta cultura manicomial. É igualmente inaceitável regredir a doutrina moral de base religiosa que distancia da realidade do sujeito à família e do seu contexto, renegando a subjetividade e a vida prática.

A descentralização que está prevista, e é um dos princípios do SUS, ou seja, ter os serviços cada vez mais perto das pessoas. A universalização, qualquer um que me procure provavelmente está precisando de mim. O serviço tem que ter a porta aberta, tem que 
ser universal, tem que ser descentralizado para que não haja essa circulação de pessoas de uma comunidade a outra, de uma cidade a outra. As ambulâncias psiquiátricas enlouquecem o nosso doente mental. Todos acham que ele é louco. Às vezes é o motorista da ambulância que é louco. Ele foi treinado para treinar um paciente em surto. Ele surta o paciente. Eles dirigem rápido, com sirene. Imagina. Você já está em surto, o cara mete uma sirene, sai por aí, tem quebra- molas, então não dá, Enfim, A instituição nova que nós queremos e que criamos com essa lei da reforma psiquiátrica não tem retorno e tem o nome do acolhimento, o tratamento em liberdade. Aí está a cidadela principal dessa lei, a solidariedade e a cidadania, ver a dor dos outros como se fosse a nossa própria dor. Sustentado por ações múltiplas e intersetoriais, mais adequadas a cultura mais rica e complexa da medicina da mente e das doenças de longo percurso. Não é uma doença fácil. É uma doença longa. E é preciso tratá-la e abordar a doença de maneira diferente de outras doenças.

Saúde não é ausência de doenças. É um estado geral de bem-estar físico, psíquico e social como bem define a Organização Mundial de Saúde e a divisão de Saúde Mental tão bem dirigida pelo nosso Benedetto Saraceno, que me fez o maior elogio que essa lei já recebeu no mundo, Paulo, vem de você e da sua gestão. Ele disse que é a mais harmoniosa lei de saúde mental que tem no mundo porque ela tem a capacidade de falar com a sociedade, falar com os usuários, falar com o Ministério da Saúde, falar com os técnicos e falar com os pacientes. Todos estão envolvidos. E onde não estão todos a lei nãofunciona.

A doença não é um fracasso. É um evento na vida da pessoa que não cria para ela um estatuto de exilado em relação ao que é ou está normal. Se compareço a um serviço de saúde e não tenho amparo para a minha dor doente é o serviço. A doença é um processo que exige observação tolerante, advertência, preservação de direitos. Imaginem se a maternidade fosse igual a um hospital psiquiátrico. Não tinha neném no mundo. A mulher travava e não nascia. Verdade. Não é verdade? Mas num lugar que você chega, já vem uma roupa assim, tem flor para todo lado, as enfermeiras parecem que elas estão grávidas. Não é? Sentem a dor da mãe como se fosse o próprio parto. Quem não quer ir para a maternidade? Tem mulher que não está grávida e vai para a maternidade. Porque é um hospital jardim. Por que não é assim os nossos CAPS? Por que não são assim a atenção aos doentes mentais, como eram antigamente? Mesmo o tratamento da tuberculose, da pneumonia, as grandes doenças pulmonares do início do século, de final do século passado antes de aparecerem os antibióticos e outras coisas, os tratamentos eram mais... não eram tão manicomiais como é o tratamento do doente mental. Ou seja, a doença 
é um processo que exige observação tolerante, advertência, preservação de direitos. A internação é uma parte do tratamento, mas não o seu sinônimo. E o conceito de leito, nesse caso, não se harmoniza com a terapia adequada.

A medicina da mente e suas galáxias têm que se abrir a uma certa imprecisão e passar a duvidar que a cada comportamento corresponda um medicamento. E aí, o Movimento da Luta Antimanicomial tem que enfrentar a legislação americana sobre remédios. DSM5. Essa lei é o diabo. Quem lê essa lei adoece. Porque tem lá, se você não adoece, tem lá um negócio que diz: - quem não adoece está doente. Isso tem que se tirar de vigor. Temos que ligar para o Guterres que agora é o nosso Secretário Geral da ONU. É um português que eu conheço muito, que eu fui observador da ONU em áreas de conflito com ele, quando era presidente de Portugal. E hoje é o Secretário Geral da ONU. O Movimento da Luta Antimanicomial podia procurá-lo para acabar com esse negócio de DSM5 pelo mundo. Deixar os países classificarem, não poder ter uma regra única imposta a todas as sociedades. Ou seja, há muita depressão e sociopatia na sociedade que é impaciente com os seus doentes, tanto quanto com crianças, mendigos, idosos, pobres e deficientes. A sofisticação do diagnóstico é que relativiza a classificação da doença. Eis o paradoxo atual. É preciso modéstia diante do sofrimento. Não é porque não sabe, mas é por que sabe que a psiquiatria, a psicanálise, a psicologia e psicoterapia modernas, baseadas em valores humanos fundam a reforma psiquiátrica.

A dificuldade de diagnosticar é pela complexidade da doença. E o psiquiatra que não é um psiquiatra biológico puro, farmacológico, a psiquiatria humanista que vem lá do nosso querido Basaglia e tantos outros, a dúvida do diagnóstico não é porque não sabem. É porque sabem que tem que ter a dúvida. Ou seja, é preciso então que a internação como privação da liberdade, a monoterapia, só prevalece em serviços despreparados. Tudo isso, porém está incompleto se daí não brotar uma nova economia solidária capaz de incorporar, no ritmo e na sabedoria própria da saudável competição pela vida, o talento e o esforço dos egressos dos serviços e, assim, contribuir para aumentar a vantagem dos que estão em desvantagem. Essa foi a razão pela qual, como corolário da Lei 10.216, apresentei ao Congresso Nacional a Lei das Cooperativas Sociais, sancionada em 1999, antes da sanção da Lei 10.216. Como forma de reinserir pelo trabalho. E assim também pouco tempo depois, em 2003, quando já estava em vigor a 10.216, apresentei, e hoje é lei, o Benefício da Prestação Continuada, que deu base ao Programa de Volta para Casa, criando instituições e serviços novos, fazendo a Reforma Psiquiátrica. O doente mental é também beneficiário do ambiente jurídico oriundo da Declaração Universal dos Diretos do Homem e do Cidadão, como qualquer outro paciente. Seu tratamento não é um 
ato cirúrgico. Está abolida a lobotomia. Só a avaliação permanente do tratamento livra a psiquiatria da ideologia. Não há sucesso médico-terapêutico sem afeto, sem cultura, sem a história da doença, sem a escuta do sofrimento, sem subjetividade.

Como bem sabia e praticava Dra. Nise da Silveira, precursora da lei, a quem homenageio nesse momento. Como ainda não sabem, mas precisam ser conquistados para esse novo horizonte do saber e da justiça, muitos membros do Poder Judiciário e do Ministério Público, em muitos casos com desabrida ousadia invadem o saber médico e sanitário, violam a integridade do indivíduo, fazendo tábula rasa de todos os avanços que quebraram preconceitos sustentados pela pior predição da Psiquiatria, que era o encarceramento de pacientes, tradição pela qual não teriam coragem em outras áreas da medicina. Quero ver um promotor de justiça, um juiz, mandar um nenê nascer com cinco meses, com carta ou por ordem: tira o menino. Por que eles não vão na barriga da mãe? Eles não podem obrigar uma pessoa a operar o outro do coração. Ou pode um promotor obrigar alguém a operar alguém do coração? Como pode um promotor obrigar uma pessoa a tomar um remédio que ele ouviu dizer que é bom? Ah. Ele ouviu três médicos, ele ouviu não sei.... Isso é uma barbaridade. A tradição para a qual se usa de invadir áreas da medicina, imaginando proteger direitos, decidem na verdade internar os incômodos. Na prática, vão reconstruindo hospícios contra a lei. Assim provocam mais mal, imaginando fazer o bem. A proteção dos diferentes não está baseada na diferença de proteção. Enfim, para aqueles que ameaçam a evolução do tratamento e buscam legitimidade para suas críticas, atravessando com desrespeito os fundamentos humanistas e técnicos da lei, quem sabe assim os tranquilizo: Se eu soubesse de alguma coisa útil à minha nação que fosse danosa a uma outra pessoa, eu não a proporia, porque sou homem antes de ser nacional ou ainda porque sou necessariamente homem, não sendo nacional senão por acaso. Se soubesse de alguma coisa que me fosse útil e prejudicial à minha família, meu espírito a rejeitaria. Se soubesse de alguma coisa que fosse útil à minha família e que não o fosse à minha pátria, eu buscaria esquecê-la. Se soubesse de alguma coisa que fosse útil à minha pátria e que fosse prejudicial ao meu continente ou que fosse útil ao meu continente e prejudicial ao gênero humano, eu a veria como um crime. Eu não o faria. Isso não é meu não. Isso é do Montesquieu. É bonito. Foi acusado de várias coisas.

A melhor hora para compreender uma época é quando surgem as suas ruínas. Estando mesmo nós próprios e a rede de proteção e de atenção e serviços em condições pessoais, materiais, profissionais, de dar conta da internação ou do acolhimento voluntário, todos estão em condições, todos os serviços, a rede toda, que instituição realmente nova 
estamos criando? Para quem sofre qualquer tipo de violência ou injustiça o padrão de preponderância do fato é sempre mais relevante do que provar sua evidência. Recolher pessoas ou acolher pessoas? Algumas dúvidas permanecem em nosso meio. Onde colocar as pessoas, como alerta bem o Tykanori, que não tem afinidade com a sociedade como está organizada, mas não podem ser moralmente condenadas por isso. Como aumentar a capacidade de suprimir ruídos e arquivar disputas numa sociedade tão egoísta que está colocando o narcisismo no lugar errado. Fora alguns candidatos militares que estão colocando a ereção no lugar errado porque querem vir para cima da sociedade fazer o que os costumes mandam fazer de outra maneira, com delicadeza e amor. Encerro lembrando o que nos deixou Clarice Lispector, em carta à sua irmã. Clarice foi para a Europa, para Genebra, casada com um diplomata. Deixou uma irmã no Recife. A irmã ficou angustiada e escreveu para ela dizendo que estava... a carta pareceu a Clarice uma carta meio suicida. Clarice respondeu: "Querida. Até cortar os próprios defeitos pode ser perigoso. Nunca se sabe qual é o defeito que sustenta o nosso edifício inteiro”.

Quando os processos psíquicos suplantam os processos sociais vividos pelas pessoas, quem pode dizer com certeza que os conceitos de normal e patológico permitem o conhecimento mais íntimo de nós e a estimativa mais exata do que somos ou do que seremos. Como avaliar o peso na vida adulta dos processos inconscientes que marcam a vida das pessoas desde a infância. Todos sabem que a infância é de lascar. Nossa origem, a origem dos nossos desejos, identificações, recalques, fluxos de energia e criatividade. Onde está o esconderijo de nosso caráter, de nossas motivações e do inteiro teor da nossa personalidade. E aí Clarice diz a irmã:”... respeite o nó vital que há em você. Ninguém tem tanta força assim a ponto de levar qualquer espécie de vida e continuar a mesma. Somente até certo ponto se pode desistir de si própria e se dar aos outros e às circunstâncias. Siga a sua vida”. Enfim, já não é mais a carta. Talvez seja justo enfatizar em cada um de nós qual é a qualidade dos nossos defeitos e assim não deixar predominar na nossa vida os defeitos das nossas qualidades. O que é preferível? Achar qualidade nos nossos defeitos ou só imaginar que devemos procurar os defeitos das nossas qualidades. Todo mundo tem um lado defeituoso. Mas pode ser um usado de qualidade ou um seminovo como se diz nas lojas de automóveis. Enfim, uma coisa é viver, outra é durar. As duas coisas devem pretender a Medicina. Esta é uma lei da sociedade e seus movimentos por liberdade, atenção, justiça e harmoniosa convivência entre pessoas iguais e ao mesmo tempo diferentes. Que este segundo encontro de vocês, com altivez e sabedoria, reafirme e consolide seus princípios.

Muito obrigado. 


\section{Prof. Dr. Sérgio Souza Verani}

Desembargador aposentado do Tribunal de Justiça do Estado do Rio de Janeiro, Ex-Diretor-Geral da Escola da Magistratura do Estado do Rio de Janeiro - EMERJ, Presidente do Fórum Permanente de Direitos Humanos - Escola da Magistratura do Estado do Rio de Janeiro - EMERJ, Coordenador do Curso de Extensão de Direito Social, do Programa Cidadania e Direitos Humanos - Universidade do Estado do Rio de Janeiro - UERJ, Professor de Prática Forense Penal (Professor Auxiliar) - Faculdade de Direito da Universidade do Estado do Rio de Janeiro - UERJ.

(Cumprimentos iniciais) (...)Retrocesso político e social porque passa o Brasil. O Brasil, a Europa, falou-se no mundo endireitado, o mundo facistilizado e no Brasil a gente está vivendo isso com muita rapidez, com muita rapidez e com muita violência. $\mathrm{E}$ eu acho que nenhum de nós esperava que todo esse processo de retrocesso, de aniquilamento das políticas públicas e sociais viessem com tanta rapidez e ao mesmo tempo com tanta facilidade, e ao mesmo tempo com tantos aliados.

Quando se fala do golpe, o golpe é um golpe contra a classe trabalhadora, esse é que é o sentido e o destino dessa transformação política, esse retrocesso histórico, porque o Brasil tem passado. Eu sempre tive uma inveja, eu sou desembargador do Tribunal de Justiça do Rio, me aposentei o ano passado, e trabalhei como juiz de Direito, sempre em vara criminal, durante 40 anos. Mas sempre tive uma grande inveja do movimento da Luta [antimanicomial]. Sempre me seduziu muito, me seduziu por quê? Primeiro pela grande mobilização social, não só dos médicos, mas especialmente dos trabalhadores da saúde mental, dos enfermeiros, dos técnicos e esse encontro aqui é promovido pelo departamento de enfermagem. Isso tem uma importância muito grande, seus trabalhadores da saúde mental, mobilizados pelo reconhecimento de que o seu trabalho na psiquiatria, dentro da psiquiatria tradicional de que falava Paulo Delgado, só produziu, só tem produzido sofrimento.

Quando Basaglia escreve essa produção do sofrimento e esse reconhecimento de que seu trabalho então vale o quê? Não vale nada, não vale nada no sentido do humano, no sentido da garantia da dignidade, da garantia da autonomia humana de cada pessoa. Daí o movimento da luta antimanicomial da psiquiatria democrática. Curiosamente, o Basália diz isso, a psiquiatria democrática na Itália se inspira no movimento que havia na Itália antes, início da década de 60, final de 50 também, do movimento da magistratura democrática. Vocês imaginam isso, havia na Itália em 50, 60, um movimento denominado 
movimento da Magistratura Democrática e nesse movimento é que se inspirou aí toda a mobilização do movimento da magistratura democrática. Depois a magistratura da Itália sofreu uma transformação ligada ao sentido, do alto positivismo, da exacerbação da comissão, queremos todos na cadeia. E curiosamente, se a gente ver o cárcere, a prisão no manicômio, que surgiu no mesmo momento histórico, segunda metade do século XVIII, transformação da loucura em doença, transformação do cárcere, da prisão em pena, porque não era pena até então, ninguém era punido a ficar preso. Mas aí a medicina pega a loucura, toma conta da loucura e o direito penal pega e toma conta, o crime e dizendo que a pena, a prisão vai ser agora, a prisão se transforma numa pena. E de lá para cá, a gente vê, curiosamente, o movimento da luta antimanicomial, a lei $10.216 \mathrm{fez}$ esse ano 15 anos e que passa por uma situação difícil, mas é muitíssimo mais saudável estar trabalhando na saúde mental dentro, com todas as dificuldades, do que estar trabalhando no sistema penal, cujas dificuldades, são as dificuldades da ideologia da comissão, que é uma ideologia que se espalha, que vai se entranhando na consciência social.

O Brasil hoje tem cerca de 700 mil presos, 700 mil pessoas presas, talvez um pouquinho menos, ou um pouquinho mais, mas é por aí. É o $3^{\circ}$ país em população carcerária. Isso é um escândalo, isso é um escândalo antidemocrático, não é possível que um país tenha 700 mil pessoas presas. No Rio de Janeiro são 50 mil pessoas presas, é uma cidade. E toda a reivindicação dos governantes, principalmente em época de mudança de governadores, todos lutam por mais prisões de segurança máxima, super segurança. Esse é o desejo aí da condição, o que significa?

O desejo da exclusão, é o desejo do massacre contra determinados grupos sociais. Porque a minha ligação, eu me sinto militante do movimento da luta antimanicomial, até em razão do meu trabalho como juiz. Sempre me preocupou muito e me trouxe sempre muito desconforto essa ideia de que o autor de um crime, que seja portador de transtorno mental, tenha que ficar cumprindo uma medida de segurança que é a medida de segurança de internação obrigatória, que é uma maluquice. Só para deixar isso aqui mais claro, o nosso Código Penal ele ainda é fundado em princípios que não são do século passado não, são do século retrasado, lá do final de 1800 e ainda do pensamento lombrosiano, do pensamento da periculosidade, do pensamento do perigo social... Isso ainda predomina, ainda está vigente no sistema penal, aliás, de quase todos os países, não é privilégio do Brasil, uma falha do Brasil, isso é uma ideologia desse positivismo, que vai se alargando com uma intensidade e com uma perversidade e uma crueldade muito grande. Então vocês imaginem isso assim, o Código Penal ainda hoje determina que esse réu, esse autor de um crime seja portador de transtorno mental, caracterizado 
isso ou confirmado isso pela perícia psiquiátrica, ele automaticamente será internado por um prazo mínimo de um ano. Embora a lei 10.216 não mencione ou não trate da questão específica do chamado "louco criminoso", mas teoricamente ela trata sim e quando surge a lei, quando ela entra em vigor há 15 anos, aí a lei me deu uma alegria muito grande, porque no meu trabalho de juiz e depois de desembargador, eu não determinava a internação, porque o código penal também diz que a internação é obrigatória para todos os crimes punidos com uma pena que chama de reclusão, que são os crimes todos mais graves. E só poderá ser aplicada a medida de medida de segurança em regime ambulatorial dos crimes de detenção, que são crimes insignificantes, que são julgados naquilo que se chama juizado especial criminal. Então o furto, o furto pequeno, se for portador de transtorno mental, o autor ele vai, pelo código penal, ele vai ficar internado durante um ano pelo menos e geralmente fica muito mais. Então aquilo, desde que eu entrei na magistratura, me incomodava profundamente e passei a não determinar essa internação e sustentando este código penal, nesta carta, nesta norma, ela era e é absolutamente inconstitucional, ela é ilegítima, ela, principalmente depois da constituição de 88 , essa norma ela violenta a garantia da cidadania, violenta a autonomia da pessoa humana ali. Então ela não tem legitimidade, mas essa não aplicação dessa lei, ela é muito difícil de ser acolhida por grande parte do Judiciário, do Ministério Público, é porque a leitura do Judiciário é uma leitura muito estreita, é uma leitura de um positivismo absolutamente pequeno.

Depois da lei, essa não internação, ou essa não declaração da internação ficou mais fácil, mais fácil porque a lei determina, lá no artigo $4^{\circ}$, que toda internação, qualquer internação, qualquer modalidade de internação, deverá ser justificada através de um laudo circunstanciado e o juiz não pode, ele não tem autorização constitucional para determinar a internação de uma pessoa se não há indicação clínica terapêutica que determine essa intervenção, indica quais são as razões terapêuticas clínicas que vão indicar aquela internação. Então,, isso para mim sempre foi muito claro, mas para grande parte do sistema jurídico, aí englobando o sistema judicial, do Poder Judiciário, do Ministério Público, é muito difícil de entender isso, é porque eles se falam "não, mas a lei penal, o artigo penal, que é o artigo 97 do Código Penal", se vocês tiverem curiosidade, depois vê lá no Código Penal, artigo 97, que diz isso, a internação obrigatória pelo prazo mínimo de um ano, ainda tem um prazo mínimo de um ano, não é pouco tempo não, é um ano lá internação no manicômio judiciário, que desde 84 não chama mais manicômio judiciário, chama casa de custódia e tratamento, que é a mesma coisa, os nomes mudam, mas a estrutura é a mesma, o espaço é o mesmo, o lugar é o mesmo. E aí então, se diz para negar a internação, que esse artigo ainda não foi revogado, ele está em vigência. 
Na verdade, ele não está em vigência, porque ele é violentador de todo o progresso, do pensamento psiquiátrico, democrático, de todos os princípios constitucionais, que garantem igualmente para todos a cidadania, a dignidade, daí absoluta ilegitimidade dessa norma, que é uma norma que ainda está em vigor, mas que não tem sobrevivência legítima, constitucional, e especialmente humana, porque ela é uma violência contra o sentido mais radical dos direitos humanos. Toda a luta antimanicomial, e eu quero também só para esclarecer, eu faço parte de uma associação que se chama Associação Juízes para a Democracia que teve início aqui em São Paulo, a origem dessa associação foi aqui em São Paulo com alguns juízes aqui, fez este ano vinte anos, no Rio também, há em todo o Brasil, há núcleos do JD em todos os estados, mas, somos muito poucos. A grande maioria mantém que... que faz parte aí deste poder judiciário, não tem aí este pensamento fundado na exclusão social, fazendo do seu trabalho, um trabalho de negação dos próprios princípios constitucionais. $\mathrm{O}$ ano passado, em dezembro do ano passado, eu estava falando que eu sempre tive uma inveja muito grande do Movimento Antimanicomial, há um ano, dezembro do ano passado houve um grande ato na assembleia legislativa do Rio, um ato contra a indicação do então coordenador Valencius. Foi um ato assim de uma, de uma emoção...Assembleia Legislativa do Rio de Janeiro é um prédio antigo, muito bonito, ele agora ele é cercado, o quarteirão onde fica a assembleia legislativa no Rio, ele é cercado por grades, as ruas ao lado, o quarteirão, o prédio ocupa o quarteirão, completamente cercado por que há manifestações contra projetos que o governador mandou e o povo é proibido de se manifestar, mas, essa manifestação na assembleia foi um exemplo de mobilização e de capacidade de fazer uma discussão por que não queremos este coordenador desaúde.

Por que ele não faz parte dessa mobilização, ele é contra essa mobilização. Como agora o ministro da saúde é contra o SUS...é contra esta ideia de (...) exatamente não, não será possível o direito universal a saúde, e eu queria também lembrar já que já se falou aqui de manhã, a lembrança, a lembrança não, a presença de Fidel. Que têm uma, uma relevância histórica, uma importância histórica fundamental. Quer dizer, se conseguiu produzir dentro de todas as dificuldades e as impossibilidades, se conseguiu produzir em Cuba uma sociedade em que o direito universal à saúde, onde o direito universal à educação são políticas, são garantias que não serão aniquiladas e aqui a gente pensa em garantia da reforma psiquiátrica, da mais que generosa ideia trazida pela lei dez mil duzentos e dezesseis, que é esta ideia do resgate da subjetividade humana, do resgate da autonomia e em relação ao sistema penal isto aí passa longe, o sistema penal ainda está lá no século retrasado e ainda se defende aí essa segregação incontrolável, não só nas internações que talvez tenham diminuído mas, no Rio de Janeiro ainda há, ainda há 
hospital, o antigo hospital que é o Heitor Carrilho, ele foi desativado, todos ao pacientes se encontram ou quase todos no hospital Henrique Roxo, que fica em Niterói, que é uma cidade próxima do Rio. Há cerca de duzentos se eu não me engano, duzentos pacientes ou quase duzentos ainda cumprindo internação de segurança e com a ideia também da desativação do manicômio judiciário, está ideia tem conseguido alguns avanços. Há uma resolução do próprio Conselho Nacional de Justiça que recomenda que as medidas de segurança sejam executadas de forma ambulatorial, mas, aí tem a questão do código penal, o código penal manda internar. Então há um embate permanente e há também uma dificuldade nesse não procedimento da medida de segurança em internação manicomial, como medida de segurança em relação ao destino desse usuário, desse paciente.

A questão da Rede, existe um certo conflito entre os profissionais do manicômio chamado Manicômio Judiciário, a Casa de Custódia com os trabalhadores da Rede. Então, são conversas que estão praticamente começando ainda sendo feitas, ainda se articulando para tentar organizar e planejar a não internação. Esse conceito penal chamado de periculosidade, que é um conceito Lombrosiano, há um autor, um professor de direito penal, da Argentina, que é um grande pensador do chamado direito penal critico, que é Eugenio Raúl Zaffaroni, ele era ministro, era da Suprema Corte, da corte argentina e saiu há pouco tempo, se aposentou há pouco tempo e ele é responsável por um trabalho em relação ao direito penal maravilhoso e ele define assim, essa norma, que é uma norma chamada periculosidade ou perigosidade social, ele diz, o Zaffaroni, que o conceito de periculosidade é um conduto de uma ideologia racista, colonialista, pseudocientífica e antidemocrática, que pelo seu desenvolvimento produziu o genocídio nacional socialista, o nazismo e têm produzido os genocídios colonialistas do resto do mundo. Nada mais do que isso significa, este conceito, mas do que um conceito que é uma norma legal e esse chamado de periculosidade. Que tem que ser abolido do código penal, como também precisa ser abolido do código penal a medida de segurança, mais esta dificuldade também é muito grande por que o preconceito contra o criminoso é muito grande e contra o criminoso louco é maior ainda. Então ele fica lá, excluído, absolutamente alijado da vida social. Então são possibilidades de mudanças muito difíceis.

Mas há uma mobilização permanente. E agora recente, aliás, semana passada, esteve no Rio, na Escola de Magistratura uma professora italiana que trabalhou com Bazaglia, que tem textos com Bazaglia, e eu vou ler aqui para não errar o nome dela, Maria Gracia d'Aniqueta. Aliás adorei ela, assim maravilhosa... ela também fala das dificuldades da Itália. Também lá as dificuldades são muitas. As dificuldades em relação à abolição dos manicômios e especialmente em relação com os juízes, com o poder judiciário são re- 
lações difíceis. Mas há vários grupos de mobilização no Rio sobre a reforma, estudando e pensando em como fazer aí esta mudança do manicômio, em relação ao criminoso chamado louco, para a residência terapêutica. Ou para a casa dele, para a residência. Não precisa ficar internado. Mas são dificuldades muito grandes.

E eu cheguei atrasado aqui no vídeo do Domingos, como é bom ouvir o Domingos falando. Eu acho que esse vídeo deveria passar assim em todas as escolas, em todas as universidades de medicina, de psicologia, de direito, de serviço social por que é uma fala muito clara. E questões e mais do que isso a capacidade de luta. Só para lembrar um pouco, as dificuldades no direito, por que o direito mantém então essa ideologia da psiquiatria do século retrasado.

Aqui em São Paulo teve um grande professor de medicina legal e é curioso os professores de medicina legal, eu sempre tive uma certa curiosidade nisso... todos os professores, agora eu não sei, mas assim a tradição da medicina legal, desde os primeiros, até recentemente, eram psiquiatras e ao mesmo tempo legistas, médicos legistas, um grande de grupo de psi... desde Heitor Carrilho, desde Nina Rodrigues, Raimundo Nina Rodrigues, que era, que foi o grande mestre da chamada escola do Nina, professor da universidade da Bahia que era um racista, ele tem um livro, o famoso conhecido a raça do homem comum, As Raças Humanas e a Responsabilidade Penal do Brasil. Ele sustentava que os negros eram desequilibrados morais, estavam sempre em estado perigoso, da mesma forma como Ingenieros, José Ingenieros, na argentina também, falava a mesma coisa. E da mesma forma como também um maisnovo que é o Flamínio Favero, professor da UFU, eu estudei medicina legal nos livros do Famínio Favero e a gente tem que ler cada coisa, realmente, enfim, mas têm que lê... eram três volumes do Falmínio, eram três volumes de medicina legal e não eram pequenos não, eram "parrudos" assim... e o Flamínio Favero, ele fala..., ele era apaixonado pela Nina Rodrigues, ele cita no livro dele, essa obra do Nina Rodrigues e Flamínio fala assim: mais atrasado for uma raça, mas propensão se vê para determinados crimes. E isso que eu estou descrevendo da primeira edição da medicina legal da década de trinta, final de trinta, acho que sim, mas isso permanece ainda hoje, esse pensamento sobre a raça inferior, ainda permanece hoje. Não é por acaso que o Brasil tem hoje setecentos mil presos, setecentos mil pessoas cumprindo pena. Uma das razões disso é também essa ideologia racista, fundada nessa ideia aí de periculosidade.

Eu queria então encerrar. Eu fiz assim umas anotações e fiquei muito feliz de ouvir aqui de manhã... eu vim do aeroporto com a Sandra e a gente falando pouco. Mas depois eu via a Sônia. 
Mas só para completar aqui, eu esqueci, em relação ao Nina Rodrigues, o Nina Rodrigues é, ele acreditava tanto nisso da medicina legal, capaz dessa psiquiatria capaz de descobrir as condutas, de descobrir e de justificar as ações pela raça e eu estou falando disso por que ainda hoje isso se aplica às sentenças, sentenças do século vinte e um não são diferentes de sentenças do século dezenove do ponto de vista do racismo, do ponto de vista da prepotência, do ponto de vista da tentativa de aniquilamento humano. Quando houve a Guerra dos Canudos na Bahia, final do século dezenove, que foi um massacre, um dos maiores terrores da história do Brasil e dizimaram todos no final. Houve uma covardia, propuseram a rendição e todos foram mortos.

O corpo de Antônio Conselheiro que era umas das grandes lideranças de Canudos, foi enterrado, mas aí depois ele foi desenterrado e foi cortado a cabeça dele, do Antônio Conselheiro, foi cortada a cabeça dele e levada para a Universidade da Bahia para o Nina Rodrigues fazer o exame no cérebro, para tentar explicar as causas do poder, daquela violenta organização. Se acreditava nisso. Essas violências, essa violência, ela permanece até hoje, não se corta mais a cabeça, mas, há um grande extermínio, seja no manicômio, maior ainda, muito maior nas prisões. Além do extermínio físico. O Rio, São Paulo também, o Rio de Janeiro é.... quando São Paulo colocou Rota, aqui era a grande organização de extermínio. O Rio também imitou São Paulo nisso. O Rio hoje, talvez seja a polícia que mais mata, no mundo. São assim muitos homicídios praticados pela polícia e homicídios, quase todos, são legitimados pelo poder judiciário e pelo ministério público através de uma fraude que se usa, utilizando-se uma norma do código do processo penal chamado auto de resistência e aí é como se a polícia tivesse resistindo a um ataque e sempre os processos são..., aliás não há sequer processos, os inquéritos são arquivados. Então essa violência muito grande, ela vai se transformando um pouco, mas permanece intacta esse modelo dentro do direito, dessa psiquiatria exterminadora, aniquiladora da condição humana. Mas eu lembrei, ouvindo de manhã de um poeta, que ele nem é tão conhecido, tão popular, mas que é muito bom, que é o Lêdo Ivo. Ele morreu a alguns anos e o ano passado que eu fui ler um dos últimos livros dele publicado que se chama Réquiem, que são poemas belíssimos, a editora acho que é Contra Capa, mas tem um poema que eu anotei aqui, é mais ou menos o último verso do poema, aí mais ou menos ele fala assim, o Lêdo Ivo “... quem tem as chaves dos sonhos consegue abrir as portas..." é mais ou menos assim, eu não sei se é exatamente consegue abrir as portas ou é a porta, mas é isso e quem tem a chave dos sonhos consegue abrir a porta, consegue abrir o muro e quem tem as chaves do sonho é quem sonha. Eu acho que nós aqui, todos nós podemos lutar para produzir e encontrar e achar essa chave dos sonhos e abrir os muros e as portas, todas.

Muito obrigado. 


\section{Prof. Dr. Pedro Gabriel G. Delgado}

Médico Psiquiatra, Ex-Coordenador Nacional de Saúde Mental, Álcool e Outras Drogas do Ministério da Saúde, Professor adjunto da Universidade Federal do Rio de Janeiro, Professor colaborador da Universidade Nova de Lisboa

Quero agradecer a todas as pessoas aqui presentes, é uma satisfação muito grande estar aqui nesse encontro. Agradecer aqui a Sônia Barros pelo convite, a sua equipe, e dizer que eu fiquei pensando que eu deveria, fazendo um esforço muito grande, transmitir otimismo. Então pode ser que parte da minha fala soe um pouco da boca para fora, mas eu acho que as coisas andam tão difíceis que é necessário construir, de alguma forma, algumas perspectivas, algumas saídas, alguns caminhos e algumas formas de resistência. Então, como estamos também num momento de citação de poemas, e foi falado do sonho, tem um verso que é do Álvaro de Campos, que é o Fernando Pessoa, que é sempre muito citado e eu acho que não faz mal ele ser sempre muito citado, porque ele é muito interessante, que é do famoso poema "Tabacaria", que é o começo do poema "Tabacaria", que diz assim: "Não sou nada, nunca sereinada.

À parte isso, tenho em mim todos os sonhos do mundo", que é a epígrafe de um romance que eu estou lendo chamado "Máquina de Fazer Espanhóis", de um autor natural de Angola, mas é um escritor português, que se chama Valter Hugo Mãe. É um romance sobre a possibilidade de construir o otimismo em um cenário absolutamente desfavorável. O personagem principal, que cita esse livro que tem como epígrafe "A Tabacaria", só esses versos d'A Tabacaria. É um senhor de oitenta e quatro anos que é encaminhado contra a vontade para um asilo de idosos em Lisboa, nos anos 2009, e busca reconstruir a sua própria história no diálogo com outras pessoas que vivem naquele asilo, ou seja, numa situação de limitação absoluta de possibilidades de vida, porque eles não tinham autorização para sair. E sem recorrer apenas a uma visão do passado com pura rememoração, ele conhece um outro morador desse asilo que teria sido o personagem do poema “Tabacaria”, do Fernando Pessoa, que é o Esteves sem metafísica, que tornou-se uma pessoa, uma celebridade dentro do asilo, e a partir daí eles constroem toda uma possibilidade de saídas, e saídas no sentido até de saídas físicas, de sair fisicamente daquela situação de prisão, revisitando um poema de 1928, através de uma pessoa que teria cerca de cem anos, e que teria sido o Esteves citado no poema de Fernando Pessoa. Não sei se vai trazer nenhum otimismo a vocês (risos), mas como eu anotei esses versos que tem como epígrafe do romance, eu não pude deixar de ler agora. Eu queria dizer que, 
na semana passada, eu participei de uma roda de conversa formada por familiares de pacientes com transtornos mentais graves e pesquisadores do campo da saúdemental.

O tema dessa roda de conversa é: o que se passou com a minha vida nos últimos dez anos. E eu não posso deixar de me lembrar aqui do depoimento da Sônia de Fátima, que nos contou o que que se passou com a vida dela, as transformações que ela fez na vida dela, que saiu de uma situação de institucionalização para uma situação de exercício da autonomia, da vida ativa, e da solidariedade, principalmente da solidariedade. Pois bem, esse relato, dessa roda de conversa ela aponta alguns percursos que tanto familiares como pacientes e como os próprios pesquisadores, eu inclusive, passamos nesses últimos dez anos. Por que dez anos? Porque foi o pretexto, o ponto de encontro, foi um projeto iniciado em 2005 de pacientes, usuários do serviço de saúde mental, que passaram a ser professores de Psicopatologia no curso de Psicologia da Universidade Federal do Rio de Janeiro. Os familiares se incorporaram, a partir de 2011, em uma tarefa de serem docentes de cursos de extensão, de especialização para outros familiares do campo da saúde mental. E os professores, pesquisadores acompanharam, propiciaram, coordenaram essa atividade e também, por isso, sofreram as transformações que se passou nas suas vidas. E as histórias, não são só histórias emocionantes, são histórias paradigmáticas, são histórias exemplares, são mudanças da possibilidade de construção da própria biografia que jamais, ou que dificilmente você na vida diária das pessoas, de sair de uma situação de dependência institucional. As pessoas falavam assim: "eu não sabia nada sobre o que estava acontecendo comigo, e agora eu sei quais são as minhas dificuldades, eu sei o que que eu devo fazer, sei aquilo que eu tento fazer e não funcionou direito, sei o tamanho dos erros e o tamanho dos acertos, sei também relativizar uma coisa e outra, e vou levando essa possibilidade de vida".

Esse exemplo é para dizer que, a reforma psiquiátrica e a lei 10.216, produziram transformações institucionais, produziram transformações normativas legais e produziram transformações da política pública, que são inegáveis. Se antes da lei havia cerca de duzentos serviços territoriais e, depois da lei, tem dois mil e quatrocentos, mais ou menos, serviços do tipo CAPS; se antes da lei havia cerca de setenta mil serviços psiquiátricos convencionais e depois da lei existem vinte e seis mil leitos psiquiátricas convencionais; se havia cinquenta residências terapêuticas e existem seiscentas e tantas residências terapêuticas, há uma eficácia que deve ser atribuída à lei, não só à lei, mas deve ser atribuída à lei, porque a própria criação de leis posteriores, como a do programa 'De Volta para Casa', o Paulo Delgado mencionou isso aqui, só foi possível porque tinha uma lei anterior que sustentava uma nova legislação que foi aprovada em 2003, no início 
do governo Lula, e aprovada pela câmara, pelo senado e sancionada pelo presidente da república da época, o presidente Lula, porque havia legislação anterior.

Então eu acho que com todas as limitações que podemos considerar, porque o tema (do II ESM) é quinze anos da lei, impactos, possibilidades, etc., que essa mudança é puramente na superestrutura jurídica, todas as limitações e fragilidades que isso tenha, de qualquer maneira, é uma alavanca para as transformações positivas, isso não pode ser desconsiderado. Ao mesmo tempo, também é uma legislação que obteve um alto grau de legitimidade social. É uma legislação que, óbvio, passou por problemas de contestação, etc., mas que tem um elevado grau de legitimidade social, entre profissionais, entre usuários, entre familiares, na opinião pública. Porque ela se opõe a essas imagens que a vimos de manhã, vimos à tarde. Se opõe a esse cenário brilhantemente demonstrado ali pelo Domingo Sávio, dos anos noventa. Então acho que é importante, nós estamos aqui num grupo onde predominam pessoas muito jovens, é importante saber que tem uma história que se construiu uma narrativa, que pode agora competir com outras narrativas, nesse momento, de ataque à democracia brasileira, do estado de direito. Provavelmente vão se construir outras narrativas, mas eu acho que há um histórico que é claramente contado, narrado, demonstrado, documentado e que produziu efeitos na sociedade brasileira.

O Sérgio Verani mencionou essa coisa da periculosidade, das medidas de segurança, e eu diria o seguinte, eu concordo integralmente com o Sérgio Verani, o departamento no qual eu sou professor se chama Departamento de Psiquiatria e Medicina Legal. A ligação da psiquiatria com a medicina legal é uma ligação histórica. O perito forense do caso Pierre Rivière, do Foucault, foi o Esquirol, o psiquiatra Esquirol. Então essa ligação é histórica, ela é intrínseca. O Joel Birman costumava dizer que "os juízes acham que colonizam a psiquiatria, mal sabem eles que são colonizados pela psiquiatria”. E essa coisa do Sérgio dizer: "a gente vê cada coisa", é sensacional, porque eu me lembro de um aluno de curso de especialização que era um psiquiatra já com bastante experiência, que ele me propôs, e eu concordei, dele fazer uma monografia, ele era um psiquiatra forense, ele era perito. Uma monografia, onde ele iria pegar as sentenças que na verdade são sentenças de absolvição, mas que determinavam o recolhimento ao manicômio judiciário para cumprir medida de segurança, e identificar a base psiquiátrica desses juízes, para saber quem eram os grandes autores em que esses juízes se baseavam para tomar sua decisão para aprisionar pessoas em nome da sua liberdade. Bem entendido, aprisionar em nome da liberdade, porque aprisionar para dizer, "não, eles não podem ser presos, porque eles não cometeram crime, porque eles são inimputáveis", portanto fiquem presos. 
Todas essas situações paradoxais são da essencial da relação entre direito e psiquiatria e são da essência daquilo que é enfrentado pela reforma psiquiátrica, pelo movimento da luta antimanicomial e pela lei Então, o exemplo que eu trouxe dessa roda de conversa foi para tentar convencer a mim e convencer a vocês de que não só as mudanças institucionais, não só as mudanças na política pública de saúde são incontestáveis e visíveis, mas que mudanças na biografia das pessoas, mudanças na vida das pessoas, já valem a pena o suficiente para dizer que nós experimentamos em nosso país um esforço de solidariedade, de civilização e de aperfeiçoamento da civilização e que, portanto, se atingiu pessoas dessa forma, nós temos razões para otimismo no sentido de que é amplamente defensável a continuidade do projeto da reforma psiquiátrica. É amplamente defensável [aplausos]. Então é preciso, eu estou dizendo isso porque a gente precisa meio que trabalhar um pouco essa nossa experiência, a Sandra falou da coisa da vivência e da experiência e tal, nós temos trabalhando muito com a coisa de valorizar extremamente o relato de experiência.

O relato de experiência é um aprendizado extraordinário, mas o relato de experiência ele tem que ser a experiência ela tem que ser essencialmente escutada. Você aprende com a experiência, não como fala da sua experiência, mas quando você escuta a experiência do outro, porque aí você fala novamente da sua experiência a partir da escuta da experiência do outro e é esse diálogo que produz o conhecimento. Esse conhecimento que não é um conhecimento, digamos do que o Paulo chamou aqui DSM ou do saber cientifico convencional, mas é do mais puro conhecimento do que é formado a reforma psiquiátrica, é dessa sutileza e dessa riqueza absoluta que nós construímos também. No campo do conhecimento. É uma coisa absolutamente extraordinária que nós hoje possamos dizer que os pacientes com transtornos mentais graves estão, claro, não todos, mas em grande parte, envolvidos em tarefas extraordinárias de produção de conhecimento. Que eles são os nossos parceiros na produção de conhecimento no campo de saúde mental. Nós não falamos mais do que é esquizofrenia sem o relato dos esquizofrênicos. O Franco da Rocha, aqui do manicômio do Juqueri, um histórico psiquiatra da história da psiquiatria brasileira, no seu livro mais conhecido ele colocou na apresentação, no início do livro, é uma frase que é muito curiosa, que ele dizia que esse livro ele não foi escrito com os manuais de psiquiatria europeus ele falou assim, "ele foi copiado dos doentes", ele falou assim, que foi copiado dos doentes para ressaltar que era baseado na sua experiência de psiquiatra de quarenta anos, que foi diretor do manicômio de Juqueri nesse período. A diferença é que "copiar dos doentes", coloca os doentes em posição muito passiva na produção do conhecimento e ao copiar dos doentes ele estava ilusoriamente reproduzindo o saber psiquiatra convencional, porque coloca os 
doentes apenas especularmente como o exemplo daquilo que ele estava lendo também nos manuais, mas nada contra a tradição da psicopatologia. Eu não tenho nada contra, cada vez, na verdade, acho que a psicopatologia tem uma contribuição sofisticadíssima para a reforma psiquiátrica. A boa psicopatologia, é a psicopatologia que tem que ser feita com os pacientes, com os usuários, com os familiares, que tem que se nutrir do conhecimento que é o conhecimento da experiência, que tem que se nutrir também de técnicas de pesquisas que são técnicas de pesquisa, por exemplo, de auto etnografia, onde os próprios pacientes podem ser, aprender e desenvolver a capacidade de construir a auto etnografia para que nós possamos melhorar esse conhecimento que produz autonomia e que sustenta a cidadania dessas pessoas que tem uma experiência radicalmente diferente de produção de subjetividade das pessoas que não passaram com a experiência da psicose, por exemplo. Então, calculando o meu tempo aqui, porque eu estou na parte do otimismo, está certo [risos].

Eu inverti, eu falei primeiro do otimismo, está certo? Porque eu tenho a impressão, não sei vocês vão concordar comigo, porque eu estou falando de uma maneira improvisada, só com uma anotação aqui, mas eu acho que tem um longo caminho andado, além do findos, manicômios horrorosos que foram mostrados aqui no relato do Domingos, não existem mais. Eu trabalhei numa instituição Colônia Juliano Moreira, que tinha 2500 pacientes internados, quando eu fui para lá. O tempo médio de permanência contado, havia uma pessoa que era um funcionário zeloso do arquivo e esse tempo médio de permanência era calculado de uma maneira bem precisa, não é um chute. $O$ tempo médio de permanência dos pacientes desse hospital onde eu trabalhei, era dez a onze anos de tempo médio de permanência, porque as pessoas entravam e não saiam. Então, essas instituições, elas foram substituídas por uma rede comunitária, com imperfeições. Hoje de manhã, uma colega me falou assim, eu não vi a resposta porque na hora eu tive que sair, mas e os CAPS e a cronificação dos CAPS e os pacientes dos CAPS que podem ser cronificados, sim claro, nós precisamos melhorar os CAPS, nós precisamos melhorar a clínica que nós fazemos nos CAPS, mas a resposta brasileira para o problema do mental health gap, para o problema da lacuna, Benedeto, eu acho que é uma resposta sustentada na lei 10.216, é uma resposta que se revelou efetiva e custo efetiva. Então são os CAPS, tratemos de torna-los melhores, mais efetivos. Vamos melhorar sim a clínica, como falamos, projeto terapêutico singular. Outro dia estavam discutindo um caso relacionado com CAPS infanto-juvenil, uma colega de fora pediu, "não deixe de falar sobre a parte da infância", então está bom, vou falar desses casos com problemas. O que se viu na discussão do projeto terapêutico de um adolescente com transtorno bipolar muito grave que sumia do serviço durante meses, reaparecia internado em uma emergência. 
Foi que o projeto terapêutico singular não conseguiu sair de dentro do CAPS para poder acompanhar um paciente que disse "eu não vou ao CAPS". Ora, a nossa concepção de CAPS, eu creio que é de todos nós, não é de um espaço físico rígido do qual as pessoas não saem, ao contrário, o CAPS é uma espécie de lugar geométrico das necessidades dos pacientes. O CAPS não é um edifício, se a equipe do CAPS não sai do CAPS, isso não é CAPS, e não venha botar a culpa na palavra CAPS, ou no dispositivo CAPS, vamos fazê-lo funcionar na sua plenitude, porque CAPS é apenas um nome do serviço comunitário de saúde mental no modelo adotado aqui no Brasil, não é isso? De interiorização e de absoluta interiorização. Então, como está caminhando para a parte final, o que eu queria dizer é que nós temos construído, não só no plano institucional, no plano normativo, mas também no plano do conhecimento, nós construímos um sólido avanço do campo decorrente da reforma e sustentado da lei 10.216. Então, de que forma que nós vamos agora, porque não adianta dourar a pílula, não adianta nós diminuirmos a gravidade do momento em que estamos vivendo. Aliás, eu não tinha visto a entrevista do Domingos, achei ótima, Domingos falou claramente isso. Domingos é tão otimista que eu achei que ele ia falar de uma maneira que não ia ser tão clara, porque ele é um profissional do otimismo. Não adianta dourar a pílula, não há reforma psiquiátrica sem um projeto de estado de bem-estar social com todas as dificuldades que ele tenha. Esse projeto de estado de bem-estar social, ele é sustentando, construído na constituição de 1988, quando se aprova no Brasil, se aprova pelo menos em primeira votação, desconhecendo completamente a resistência que se opôs. Porque nós não podemos mais falar, ainda bem, de uma letargia da sociedade diante do que se passou nesse ano de 2015. Está havendo resistência, as pessoas estão se organizando, mas com a absoluta indiferença e com uma repressão violentíssima que os meios de comunicação, de uma mídia que pertence a seis famílias, não divulga suficientemente, a violência da repressão que aconteceu ontem em Brasília, apesar dessa manifestação foi aprovada, em primeira votação, a tal PEC 55 que é uma desconstituição da constituição de 1988 no que se refere a políticas públicas, do que se refere ao mini estado de bem-estar social. E é um estado de bem-estar social em construção, imperfeito, nós sabemos que ele é imperfeito. Mas então não é possível ficamos pensando, figurando em torno de como vamos defender a reforma psiquiátrica, se nós não defendemos a ideia de um sistema universal de saúde. E universal é universal possível e em construção, que esse ministro da saúde atual, disse que é sonho de ideólogo.

Para você vê que tem sonho para tudo, eu citei aqui o sonho de Fernando Pessoa, você citou o sonho do Ledo Ivo e tem o sonho que utilizado como categoria de acusação, como categoria de invalidação, para dizer, falar em SUS, falar em sistema universal é sonho de ideólogo. Olha, se nós temos um ministro da saúde, um governo ilegítimo, 
mas é um ministro que é autoridade sanitária máxima, que diz que não é possível ter um sistema universal de saúde, que ele tem que ser substituído por uma mercadorização absoluta da saúde através de planos para pobres ou planos de saúde para pessoas, o principal enfrentamento que tem que ser feito é esse, me desculpe. Eu acho que a nossa reforma, a nossa resistência tem que enfrentar essa questão de fundo e a segunda questão que tem que enfrentar, o Sérgio Verani trouxe, é a questão do autoritarismo, que lançou a questão do estado de bem social. É a questão da desconstrução das fontes de liberdade, da liberdade do sujeito. É a desconstrução do estado democrático do direito, através da aprovação de sucessivas leis, sempre em nome do combate a corrupção, ou sei lá o que, que significam uma escalada nunca imaginada por nós Sergio Verani. Uma escalada da direita penal em proporções que nós não tínhamos imaginado Benedeto, aqui no Brasil. Sinceramente, não sei se outras pessoas previram isso. Então, nós estamos na construção de um estado, que é um estado privador de liberdades e ele não é privador de liberdades com tanques nas ruas. Ele é privador de liberdades com mecanismos perversos de deliquescência das convicções e da reflexão do cidadão e das pessoas, que é uma purificação contra todas as formas de corrupção. É a ideia de que tudo que é público e estatal é de baixa qualidade. É uma privatização desenfreada, entendeu? De bens públicos que vai, obviamente, convergir para uma desconstrução absoluta da ideia de estado de bem-estar social. Vocês viram que a parte pessimista é mais pesada. Ela é, digamos, a mais grave. Eu acho que é o seguinte, acho mesmo, sem muita certeza porque as coisas andam difíceis, eu acho que nós temos, digamos capital simbólico, experiência e história para resistir ao desmantelamento do estado democrático de direito, do estado de bem-estar social incipiente, que é em um estado em construção, ele é imperfeito, é obvio que é imperfeito. Então não estamos falando da sociedade socialista. Isso virá, se vier. Nós estamos falando de estado de bem-estar social.

Eu, por exemplo, há muito tempo, que já estou totalmente satisfeito se a gente construir o estado de bem-estar social, deixa o socialismo, se der vai ser ótimo, não é verdade? Mas no mínimo, que as pessoas não fiquem pela rua. Olha, nós fizemos um seminário há dois anos sobre a questão da reforma aqui no Brasil, sobre a questão do SUS. O primeiro quadro que eu tinha colocado lá foi o quadro do que se passou no Brasil nos anos 2000 há 2015, com a mortalidade infantil. Porque é um indicador excepcional, ele mostra uma coisa estrutural. Então a queda da mortalidade infantil do período de 2001 a 2002 até 2015 cobrindo, portanto, quatorze anos de governo social democrata, governo do... Desculpe, do PT é o nome do partido que estava no governo no país [risos], Lula, desculpe, é o nome do presidente da república [risos]. 
A queda da mortalidade infantil mostra uma operação estrutural que não pode ser negada e nem deve ser negada. Se você cai de trinta e seis para treze é uma queda "ah já vinha caindo nos anos 90", ótimo, vinha mesmo, porque, aliás, o programa da saúde da família é de 1994, governo do Itamar. O Itamar foi uma pessoa que construiu na verdade o programa de saúde da família já com o Adib Jatene e já com David Capistrano Filho. Você não pode atribuir só o programa de saúde da família, você tem que colocar também o Bolsa Família, você tem que colocar também a inclusão social, programa de renda, etc, mas é um indicador que é inegável para qualquer pessoa que trabalha, como o Benedetto, que trabalha com determinantes sócias em saúde. Então essa modificação que nós tivemos, ela é uma modificação que é, digamos, um saldo histórico a partir do qual nós temos que construir a nossa resistência. Ontem no debate a respeito do De Braços Abertos, eu acho que nós temos que caminhar também, por uma questão do De Braços Abertos para o segundo componente dessa nossa linha argumentativa da resistência que é o componente dos direitos humanos, dos direitos as pessoas, a elas sobreviverem na selva. Está bom, elas utilizam craque, elas fazem roubos, elas fazem não sei o que, mas elas não podem ser exterminadas.

Nós não podemos ter no Brasil 700 mil presos, dos quais setenta por cento são negros e pardos, dos quais mais de cinquenta por cento, em torno de sessenta por cento, tem entre 18 e 25 anos. Então tem alguma coisa que está profundamente errada na iniquidade social brasileira. Então não há como a saúde mental e a reforma psiquiátrica não enfrentar essa situação da iniquidade, da ética, mas também levando em conta o processo de construção de uma sociedade mais justa que vinha sendo feita. Então sendo assim, eu acho que a construção da resistência certamente não passa por câmeras de deputados, por senado federal, não passa por aí, mas passa sim... Hoje a Sandra Fagundes falou: pelo trabalho de cada um de nós, da micropolítica, estou de acordo totalmente. Número um, passa também pela construção de redes de resistência que incorporam governos municipais, governos estaduais, a gestão que se estabeleceu ao longo desse tempo e que tem consciência absoluta de que a proposta da lei 10.216 é altamente superior a todas as outras que vieram antes e que se propõem a vim depois.

Completando, será que é verdade mesmo que estão propondo acabar com a lei 10.206, acabar com a reforma psiquiátrica? Será que é verdade ou apenas é uma questão de ideologia, de não aceitar a diferença do campo político. Número um, discurso do ministro da saúde reiteradamente. Número dois PEC 55. Número três, recomendo a leitura, quer dizer, a gente lê cada coisa, como diz o Sérgio Verani, mas tem que ler cada coisa, recomendo a leitura do discurso do ministro do bem-estar social Osmar Terra, 
conterrâneo aqui da Sandra Fagundes, que é inacreditável uma pessoa que fez um diálogo durante um tempo com a política de saúde no governo Lula e que porque, por vários motivos, não sei quais, não interessa, mas também andou estudando tanta coisa cerebral, que ele começou a dividir os seres humanos entre pessoas que tem cérebros bons e cérebros ruins, porque o argumento que ele faz é sempre um argumento, assim, ao extremo do que nós chamamos de reducionismos biológico, mas é um reducionismos biológico grotesco do Osmar Terra. O discurso do Osmar Terra há duas semanas, no congresso brasileiro de psiquiatria é um discurso... E ele é uma pessoa que está falando pela saúde mental nesse governo Temer, não é o ministro da saúde, é um discurso onde ele propõe a desconstrução completa daquilo que se chama de reforma psiquiátrica. Como eles estão no governo, estão com poder e não há muita limitação, muita mediação institucional nesse momento em que nós estamos vivendo, eu acho que nós temos que levar a sério o fato de que a reforma psiquiátrica e a lei 10.216 está sob ameaça muito séria. E em homenagem à Fidel Castro: Hasta la Vitória Siempre! 


\section{Mesa redonda - Convenção dos Direitos das pessoas com deficiências e a lei $n .^{\circ} 10.216$}

Coordenação: Prof. a Dr. ${ }^{a}$ Márcia Aparecida Ferreira de Oliveira - Enfermeira, Professora Associada do Departamento de Enfermagem Materno-Infantil e Psiquiátrica da Escola de Enfermagem da USP

\section{Convenção dos Direitos das Pessoas com Deficiências e o Quality Rights - Prof. Dr. Roberto Tykanori Kinoshita}

Médico, Psiquiatra, Ex-Coordenador Nacional de Saúde Mental, Álcool e Outras Drogas do Ministério da Saúde do Brasil. Coordenador da Área técnica de Saúde Mental, álcool e outras drogas do Município de São Paulo, Professor adjunto da Universidade Federal de São Paulo - UNIFESP

Bom dia. Eu vou fazer uma introdução ...sobre a questão da convenção. Mas eu queria chamar a atenção para uma questão assim, uma introdução genérica, sobre a questão das leis, e eu estava vendo aqui uma instrução da convenção. Resumo, primeira coisa, a questão de lei natural, próximo (slide). A discussão de lei natural, é curioso porque a gente observa na natureza....

Todo mundo sabe o que é isso aqui? Sequência de Fibonacci. Assim, é uma sequência na qual o número seguinte é a soma dos dois anteriores. Essa é uma coisa que assim na natureza se observa, se identifica isso, essa sequência. São proporções, proporções que são consideradas assim como parâmetro do justo, do correto, do belo, serve para essa noção. E isso você vai observar em diversos fenômenos naturais que seguem essa lógica né. Isso por muito tempo foi uma referência. Aí, está Da Vinci, (slide)...para pensar a natureza e o homem como a justa medida das coisas. Então, esse imaginário de que a natureza, o certo, o correto e o justo, tem uma medida e uma proporção correta está impregnado na nossa cultura.

O que é o justo? O que é o belo? Existe uma proporção correta? Então, não sei se vocês já viram. Bom, justificativas do que é a beleza feminina nesse momento? Raças negras, orientais ou brancas, os padrões em tese são considerados os mesmos, só trocou 
a cor. E essa ideia é tão impregnada que a gente pensa assim "bom, a maior parte dos humanos está fora da lei, a maior parte dos humanos está fora da lei natural". De fato, na verdade, infelizmente, o Da Vinci pensava um ser humano, mas a gente na nossa prática, a gente vê esse ser humano. Esse é mais próximo daquilo que a gente vive no cotidiano. E a questão esse núcleo chama até cultural, emocional, porque é uma emoção quando você diz assim “O Homer Simpson é feio", ele está fora da ordem, está fora da proporção, está fora da norma, está fora daquilo que nós vamos entender como o belo, o justo e o correto, mas a grande maioria dos humanos se identifica mais com Homer Simpson do que com o homem de Da Vinci. Eu queria começar a partir daí porque quando a gente vai falar sobre a convenção, sobre os direitos da pessoa com deficiência, mais para a gente contextualizar. Essa convenção ela foi assinada pelos países membros da ONU no final de dois mil e oito e incorporada no Brasil através de um decreto à constituição brasileira. Essa é uma coisa curiosa, na verdade a nossa constituição de oitenta e oito ela previa que esses documentos internacionais que o Brasil assina deveriam ser todos incorporados na nossa lei, na verdade essa convenção foi a única de fato formalmente incorporada na constituição, integrada à constituição.

Então a convenção dos direitos das pessoas com deficiência tem para todos os efeitos no Brasil efeitos constitucionais, pode-se receber críticas dizendo que nossa constituição nesse momento não está valendo grande coisa, mas de fato a convenção faz parte e essa convenção veio derivada a partir da declaração universal de direitos do homem, então ela tem um fundamento anterior que é a declaração universal de direitos do homem. Antes, o tema deficiência, eu tenho feito muita encrenca por aí, por quê?

A convenção na língua portuguesa tanto no Brasil quanto em Portugal foi traduzida pelo termo deficiência, na língua inglesa, o debate internacional se deu em inglês, o termo é desability, e no campo semântico inglês desability já um neologismo, é uma construção de uma palavra nova, é um consenso de uma palavra nova para denotar um significado novo. E essa é uma das coisas a meu entendimento, por isso que eu arrumo encrenca, na conjuntura nacional dos movimentos sociais, das disputas internas dos movimentos sociais ligados às pessoas com deficiência acordou-se de adotar o termo deficiência, na verdade não é acordou, é manter o termo deficiência no texto assim como uma continuidade dos debates que haviam nesse campo. Isso traz para nós um problema, por que? Para nós, digo nós do campo da saúde mental, traz uma questão: o desability, um dos vetores das necessidades de um termo novo, ao menos se diz 'ametodicamente, que um grupo muito importante na produção desse texto foi um grupo americano dos survivors of psychiatry, sobreviventes da psiquiatria, que é um grupo de militantes or- 
ganizados, americano, que se designam sobreviventes da psiquiatria e participaram do debate da convenção dizendo que eles também querem fazer parte desse processo, da questão da convenção.

Então a deficiência traz confusão, porque tradicionalmente em inglês também deficiência mental é QI baixo, deficiência intelectual, literal, e não correspondia as questões que os sobreviventes da psiquiatria traziam, que são pessoas vindas do campo do transtorno mental, campo de drogas. Então, desability é um termo que surgiu na composição, um guarda-chuva maior que envolve literalmente as pessoas com transtornos mentais e problemas com álcool e droga; no brasil ficou como deficiência, isso traz um grande problema, inclusive político, em Brasília, nós tivemos lá algumas reuniões, algumas convenções públicas, parceiros, companheiros de outros movimentos, levantam e dizem assim "nós entendemos que as pessoas de transtorno mental não deveriam estar aqui", e não estavam mesmo porque não foram convidados.

Nós entendemos que a pessoa que usa drogas não deveria estar aqui, porque a pessoa que usa droga o problema dela é usar drogas, não é deficiente." Então isso traz um debate, trouxe no campo grande confusão, que é movimento das famílias com crianças autistas, porque nessa perspectiva conceitual eles lutaram, conseguiram se organizar para produzir uma lei que afirma que autismo é uma deficiência. Aí, cria-se uma confusão porque esses movimentos das famílias autistas dizem que autismo não é um transtorno mental, que é uma deficiência.

Aí é uma confusão, não é um transtorno mental então não devia ter psiquiatra, não, mas tem que ter psiquiatra. Quem atende? Quem cuida? Mas isso são decorrências digamos assim, muito confusas do campo e trazem operacionalmente para nós debates, debates não só conceituais, envolvem disputas de recursos, disputa de contratação de profissional, disputas inclusive no campo do exercício do direito; não sei se vocês já estiveram, deve ter tido situações, usuários nossos dizem assim "eu não quero, eu não sou deficiente, eu não quero ser acolhido na lei brasileira da inclusão", que é uma outra decorrência.

A Lei brasileira da inclusão está baseada na convenção e ela garante um conjunto de direitos. Ah, "mas eu não sou deficiente eu sou louco", ou o inverso a pessoa diz assim "não, mas eu quero ser reconhecido como deficiente, eu sou louco e deficiente. Eu quero os direitos, eu quero ter acesso, então muda meu diagnóstico." Aqui em São Paulo, especificamente, benefício do transporte de ônibus, chama assim; os requisitos são pensados a partir da convenção da SIF que é um dos pilares também da convenção, a questão do diagnóstico através do código de funcionalidade e não do CID. Os médicos 
não conhecem a SIF, dando diagnósticos, não conseguem permitir acesso aos nossos usuários, direito ao transporte público. Porque o requisito é que você descreva as disfuncionalidades das pessoas através do SIF e não através do CID, não adianta dizer "ah a pessoa tem esquizofrenia", esquizofrenia não quer dizer nada perante a SIF, então não permite acesso a diretos. Bom, o resumo desse tópico aqui é o seguinte: ou o campo da saúde mental que envolve álcool e drogas disputa, se apropria da convenção ou os nossos usuários saíram prejudicados.

Nós precisamos nos apropriar, entrar e fazer valer que a convenção, estou até quase desistindo de brigar para mudar a tradução, mas ainda não desisti disso não, porque a tradução nos prejudica, o conjunto do dobrado das leis civis, o código civil faz muita confusão ainda, o ordenamento legal ainda do que é deficiência é deficiência intelectual, ponto não tem outra, então você tem que chegar no advogado e dizer "não, olha existe a convenção que está na constituição entra com uma petição". Tudo se torna barreiras jurídicas para você conseguir fazer o exercício do direito que está inscrito, este que está editado, não é uma coisa inédita, está editado para publicar.

A convenção, o artigo primeiro traz uma discussão de definição diz assim: "pessoas com deficiência são aquelas que têm impedimentos de longo prazo de natureza física, mental, intelectual ou sensorial, os quais em interação com diversas barreiras podem obstruir sua participação plena e efetiva na sociedade e em igualdade de condições com as demais pessoas", eu acho que esse é o núcleo central de todo o espirito da convenção, detalhe - para alguns comentaristas que fazem a seguinte interpretação correta, diz assim “ essa convenção é um passo adiante em relação ao modelo de pensar as pessoas, a partir de um modelo estritamente biomédico" esse é um fato uma tentativa de superar o modelo biomédico, e vem dizer além do modelo biomédico agregam-se outros fatores das determinações sociais à questão da deficiência de uma pessoa. Isso traz uma ambiguidade digo assim, ao meu ver é uma fragilidade quase epistemológica, porque uma coisa é você tentar definir a situação a partir da somatória de atributos, um atributo biomédico, um atributo social, um atributo disso, um atributo daquilo, esse é um modo de tentar definir coisas, é uma somatória, a questão do indivíduo mais os elementos da sociedade. Eu acho que isso é uma interpretação frágil da ideia de desability no meu entendimento a gente precisa conceber não um somatório de atributos, tipo ele é esquizofrênico, pobre, negro, isso, mais isso, mais isso, mais isso, esse é um jeito de pensar, numa camada social $\mathrm{x}$, de uma categoria yz, quer dizer a gente faz uma somatória de atributos, ao meu ver não se trata disso, porque essa somatória de atributos é problema de aritmética, você soma e ponto final. 
A questão, que eu acho que é importante, é que esta definição ela sai da questão de uma lógica de atributos para se pensar em um objeto relacional, desability ou a tal da deficiência em português, não se trata de uma soma de atributos, mas se trata de uma avaliação de uma relação. Que relação? Primeiro, juridicamente a gente está discutindo uma pessoa, agora a constituição dessa pessoa, o entendimento sobre essa pessoa é uma avaliação de um indivíduo nas suas circunstâncias, na relação com a sua circunstância. A pessoa, ela tem que ser vista na relação, e a desabilidade é o produto dessa interação, indivíduo e circunstancias, numa certa relação, não é uma somatória, mas é uma relação, não é uma questão de soma, mas é uma razão. Por que que isso é importante? Porque isso dá lógicas operacionais distintas, se você pensar a equação $a+b+c$, para você equalizar ou é mais ou é menos, tendencialmente a sociedade faz equalizações tendem a fazer conta de menos, não faz conta de mais, nós entendemos assim, se o sujeito é menos então ele merece menos, porque ele faz menos, contribui menos, faz menos então tem menos.

Nossa tradição de conceito de justiça vem desse tipo de raciocínio, quem tem menos merece menos quem tem mais merece mais. E isso, a nós não nos interessa, acho que a constituição de oitenta e oito ela vem em diversos setores trabalhando a ideia de equidade, equidade não é, literalmente, uma questão de uma soma, mas equidade é uma razão, equidade não é $\mathbf{a}+\mathbf{b}$ ou $\mathbf{a}-\mathbf{b}$ é a sobre $\mathbf{b}$, uma razão. Porque que essa questão da razão é fundamental? Porque é a relação que determina a condição da pessoa. O sujeito em uma certa situação tem um termo, impedimento no seu corpo, agora a atuação deste corpo no mundo depende da suas circunstancias.

Quando eu tinha aula de genética um aluno, um colega levantou e falou assim “ah, mas professor me explica por que que então eugenia não é válida, a gente deveria eliminar pessoas que tem defeitos” então o professor levantou duas questões, primeiro a demonstração aritmética, aritmética não, matemática do quanto a penetrância dos genes tem uma certa diferença e como a capacidade de variação a partir de mutações é muito maior do que nossa capacidade de eliminação, então será um esforço perdido; a parte a isso, falou assim - além disso a humanidade tem alguns momentos históricos que mudam essa relação dos indivíduos no seu meio, por exemplo quantos míopes estão presentes aqui na sala? Vamos ver, levantem a mão os míopes. Aí esse meu professor falou assim "e a humanidade é tão sábia que consegue fazer dos míopes alguma coisa útil, tanto é que nessa sala muita gente é míope". Porque inventa um dispositivo que muda a nossa relação com as nossa circunstancias, ou seja, as nossas circunstancias são transformáveis a partir de um dispositivo relativamente elementar; Espinosa trabalhou muito tempo fazendo lentes para ajudar as pessoas a mudar a sua relação com 
o mundo. Esse aspecto é um aspecto essencial que a gente consiga incorporar, nossa tarefa a partir da convenção é fazer essa avaliação do indivíduo na sua circunstância e como a gente transforma essa circunstância, porque não basta, essa é a grande sacação, os indivíduos não são avaliados em si no éter, são indivíduos em um contexto com uma história, em um lugar, nas suas circunstancias, tem limites porque cada corpo é limitado, nós historicamente temos problema com nossas finitudes não é, é um tema filosófico milenar, nossas limitações, uns tem mais outros tem menos, mas todo mundo tem suas finitudes. Eu entendo que o reconhecimento da finitude, o entendimento da filosofia sobre a finitude é o que nos torna capazes de associarmos uns com os outros, porque ao reconhecer nossos limites e perceber o limite do outro também coopera a gente descobre na nossa história humana que juntos a gente supera nossos limites, que o que temos de mais comum entre cada indivíduo humano é que somos limitados e a superação do reconhecimento, a consciência dessa limitação nos permite compor, agregar, e superar a limitação de cada um, o famoso todos juntos somos fortes, somos mais que um monte de gente, somos mais que uma somatória de pessoas, agregados, reconhecendo o quão quantos somos mais.

Bom é nesse espirito que a convenção se organiza, eu vou saltar eu tenho quantos minutos mais? As outras definições leiam por favor. Existem alguns aspectos que eu destaquei que eu acho que vale a pena, o artigo três tem um item aqui, que diz assim "o respeito pelas dignidades inerentes a autonomia individual, inclusive a liberdade de fazer as próprias escolhas e a independência das pessoas”, depois vem: não discriminação, efetiva participação, mas o aspecto da autonomia individual inclusive a liberdade de fazer s próprias escolhas e a independência das pessoas, aqui na mesma frase agrega-se autonomia e independência, e para mim acho que essa é uma das questões também importantes porque a gente precisa refletir.

Muitos anos atrás tinha escrito essa questão, essa equação de que autonomia não é o oposto da independência, mas é ao contrário existe uma correlação entre autonomia e independência que é o seguinte, autônomo é o sujeito que faz a própria norma, faz a própria lei, essa capacidade de produzir as próprias normas, próprio modo rigorosamente aumenta, quanto maior as correlações e dependências que a gente gera. A autonomia das pessoas, dos indivíduos é maior quanto mais indivíduos ele está agregado e composto, porque nós, voltando a nossa finitude, nos impõe, nós dependemos uns dos outros, a primeira coisa; segundo se o meu grau de dependência é extremamente depositado em poucas relações, em poucos indivíduos, que aí é quantitativo, a dependência é concentrada em poucas relações minha autonomia é restrita, porque a minha capacidade de 
normatizar modos fica mais restrita, se eu tenho muitas relações das quais eu dependo, eu tenho um campo, um domínio de possibilidades, de variação muito maior. Eu acho que essa é uma das questões que a gente precisa raciocinar porque, novamente, como linha de pensamento, linha de trabalho, não adianta você falar assim "ah eu quero autonomia, eu quero independência, eu quero isso, eu quero aquilo" nesse sentido de afirmação de ideias de que pessoas, os indivíduos não necessitam uns dos outros, acho que esse é um grande equívoco, que autonomia ou independência caminha no sentido isolamento, novamente reafirmo aqui a ideia de que na espécie humana nós dependemos mutuamente uns dos outros e quanto mais formos capazes de compor com mais pessoas maior é a nossa autonomia e não o inverso. Acho que essa é uma questão importante. O tema especifico eu destaquei aqui, a questão das mulheres com deficiência, a maior parte aqui provavelmente é mulher. Tomaram todas as medidas apropriadas para assegurar o pleno desenvolvimento, o avanço e o empoderamento das mulheres, afim de garantir o exercício e o gozo dos direitos humanos e as liberdades fundamentais. Não precisa comentar, eu só destaquei porque na lógica, então se é assim não devia nem estar aí, porque somos todos iguais; é exatamente ao contrário, quer dizer se a gente conseguir superar essas situações de extrema desigualdade, de extremo desiquilíbrio, essas distinções são necessárias que sejam explicitadas, reafirmadas, porque se não a gente vai recair que não é necessário fazer mudanças, e é necessário fazer mudanças importantes.

A questão das crianças idem. Criança com deficiência tem direito a pleno exercício de todos os direitos humanos, liberdades fundamentais e igualdade de oportunidade para as demais crianças, direito de expressar livremente sua opinião sobre todos os assuntos que lhe disserem respeito, tenha sua opinião devidamente valorizada de acordo com a sua idade e maturidade. Essa ideia da relação dos adultos com as crianças também acho que é um aspecto que envolve mudanças conceituais, mudanças culturais importantes. Tomando assim um preceito antigo que se dizia o seguinte que quando você tem uma situação de desigualdade, de disparidade, de assimetria de poder, as pessoas que têm menos poder precisam ter mais direitos, essa é uma questão importante, porque as pessoas que têm menos poder têm menos direitos elas ficaram sempre submetidas a uma situação de submissão a quem tem mais poder. Então, a questão da infância está ligada a essa noção, se as crianças têm menos poder elas necessitam de maiores salvaguardas, de mais direitos. Esses direitos a mais precisam ser equalizados na relação. Essa ideia de igualdade não é uma igualdade aritmética, é simples pensar que igualdade é uma relação geométrica, igualdade $\mathbf{a}+\mathbf{b}=\mathbf{c}$ é uma coisa, aritmética, eu estou falando que é uma igualdade geométrica, é que a sobre b é igual a c sobre d, nesse sentido, existe sempre um denominador que modifica e equaliza a relação, isso eu acho que é importante na nossa 
construção cultural. O item doze é superimportante, é um tema polêmico e vou ter que encerrar, mas assim essa convenção ela propõe, ela supõe, coloca como premissa que as pessoas têm plena capacidade jurídica independente do grau de desabilidade.

Como assim? Plena capacidade jurídica independente da capacidade da sua desabilidade. Isso tem consequências para o modo da gente conceber as relações da sociedade, por que? A rigor isso colocaria fora das possibilidades, com algumas extremas exceções, a questão da interdição civil, parte do nosso campo. Porque as pessoas se consideradas plenamente capazes civilmente, e aí o que acontece com o sujeito? Ah o cara tem deficiência intelectual como faz? No debate produziu-se um conceito diferente, que é a ideia de que as pessoas que são plenas da sua capacidade, mas considerando as suas limitações elas precisam de apoio para tomada de decisões. Então a pessoa tem o direito de tomar decisões, de fazer escolhas, expressar a sua vontade, agora cabe ao Estado criar as condições para que essa decisão ela seja informada, contextualizada da melhor maneira, em tese.

Como que a gente vai fazer isso? Esse é um desafio social, cultural, você se na ideia de decisão apoiada, que o sujeito é um sujeito pleno civil e as suas decisões, levando em conta as suas limitações, requer que o estado institua um aparato em torno desse sujeito que lhe permita ser esse sujeito capaz e portanto para ele não sofrer desvantagens, para ele não estar submetido a desvantagem por falta de informação, a falta de capacidade analítica, o conjunto das suas limitações o estado deveria prover um aparato em torno ao qual, baseado no qual ele expressa as suas escolhas e as suas vontades, obvio isso traz questões de conflito de interesse, então esse aparato tem que ser, deveria ser instituído de maneira que não houvesse conflito de interesse, por exemplo herança, por exemplo bens, quem vai herdar e não vai herdar, por exemplo disputas familiares ou disputas pessoais. E acho que este é um dos temas importantes porque nos coloca um desafio como constituir isso, como gerar uma nova cultura, porque se faz uma contraposição de decisão apoiada em substituição, substituir aquilo que se chamava decisão substituta, um tutor, um curador, ele toma decisões substituindo o sujeito que tem limitações, no lugar dele. E a ideia da convenção é não haja alguém no lugar dele, mas que hajam pessoas que suportam esse sujeito na sua condição civil. Hoje colegas, companheiros de São Paulo, nós estamos tirando as últimas pessoas do hospital João de Deus, o município de São Paulo a partir de hoje não tem nenhum hospital psiquiátrico na nossa rede municipal total. Eu queria trazer essa questão aqui, para aproveitar que tem muita gente aqui da rede, eu queria dizer que este é resultado que não tem a ver comigo, eu cheguei tarde nessa gestão, isso também não é produto de um trabalho que se faz em 
poucos meses, na verdade é produto histórico de todos os trabalhadores de saúde mental do estado de São Paulo.

Quero homenagear todos os colegas, companheiros que trabalham aqui, porque no dia a dia eu sei que é muito difícil, tem muitas limitações, tem muitos sofrimentos, agruras do dia a dia, mas é que para um resultado desse talvez quem está lá na ponta, no dia a dia, não se dê conta do quanto essa somatória de esforços criou as condições para que o município de São Paulo não precise de manicômio. Assim, não vou dizer que nós temos uma rede excelente, todo mundo sabe que não está, nem uma rede suficiente, também sabemos que não é, mas esse esforço cotidiano de vocês conseguiu gerar na cidade, condições que não é necessário hospital psiquiátrico, acho que essa é uma demonstração intencional que nós temos hoje e isso é graças ao trabalho de todos vocês, por isso eu agradeço. Parabéns a todos.

Obrigado!

\section{Direitos dos usuários de serviços de saúde mental - Prof. Dr. Jefferson Aparecido Dias}

Procurador da República do Ministério Público Federal, Especialista em Direitos humanos, Membro da Red de Niñez y Adolescencia da Federación Iberoamericana del Ombudsman e da Comissão Permanente da Infância e da Juventude do Grupo Nacional de Direitos Humanos, do Conselho Nacional de Procuradores Gerais, Professor titular da Universidade de Marília - UNIMAR.

Um bom dia a todos e todas. É uma grande honra estar aqui, eu agradeço imensamente o convite. E eu queria falar com vocês sobre a situação do usuário. Eu vou aproveitar um pouquinho o que o Tykanori falou.

É interessante a Convenção, ela é um divisor de águas no que diz respeito à figura da pessoa com transtorno mental. Porque, até então, a legislação brasileira, ela trabalhava com essa pessoa, como quase que fosse uma pessoa não titular de direito. Não de um sujeito de direito. Mas muito mais um objeto direito. Era essa a lógica. Tanto que tinha a curatela como sendo algo para proteger essa visão. Ou seja, negava-se qualquer tipo de capacidade para essa pessoa com transtorno mental. 
A Convenção tenta mudar esse paradigma e reconhece em toda pessoa que tem capacidade em menor ou maior escala. E aí coloca em um plano secundário a lógica da curatela. Essa lógica inaugurada pela Convenção, ela passa a ser - já foi internalizada através de decreto - ela é reafirmada pelo Estatuto da Pessoa com Deficiência. Então, nós deveríamos ter então, a partir daí uma mudança de paradigma. Os juízes, os promotores deveriam atuar em face da pessoa com deficiência, com um outro perfil. Ou seja, fazendo curatelas em momentos única e exclusivamente necessários, no viés patrimonial, que seria essa a nova visão. E incentivando uma lógica de tomada de decisão apoiada. Então, estaríamos às portas do céu mesmo. Os anjos com as suas trombetas, as portas se abrindo e aquela visão maravilhosa do paraíso. Não foi bem isso.

Aqui o primeiro parêntese: é incrível como nós acreditamos nas leis. Porque na verdade, a gente acha que a lei é o fim. Ou o Direito é o fim. E nós não nos damos conta de que na verdade aqui nós estamos falando de bens. Estamos falando só de bens. Bens necessários para uma vida digna. Como que a gente atinge esses bens? Uma das formas de adquirir esses bens é por meio do direito. Então, na verdade o direito à saúde é o caminho pelo qual eu chego aos bens necessários para ter saúde. Mas essa construção mental, nós acabamos nos iludindo de que para acessar esse direito eu preciso de uma lei. E aí existe toda uma lógica legiferante. Então, eu crio uma lei que me garante o direito que permite eu acessar um bem. Não é? É isso. Só que nós nos perdemos nessa lógica e aí a gente começa a lutar só pela lei.

A lei já nos satisfaz. E essa lei, muitas vezes, sequer é posta em prática. Aí nós temos aquela: a lei para inglês ver. A lei que não pegou. E lamentavelmente, me parece que nem a Convenção pegou, lamentavelmente, e nem o Estatuto da Pessoa com Deficiência. Tanto é assim que já existe o PLS 757 de 2015, de proposta do Paulo Paim e Antônio Carlos Valadares, depois tem um substitutivo que é do Mário Mota, que já altera o Estatuto da Pessoa com Deficiência para proteger. Eu acho sensacional esse jogo de palavras. Para proteger a pessoa com deficiência. Para quê? Para proteger ela das escolhas. Porque pela legislação atual só seria o aspecto patrimonial. Mas ela precisa ser protegida no aspecto sexual, ela precisa ser protegida no aspecto pessoal. Ou seja, vamos negar a capacidade mais uma vez. Mas vamos lá: como está funcionando agora? Eu estou com alguns problemas lá em Marília.

Eu sou Procurador Público em Marília e sou Procurador Geral do Estado de São Paulo. Nós temos algumas pessoas com transtorno, que o judiciário exige que ela seja interditada para que ela possa buscar um benefício previdenciário no INSS. Ganhou na justiça. Então tem um saldo para receber. Tem lá 20, 30 mil reais de atrasados. Eu peço 
para o juiz federal remeter para a Vara Estadual, onde tem a interdição para quê? Para que o juiz estadual junto com o promotor estadual junto com o curador, estabeleçam como esse dinheiro vai ser utilizado no projeto de tratamento dessa pessoa com doença mental. Eu acho que é isso. Se esse dinheiro é da pessoa com doença mental, ele deve ser usado em prol dessa pessoa. $\mathrm{O}$ juiz estadual me devolve o processo falando o seguinte, olha: 'não, aqui eu não tenho mais nada. Aqui era só interdição. Eu já interditei, nomeei curador. Mandei para o arquivo o processo. Eu não preciso mais deliberar com relação à prestação de contas. Eu não preciso mais deliberar com relação ao tratamento. Não preciso mais deliberar com relação à curatela'. Só que a lei não dizisso.

A lei diz que o processo deveria continuar vivo. Para quê? Para que o curador prestasse contas do seu encargo. Para que pudéssemos monitorar essa pessoa com deficiência, essa pessoa com transtorno mental, para ver se ela já pode ter levantada a curatela. $\mathrm{Eu}$ ainda estou procurando um processo de levantamento de curatela. Porque eu vejo processos de curatela. E um número cada vez maior de curatelas. Nós estamos criando um exército de zumbis. Tem uma série que está na moda agora, que é The Walking Dead. Nós estamos criando zumbis. Mortos vivos civis. Não é? Eu me lembro de um evento que nós estávamos lá em Curitiba, eu falando sobre curatela. Um jovem lá no fundo levantou a mão e falou:' olha eu queria dar um conselho para vocês: nunca aceitem ser curatelados. Interditados. Curatelados'. Aí eu perguntei: por quê? Ele falou: 'não. O meu pai me convenceu que o bom seria que eu fosse para Universidade curatelado, só que hoje eu não consigo fazer nada, porque ele é o curador e decide tudo na minha vida, então não aceitem ser, eu acreditei que ia ser melhor para mim, mais não foi.' Veja a situação que nós estamos. Então, há na verdade, uma distorção e essa distorção, que pode ser pequena, tem gerado um exército de zumbis civis e, o pior, abusos. Não sei se todos conhecem um que sucedeu, está sucedendo em Sorocaba, é uma luta diária . Agora, todo mundo pode estar acompanhando, mas nós nos declaramos com a situação do que? Uma mesma pessoa, era curadora de duzentas pessoas. Uma! E onde é sensacional? Eram umas oitenta, mais ou menos. Uma vez por mês, ela ia lá pegava as pessoas. Levava para o comércio. Deixava comprar, fazer compras de apenas três horas. Pegava a nota fiscal? Não pegava nota fiscal, ou pegava a nota fiscal em branco. Decidia tudo na vida dessas pessoas, que só iam em algumas lojas, lojas que já tinham uma pré combinação. O pior de tudo, essa pessoa foi liberada, pelo judiciário, foi no Ministério Público, prestar contas, por causa de confiança, não precisava prestar contas. Recebia oitenta salários livres por mês, que não precisava prestar contas, o outro que ganhava duzentos foi até lá e disse: não, mais eu levo ele pra pescar, uma vez por mês, lá no pesque e pague. Esse era otratamento. 
Então veja, são abusos, abusos e abusos, que ocorrem sob as barbas das instituições, com o descumprimento da lei e sem que nada seja feito, quando surge um raio de luz, que seja o estatuto, ele é atropelado, pela prática diária, ele é atropelado pela postura conservadora, ou digamos, uma prática, que não busca qualquer forma, uma pratica emancipadora, uma pratica reguladora, que tenta manter os Estados pobres, teve uma que apresentou com tanta força que se propõe até mesmo a operação da lei, mas se voltar pra trás, né e aí o lamentável de tudo isso é que não vejo que estejamos fazendo algo diferente, lamentavelmente. Comecei a falar, entrei nessa área, há, há, Sorocaba foi quantos anos já, seis anos?. Dois mil e doze? Há quatro anos, os problemas que nós enfrentamos e voltamos a enfrentar são sempre os mesmos, de quatro anos atrás, as vezes eu leio algumas obras de um passado mais longínquo e eu vejo que os problemas ainda são os mesmos. Então, falar em tomar atenção apoiada parece algo ficcional, lamentavelmente, porque não é isso que nós vemos no dia-a-dia. Ainda, nos processos de interdição, os processos de curatela. Acho que vamos ter que mudar o paradigma, se nós não mudarmos as práticas sociais, pouco importa ter a convenção, pouco importa o que o estado está tendo de deficiência, pouco importa processos curativos. Então, tem que forçar para mudar a lógica, para que a pessoa com deficiência, com problemas mental, seja realmente recebida, que realmente nós a reconheçamos como uma pessoa titular de direito. Porque senão, continuarão a ser tratadas como objeto de direito, como algo que deve ser protegido, como se a curatela fosse uma forma eficaz de proteger a pessoa e não me parece. Você protege a pessoa quando você capacita, quando você a emancipa, quando você reconhece nela o diversos direitos, aí as curatelas tem que ser parciais, temporárias, excepcionais. Elas se tornam totais, permanentes, em regra.

Que regra? E o mais estranho é que isso está tão de forma naturalizado. Está de tal forma, que mesmo pessoas que deveriam tutelar um limite de pessoas, lutar pelos Direitos Humanos, quando se dão conta, tão trabalhando a favor dessa lógica reguladora. Eu tenho feito palestras em grupos com Defensoria Pública ou mesmo no Ministério Público, gente houve alguma interdição de curatela? Beleza, agora quem entrou com uma desinterdição, um levantamento de curatela? Ninguém levanta a mão, tá! Então veja, se a outra trabalhando com eventual exército de curatelados, interditados, eu tô colaborando com sistema, que reduz o ser humano ainda a um zumbi civil, um morto vivo civil. Então, o exército de 'The walkig Dead', que vem crescendo de forma assustadora, lamentavelmente. Somos só isso gente? Ainda acho que há, ajustamentos fiscais, capacitação de todos os setores, para fazer novas pericias, novos modos de fazer perícia, novas lógicas. Não é possível, que ainda se faça uma visitação, eu pergunto pra alguém que faz: a pessoa está apto pra usar atos da vida civil? Veja o que são atos da vida civil, então isso 
tem que mudar, não pode, se quer ser perguntado para um perito, . O perito não deveria aceitar a responder isso, ele fala: "olha, depende, atos da vida civil são esses, feliz na lei, então para esses sim, para esses não. Algo mais esmiuçado, temporário, daqui um ano, de seis em seis meses vão reavaliar, vamos levantar a curatela, vamos "desinfectar", isso é um segundo ponto.

E eu nem vou falar com as pessoas com problemas mentais, por incrível que pareça. Tem um quesito que eles colocam a pessoa: Existe alguma possibilidade dessa pessoa voltar a vir, em algum momento no futuro? É sensacional! Eu não sei se eu respondo. Se perguntar, você garante que nos próximos anos, de toda a sua vida até a morte, você nunca vai delinquir, dá? Não dá. Só que não embasa a resposta. O cliente fala corretamente: "não tenho condições de afirmar isso". O juiz fala: fica presa então! Porque ele pode voltar a reviver, na verdade, como anda o mundo acho difícil alguém não delinquir. Em alguns momentos, com a lei posta, eu acho que eu preciso ser classificado como delinquente. Um delinquente que acredita que a lei não é tudo. Um delinquente que precisamos passar a limpo uma lei. Se essa lei é restritiva. Se essa lei é, ela sim, uma violadora dos direitos humanos, porque aí é melhor agir contra lei, isso sim! Mas olha, no nosso caso não precisa nem ir contra a lei. Basta que a lei fosse cumpridas, bastaria que a nossa constituição, lamentavelmente, que tem sido atacada de forma brutal nos últimos tempos, que a convenção e que a lei do próprio Estatuto da Pessoa com Deficiência fossem cumpridos. O que que é isso? Vão perguntar, mais faz parte do jogo. Obrigado.

\section{CAPS e Quality Rights - Fernanda Nicácio}

Terapeuta Ocupacional, Professora do Departamento de Fonoaudiologia, Fisioterapia, e Terapia Ocupacional - FMUSP. Ex-Coordenadora Adjunta da Coordenação de Saúde Mental do Ministério da Saúde do Brasil.

Gostaria de cumprimentar a feliz oportunidade deste Encontro, destacando a riqueza de juntos pensar, de refletir coletivamente, de fazer em conjunto, de projetar, de conviver, em particular em "tempos tão difíceis"...

A realização deste Encontro é muito significativa neste momento, e estão presentes tantas e tantos companheiros desses anos, tantos jovens e também nossos mestres, Saraceno e Giovanna. 
Vivemos “tempos muito difíceis”..., não têm sido raras as ocasiões que sentimos uma certa perplexidade com o que está acontecendo nas terras brasileiras, e são muitas as indagações: Para onde vamos? Como vamos? Como vamos resistir? Resistir no sentido de agir em defesa da liberdade, da democracia, e resistir fortemente à restrição dos direitos conquistados.

Muitas análises têm sido desenvolvidas, tentativas de entender esses "tempos tão difíceis" e destaco uma dessas dimensões, isto é, a perspectiva de futuro que parece, neste momento, nublada, nossa projetualidade está turva... E nesses momentos de perspectivas nubladas, talvez, mais uma vez encontremos, mesmo que ainda distantes, a proximidade com as trajetórias institucionalizadas de vida e, talvez, exatamente por isso possamos, como ensinou Franco Basaglia, aprender com a "força dos loucos".

Para iniciar a reflexão, retomo sínteses das práticas desenvolvidas nesses anos: nos defrontamos com a força da resistência ao abrir as instituições; ao abrir as primeiras enfermarias, descobrimos o quanto os muros manicomiais concretizam saberes e poderes; ao "estar-com" os usuários, identificamos o quanto os territórios precisam ser desbravados; ao ensinar, dialogamos com a presença do senso comum em relação a qual lugar os loucos ocupam na nossa organização social.

Mas, também, nessas práticas, nas enfermarias, nos hospitais psiquiátricos, desde os anos 1980, percebemos a força das pessoas internadas, como estavam ocultos os projetos, as possibilidades das pessoas...; no cotidiano dos primeiros serviços 24 hs descobrimos a riqueza da potencialidade desse recurso; nos processos de ensino, reafirmamos a relevância dos percursos formativos de graduação, e o feliz encontro hoje, inclusive, neste evento, com tantos ex-alunos.

Nos percursos realizados, com tantas pessoas aqui presentes, pudemos encontrar, também, tantos movimentos com a mesma perspectiva ética, e destaco, em particular, o movimento da economia solidária e os diálogos com instituições que, em determinados momentos, pareciam tão complexas. Possibilidades de diálogos, uma vez que nossa bússola sintoniza com movimentos sociais e processos institucionais que buscam "construir um mundo melhor". Assim, na complexidade do momento que vivemos, são muitos os itinerários, e compartilho do que foi salientado ontem por tantos companheiros, da necessária luta em defesa da reforma psiquiátrica, do SUS e do Estado Democrático de Direito.

Por outro lado, em momentos como esse, a nossa utopia "Por uma sociedade sem manicômios" expressa, de forma ainda mais evidente, nosso compromisso ético, 
técnico, e político, com a liberdade, com os direitos, e com a democracia. Revisitando nossa história enfatizo, para a discussão de hoje, alguns momentos que expressam a força da defesa dos direitos e da liberdade no processo de reforma psiquiátrica brasileira. $\mathrm{Na}$ emblemática II Conferência Nacional de Saúde Mental, foi afirmada, de forma enfática, a diretriz de direitos de cidadania (Nicacio, 2003). O debate sobre a insígnia louco-cidadão foi particularmente aprofundado nos anos 1990, e me parece um momento fundamental para esse debate ser revisitado.

Em relação à discussão da liberdade, retomo algumas insígnias que atravessaram o processo da reforma psiquiátrica, citadas em trabalho anterior (Nicacio, Campos, 2007): III Conferência Nacional de Saúde Mental: "Liberdade é o melhor cuidado"; Congresso Brasileiro de CAPS em 2004: "Saúde mental: cuidar em liberdade e promover a cidadania"; Fórum Mineiro de Saúde Mental: "Liberdade, ainda que Tam- Tam”; Tykanori, final dos anos 1980, início da experiência de Santos: "Saúde mental: poder, afeto, e liberdade". Essas insígnias, produzidas na trajetória da reforma, expressam a nova ética que orientou os processos, a formulação de políticas públicas e o desenvolvimento de práticas; mas essa perspectiva não é simples: "cuidar em liberdade" se refere à transformação das instituições asilares, e, também, ao cotidiano dos serviços substitutivos, e produz quais significados no dia a dia dos serviços? (Nicacio, Campos, 2007).

Destaco a defesa de direitos e da liberdade na trajetória da reforma para, nesse momento, pensar o tema específico nesta mesa, CAPS e QualityRights, compreendendo os CAPS como lugares estratégicos para a superação do modelo asilar, e, assim, assume centralidade, a "produção de percursos que promovam, sustentem e viabilizem a afirmação da liberdade" (Nicacio, Campos, 2007), e, também, a promoção de "acesso e exercício de direitos" (Rotelli, 1999).

Convite para pensar essa questão em articulação e diálogo com a Lei 10.216/2001, tema deste Encontro. $\mathrm{O}$ Artigo $2^{\circ}$ apresenta, como salientado, um conjunto de direitos, e "ser tratada, preferencialmente, em serviços comunitários de saúde mental" como um direito; o Artigo $5^{\circ}$ aponta, claramente, a perspectiva da desinstitucionalização e da reabilitação psicossocial.

A partir desta breve síntese, as reflexões que apresentarei se inscrevem no processo de elaboração conjunta de um projeto de pesquisa, em boa companhia de pesquisadores, que cumprimento na pessoa de Sônia Barros, e, também, remetem às discussões que iniciamos quando estávamos no trabalho da Coordenação Nacional de Saúde Mental com a equipe coordenada por Tykanori, sobre o QualityRights. 
Em 2012, a Organização Mundial da Saúde lançou o projeto"WHO QualityRights" na perspectiva de, conforme indica documento da OMS (WHO, s/d), "unir e empoderar pessoas para melhorar a qualidade do cuidado e promover direitos humanos em serviços de saúde mental e de assistência social", e considerou para elaboração desse projeto, a necessidade de "um novo paradigma [...] serviços promotores de recovery que enfatizem [...] autonomia e participação dos usuários em todos os aspectos do tratamento e de suas vidas". O QualityRights tool kit tem como base a United Nations Convention on the Rights of Persons with Disabilities, no cenário nacional Convenção (2011) apresentada neste Encontro em várias discussões. Tendo com referência Artigos da Convenção, o QualityRights tool kit aborda cinco temas (Brasil, 2015):

1. "O direito a um padrão de vida e proteção social adequado", referente ao Artigo 28;

2. "O direito a usufruir o padrão mais elevado possível de saúde física e mental", referente ao Artigo 25 da Convenção;

3. "O direito a exercer capacidade legal e o direito à liberdade pessoal è̀ segurança da pessoa", referente aos Artigos 12 e 14;

4. "Prevenção contra tortura ou tratamentos ou penas cruéis, desumanos ou degradantes, e contra a exploração, violência e abuso", referente aos Artigos 15 e 16;

5. "O direito de viver de forma independente e de ser incluído na comunidade", referente ao Artigo 19 daConvenção.

No QualityRights, para cada um desses cinco temas, estão previstos padrões e critérios para avaliação. A Coordenação Geral de Saúde Mental, Álcool e outras Drogas do Ministério da Saúde apresentou, no site (Saúde Mental), a publicação da tradução oficial para português do QualityRights, e adotou, para o cenário nacional, a denominação: "Direito é Qualidade". De acordo com a referida apresentação: “O componente inovador consiste na perspectiva de promoção da qualidade em serviços de saúde mental enquanto garantia de direitos de seus usuários”. Enfatizo a relevância dessa inovação em termos de avaliação de serviços: a perspectiva de qualidade compreendida como direitos dos usuários, garantia e promoção de direitos. Naquela oportunidade foi disponibilizado o conjunto de cinco ferramentas do QualityRights tool kit (Brasil, 2015): o documento geral de apresentação do conjunto do instrumento; a Ferramenta para Entrevistas; a de Análise de Documentação e Observação; o Relatório de Avaliação nacional; e o Relatório de Avaliação com base no serviço. 
Certamente são muitas as questões a serem discutidas, mas neste momento gostaria de trazer algumas contribuições para pensar em conjunto a proposição do QualityRights e os CAPS. Nessa perspectiva, retomo as questões assinaladas anteriormente - "afirmação de direitos, promoção de direitos" e "cuidado em liberdade" que configuram bases e diretrizes da reforma psiquiátrica, presentes na prática cotidiana dos serviços, assim como na formulação de políticas públicas - e, nesse sentido, considero que a possibilidade de diálogo CAPS e QualityRights pode gerar um potente encontro. Claro que potente encontro a depender do processo que será desenvolvido em relação ao QualityRights que pode produzir uma provocação, provocação aqui no sentido de instigar a reflexão conjunta sobre violação e restrição de direitos, e, também, sobre as experiências de "acesso e exercício de direitos", e com essa perspectiva cultivar, coletivamente, o CAPS como lugar de promoção dedireitos.

Assinalo, então, três questões para pensar junto. Primeira questão: como abordado anteriormente, a Convenção tem sido pouco apropriada no nosso campo; por outro lado, se retomarmos o propósito da Convenção (2011), conforme Artigo $1^{\circ}$, de "promover, proteger, e assegurar o exercício pleno e equitativo de todos os direitos humanos e liberdades fundamentais por todas as pessoas com deficiência e promover o respeito pela sua dignidade inerente", e a análise da trajetória da reforma verifica-se que a premissa da Convenção é presente no processo de reforma. Assim, a Convenção constitui e, em particular nesse momento, pode ser um instrumento bastante importante; nesse sentido, como salientado, é muito importante que o nosso campo possa se apropriar da Convenção.

A segunda questão refere-se ao tema, relativos aos Artigos 12 e 14 da Convenção, "o direito a exercer capacidade legal e o direito à liberdade pessoal", assinalados anteriormente neste Encontro. O cotidiano nos serviços, não só nos hospitais psiquiátricos, mas também nos CAPS, é a presença de pessoas interditadas; cabe ressaltar, também, a complexidade, no dia a dia dos serviços substitutivos, de trabalhar, de operar na prática cotidiana compreendendo as pessoas como "sujeito de direitos". E exatamente por essa complexidade é importante aprofundar a reflexão, uma vez que, de certa forma operam, no cotidiano, muitas armadilhas ao considerar que as pessoas não são capazes, que as pessoas não são capazes para o diálogo, para efetivamente participar. Se, por um lado, a discussão sobre violação de direitos é muito mais evidente, por outro, como operar cotidianamente, e considerando os CAPS para reflexão, com as pessoas compreendidas como "sujeito de direitos" é muito maiscomplexo.

Em relação à relevância da proposição de "capacidade legal", como apontado anteriormente, poderíamos pensar em começar a produzir práticas de “Tomada de Decisão 
Apoiada" (Brasil, 2015); nesse sentido inclusive, recordo do trabalho anterior em Sorocaba, de discussão de como produzir práticas concretas de “Tomada de Decisão Apoiada”, como iniciar práticas concretas nos CAPS, de buscar levantamento de interdição, construindo diálogos com o conjunto de instituições. E, também, como compreender "Tomada de Decisão Apoiada”, sintética e valiosa expressão, no cotidiano das práticas terapêuticas, isto é, quais são os desafios das práticas cotidianas nos CAPS para que seja possível, no campo do cuidado, operar, efetivamente, com essa perspectiva de constituir as equipes, os CAPS, os recursos, como apoio para propiciar, às pessoas com experiência de sofrimento psíquico, novas possibilidades para seus projetos de vida.

Considero que esse tema do QualityRights, com padrões e critérios, pode contribuir como uma estratégia nesse processo de olhar nossas práticas, de pensar em conjunto, de encontrar estratégias, de pensar práticas concretas, porque é claro que se trata, como assinalado, de uma profunda mudança cultural, jurídica, técnica.

A terceira questão para essa reflexão, é o tema do QualityRights relativo ao Artigo 19 da Convenção, que se refere ao "Direito de viver de forma independente e de ser incluído na comunidade". Tema muito claro em todo o processo de reforma, da garantia desses direitos; mas, também, é importante refletir no cotidiano das práticas como tem sido o desenvolvimento de processos que operam no sentido da articulação do apoio efetivo para garantir os direitos ao trabalho, à moradia, e à participação social.

Por essa razão, mais uma vez, penso que o QualityRights pode ser uma estratégia de reflexão sobre como têm sido as práticas de restituir, de promover, de articular "o acesso e o exercício de direitos" (Rotelli, 1999). Em outras palavras, refletir sobre como os CAPS têm operado esse desafio complexo, e tendo como referência as contribuições de Saraceno (1999) e Rotelli (1999) para pensar os processos de reabilitação, citando Rotelli (1999) "construir (reconstruir) acesso real aos direitos de cidadania, o exercício progressivo dos mesmos, a possibilidade de ter reconhecidos esses direitos e de agir, a capacidade de praticá-los".

Para finalizar: os cinco temas, padrões e os critérios do QualityRights certamente abrem um conjunto de reflexões que podem contribuir, podem gerar um potente encontro, QualityRights e CAPS, para a reflexão da prática e a afirmação dos CAPS como "lugares de promoção de direitos".

Claro que ao referir os CAPS, as práticas cotidianas de liberdade e direitos, estamos, evidentemente, discutindo instituições e poder, restituir poder, ampliar poder, fortalecer poder (Saraceno, 1999; Rotelli, 2016). Temos uma extensa literatura sobre o 
lugar do manicômio nas relações sociais, e parece fundamental aprofundar a reflexão sobre o lugar dos CAPS nas relações sociais - e considerando a promoção de liberdade e de direitos, e a restituição e o fortalecimento de poder das pessoas que vivenciam a experiência de sofrimento psíquico, poderíamos refletir sobre a perspectiva dos CAPS, na singularidade do desafio de sua responsabilidade e de seu lugar social, como uma das instituições que compõe a democracia cotidiana e os percursos de ampliação de direitos a partir do cotidiano.

Nesse sentido, um convite para o próximo Encontro com o tema dos CAPS como um dos lugares fundamentais na produção da democracia do cotidiano; próximo Encontro, considerando, de acordo com nosso grande poeta: "Amanhã há de ser outro dia". 


\section{Mesa redonda - As estratégias e instrumentos de inclusão social e os direitos das pessoas com transtornos mentais em conflito com a lei}

Coordenação: Prof. Dr. Jandro Moraes Cortes - Enfermeiro, Professor Doutor do Departamento de Enfermagem Materno-Infantil e Psiquiátrica da Escola de Enfermagem da USP.

\section{Programa de atenção integral ao paciente judiciário portador de sofrimento mental (PAI- PJ) Minas Gerais - Dr. ${ }^{a}$ Romina M. de Magalhães Gomes}

Psicóloga Judicial do Núcleo Supervisor do Programa de Atenção Integral ao Paciente Judiciário (PAI-PJ) vinculado ao Tribunal de Justiça do Estado de Minas Gerais, Doutora em Psicologia pela Universidade Federal de Minas Gerais.

Boa tarde a todos e todas. Eu gostaria de agradecer em primeiro lugar à doutora Sônia Barros pelo convite para estar aqui hoje. É com muita satisfação que eu tenho falado um pouco do programa de atenção integral ao paciente judiciário do tribunal de justiça de Minas Gerais. Eu gostaria de parabenizá- los por esse encontro, pela iniciativa de colocar em discussão esse tema em um momento tão delicado pelo qual passa o nosso país, pois nós nos encontramos à beira de um imenso retrocesso. Sobretudo no que se refere às políticas públicas e à manutenção dos serviços de saúde mental.

É um grande desafio avançar quando os recursos encontram-se sob ameaça de serem retirados. Mais do que nunca a gente precisa tornar vivo esse debate, essa discussão. Então, eu pretendo trazer para vocês um pouco da experiência do PAI PJ que é um programa do tribunal de justiça de Minas Gerais sobre o viés da inclusão social e dos direitos das pessoas que apresentam sofrimento mental e que cometeram um ilícito penal. Para alcançar esse objetivo, eu vou retomar brevemente alguns aspectos que se encontram na gênese da medida de segurança, que é a sentença aplicada aos loucos infratores. Para tentar recuperar um pouco a complexidade dessa questão. 
Robert Castel é um autor francês que nos ajuda, ele nos dá algumas pistas para nós iniciarmos essa tarefa de recuperar esses pontos, esses fundamentos que estão na base da medida de segurança. Ao nos apontar que com a invenção do estado moderno, conseguido a partir dos ideais de igualdade e liberdade que alimentaram a revolução francesa, colocou-se a questão de não se poder tomar o louco como igual. O estado moderno se edificou então sobre o sistema contratual por meio do qual os cidadãos foram tomados como soberanos. Mas também, foram tomados então como soberanos, mas também sujeitados aos deveres que deveriam assumir, sob pena de receberem uma sanção repressiva. Ao mesmo tempo, os cidadãos poderiam participar das atividades subordinadas à lei, de onde retirariam os seus direitos que definem a sua liberdade.

Apesar da igualdade de direitos pertencer a uma dimensão puramente formal, considerou-se que determinada categoria de indivíduos não poderia fazer parte, sem problemas, desse sistema contratual. O problema colocado pelo louco se distinguiu por seus crimes não oferecerem nenhum vínculo racional passível de reunir a transgressão das leis à repressão. Se buscava um vínculo que pudesse justificar a repressão, vinculando à transgressão da lei. O que motivou esse sujeito a cometer esse crime? Então, esse vínculo era buscado nos motivos, nas razões do crime. E os crimes cometidos pelos loucos, na virada do século XVIII para o século XIX, na época da revolução francesa, eles eram chamados de crimes imotivados, ou crimes sem razão. Porque eram crimes bárbaros, muito graves, essas pessoas foram muitas vezes tomadas como monstros, porque chegaram a cometer crimes tão graves, e muitas vezes esses crimes atingiam ascendentes ou descendentes, então iam contra a natureza humana. E por esse fato eles começaram a se perguntar quais seriam os motivos e não se via ali um vínculo racional passível de justificar a punição aquelas pessoas.

Então, a solução encontrada, Robert Castel é quem vai nos dizer, a partir da intervenção do discurso psiquiátrico, foi a de submeter o louco ao tratamento, ao invés de submetê-lo a uma pena. Ainda que esse tratamento representasse também uma espécie de penalização. Entretanto, essa sanção só poderia subsistir de modo disfarçado, justificada pela racionalidade terapêutica. O louco foi então retirado do guarda-chuva formal da igualdade de direitos que funda a democracia moderna, e foi então entregue à psiquiatria para realizar a sua gestão.

A psiquiatria, Castel vai focar isso, nasce então em resposta a um problema de governo, para responder a um problema de governo, apesar de ter justificado como estritamente técnica o seu campo de intervenção. Quem vai ocupar esse espaço então, é a psiquiatria que surge com Pinel, a chamada medicina mental, no início, a psiquiatria não 
era chamada como tal, era nomeada medicina mental, e Pinel e seus discípulos irão então propor que o louco deveria alojar em si o mal, ele seria portador de um déficit moral que o tornaria incapaz de responder por não poder controlar a própria vontade, então as suas ações, segundo esses autores, os discípulos de Pinel, seriam determinadas pelo instinto, força irresistível que age no sujeito, em detrimento do que ele possa querer, o instinto seria capaz de se sobrepor e anular toda a vontade produzindo um impulso irresistível ao ato violento, desse modo o louco foi concebido como perigoso devido à imprevisibilidade e a impulsividade que lhe foram atribuídas desde então, partindo do início aí do século XIX, com a formulação de Pinel e seus discípulos até chegar em Lombroso. Essas concepções fizeram com que o poder judiciário recuasse em sua tarefa de convocá-los a esse momento pelos atos cometidos e os entregassem a psiquiatria criminal para realizarem a sua gestão, com a proposta de estabelecer uma vigilância contínua dos loucos; em um espaço vazio a psiquiatria então assumiu esse lugar, de administrar a loucura.

É com a síntese dessas ideias que nasceram com o Pinel, que foi empreendida depois por Lombroso, e a criação da escola criminal positiva, a concepção de uma periculosidade intrínseca ao homem foi difundida, de acordo com essa perspectiva determinista, mecanismos de controle foram criados, visando defesa social, e a precaução contra os riscos envolvidos na convivência com a loucura, a presunção de periculosidade que implica atribuir ao louco infrator um risco virtual futuro, de cometer novas infrações penais fez surgir a ideia de um dispositivo de controle e segregação específico no manicômio judiciário. Aí essas ideias então foram difundidas no Brasil a partir do século XIX, na virada do século XIX para o século XX, alguns autores que se destacaram aí, sobretudo; Nina Rodrigues, Franco da Rocha, Heitor Carrilho, e o sistema de isolamento do louco em manicômios judiciários foi incorporado à legislação. Com o código penal de 1940 surgiu a medida de segurança com o instituto jurídico, no ordenamento jurídico brasileiro, e nessa época, então, já em 1940, a medida de segurança já possuía a característica de ser por tempo indeterminado, ou seja, sem limite temporal, só podendo ser extinta pelo exame de cessação de periculosidade feito pelos peritos psiquiatras.

A história mostra que esse dispositivo jurídico psiquiátrico continuou a permitir o isolamento e a manutenção da sanção penal por tempo indeterminado, e em muitos casos durante toda uma vida, pois os loucos vias de regra, eram tomados como intrinsecamente perigosos.Com a reforma psiquiátrica e o surgimento da luta antimanicomial na década de 1980, no Brasil, os absurdos que aconteciam no âmbito da atenção a loucura começaram a se tornar visíveis e questionados como todos vocês sabem, nós estamos aqui hoje justamente comemorando e tentando avançar nessa questão, passaram então a ser 
amplamente questionados, e a Lei 10.216 veio redirecionar o modelo de tratamento no plano da psiquiatria, mas há ainda um fosso que separa a aplicação dessa lei, e a legislação penal relativa a pessoa em situação de sofrimento psíquico, é o que programas como o Pai-PJ tentam tratar, cuidar dessa questão para tentar diminuir esse fosso e tentar levar a lei 10.216 para ojudiciário.

Bom, isso se repete, não só esse fosso que existe entre a legislação penal e a lei 10.216, se repete também com relação a Constituição Federal e a Legislação Penal, cujos preceitos são continuamente ignorados e desrespeitados, no que diz desrespeito a aplicação da medida de segurança, o princípio constitucional da dignidade da pessoa humana é continuamente ferido com a aplicação dessa sanção penal, sobretudo, devido a essa etiqueta de perigoso que nasce lá no século XIX a partir do surgimento da medicina mental, essa seria, vamos dizer assim, a pior, a mais cruel, e equivocada nomeação que poderia ser dada a alguém, essa de perigoso, outra nomeação que frequentemente lhe é atrelada, que o doutor Jefferson recuperou aqui hoje de manhã para nós, é a de incapacidade, é tão nefasta quanto, e que os próprios portadores de sofrimento mental recusam, se a gente for lá nos sanatórios, nas conferências de saúde mental, a última conferência de saúde mental, a gente vai ver essa recusa, isso foi registrado no relatório dessas nomeações de perigoso e de incapaz. Então, todas essas nomeações apontam para um desprezo da palavra, da pessoa em situação de sofrimento psíquico submetida a sanção penal.

Podemos falar nesses casos em igualdade de direitos? Em dignidade da pessoa humana?

A lei 10.216 vem permitir, dentre outras coisas, que reconheçamos todos que a internação por tempo indeterminado, e muitas vezes perpétua, representa uma incomensurável violência aos direitos fundamentais dos portadores de sofrimento mental. Então, eu vou passar a proposta do Pai-PJ, tentar mostrar para vocês qual seria essa alternativa que é proposta pelo programa de atenção integral de paciente judiciário, como é que se aborda essa questão da periculosidade, da incapacidade, da inimputabilidade, que seria de certo modo considerado como incapaz de responder pelos seus atos, inclusive os atos que resultam em processo criminal, então eu vou procurar mostrar para vocês um pouco do que é esse trabalho.

O Pai-PJ surge a partir de uma pesquisa realizada pela Fernanda Otoni, que é uma psicóloga judicial, psicanalista, professora universitária, que em 1999 iniciou uma pesquisa com relação a esses casos, que eram submetidos a certeza da medida de segurança, e a partir desse projeto de pesquisa em 2000 foi proposto um projeto piloto que começou, 
então, um acompanhamento de casos, na comarca de Belo Horizonte. Esse projeto ele começa em um momento em que Belo Horizonte passava pela reforma psiquiátrica, pela substituição dos serviços de saúde mental, criação dos CAPS, e lá nós temos a nomeação do CERSAM; então os hospitais psiquiátricos começaram a receber casos apenas daqueles lugares em que ainda não haviam CAPS, não tinham ainda uma rede estruturada, que não podiam então oferecer um tratamento de crise, ao passo que os juízes começaram a determinar, por falta de vaga em manicômios judiciários, a internação dessas pessoas que recebiam a sentença de medida de segurança, que cometeram um crime e tinham sofrimento mental, começaram a determinar que essas pessoas fossem para os hospitais públicos psiquiátricos, e isso gerou uma grande crise, um grande descompasso, e nesse momento dessa crise então, surge a proposta desse programa que vai então tratar de um modo distinto, dessa questão. Desde 1995 em Minas Gerais, existiu a lei 11.802 que é a chamada lei Carlão, que é a lei da reforma psiquiátrica estadual de Minas Gerais, então a partir desse momento os serviços substitutivos já existiam, toda a política estava sendo redirecionada, em 2001, juntamente com a lei 10.216, o Pai-PJ então se tornou um programa, porque até então era um projeto piloto, mas era um programa restrito a comarca de Belo Horizonte.

No ano de 2010 o Tribunal de Justiça entendendo que essa política deveria abranger todo o estado de Minas Gerais criou a resolução 633 que passou a regulamentar o trabalho que programa no estado de Mina Gerais, dentro desta resolução existe a definição do que é o público do programa Pai-PJ, então nós encontramos lá no artigo $7^{\circ}$ da resolução 633 o que é um paciente judiciário; seria então qualquer pessoa em situação de sofrimento psíquico que seja indiciado, réu, ou sentenciado em processo criminal, ou adolescente autor de ato infracional, esse é o público do programa. Se a gente for olhar assim, a gente pensa que é muito amplo, as pessoas muitas vezes confundem um pouco, pensam no conceito ampliado, o que é o sofrimento psíquico, a gente tende a restringir aos casos de psicose, que tem esquizofrenia, transtorno bipolar, então são aqueles casos muito graves da saúde mental, o público dos CAPS, que são pacientes do Pai-PJ.

Qual que é a função do programa?

A Fernanda Otoni propõe que a função primordial do programa é de ser um dispositivo conector, que articula os diversos setores envolvidos na atenção ao público infrator visando promover sua inserção social, a sua responsabilização, e o seu tratamento, além disso o programa auxilia juízes criminais informando sobre o cumprimento da medida de segurança, possibilitando a sua individualização, sempre considerando a singularidade de cada caso. 
A equipe do programa é composta por psicólogos, assistente sociais, e assistentes jurídicos, essa equipe tem a função primordial de acompanhar os casos privilegiando a escuta do detalhe próprio a cada sujeito, e articular as redes de atenção orientados sempre pela singularidade de cada um. Eu vou passar a falar sobre os princípios orientadores deste trabalho, porque eu acho que é fundamental trazer um pouco para vocês o que é que nos orienta, e vai fazer um gancho com aquelas ideias que eu trouxe no início com a introdução, vocês vão entender como que o Pai-PJ se posiciona com relação a essas várias construções que fazem parte hoje do imaginário social; o primeiro deles diz respeito a questão da periculosidade, no lugar de presunção de periculosidade a proposta do programa é a presunção de sociabilidade, o que seria isso? Seria então tentar subverter a presunção de periculosidade e das práticas de segregação, o estabelecimento de uma nova política no campo da saúde mental, com a implantação dos serviços substitutivos ao manicômio, permitiu que essa proposta fosseconcretizada.

O grande desafio para nós, o tempo inteiro, é de abrir espaço no tecido social para fazer caber as diferenças, porque existe um imaginário social de que essas pessoas que cometem crimes muito graves, elas tem que ser segregadas, elas são de fato perigosas, elas são de fato imprevisíveis, impulsivas, então a resposta a isso seria a segregação, ao passo que quando a gente começa a ver de perto os casos, conhecer cada sujeito, poder falar, a própria rede às vezes recebe com um certo temor, como que a gente vai receber esses casos que cometeram crimes tão graves, o que é que essa pessoa pode fazer aqui dentro, então quando se começa a falar sobre os casos a coisa se desloca e as pessoas começam a perceber que se trata de uma pessoa em sofrimento como outra qualquer. O segundo princípio orientador é a questão da responsabilidade, seria também uma subversão da inimputabilidade e da incapacidade de resposta que foram atribuídas ao louco infrator pelo direito e pela a psiquiatria; nós consideramos, então, que todo o ser falante, todo sujeito é capaz de responder, é capaz de inventar algo para tratar o seu sofrimento, essa é a resposta que o programa busca, eu coloquei ali uma referência a um psicanalista, que é o Jacque Lacan, que vai trabalhar a questão da responsabilidade na loucura, não sei se vocês já tiveram a oportunidade de ter contato com o seminário vinte e três, do Lacan, não é um livro exatamente muito fácil, mas vale a pena a gente perceber como que o Lacan aborda e nos mostra ser possível pensar a loucura como responsável, porque todo mundo responde ao sofrimento, todo mundo elabora uma resposta ao encontro com a angústia, com o que faz sofrer, e os outros não seriam diferentes, todo ser humano é capaz de resposta.

O Terceiro princípio orientador, é um tratamento orientado pelas singularidades, é fundamental, esse é o eixo do programa, cada sujeito com suas peculiaridades, com o seu 
modo único de responder ao mundo e ao outro orienta o tratamento; essa metodologia operam uma subversão para a abordagem do sofrimento mental feita pelo viés da psicopatologia, as invenções de cada sujeito para tratar o sofrimento são elevadas a agilidade de uma orientação no tratamento. O quarto princípio eu vou correr um pouco porque já está terminando o tempo, depois a gente pode ter tempo para conversar, o trabalho em rede, fundamental para o nosso trabalho, Pai-PJ só existe porque existe uma rede de saúde mental estruturada, no Brasil, ou digamos assim em processo de estruturação, e a gente trabalha juntamente com essa rede, com uma parte dessa rede, então essa prática é feita com muitos que se dispõem a deixar de lado o seu saber especializado para se orientar pelo saber do sujeito.

O trabalho acontece em rede com sua horizontalidade, diferente de um trabalho hierarquizado, um saber acima de outro, e por cima do outro, é a rede como vocês sabem, ela funciona em uma horizontalidade com várias entradas possíveis, e é a rede que é tecida pelo sujeito. Isso faz toda a diferença, o que é a rede de saúde mental para um determinado sujeito, é a rede que ele teceu, então a gente às vezes cria um serviço, abre a porta, e chama o sujeito, e convida ele a se adaptar ao que a gente propõe, não é bem essa a proposta, porque a gente começou a perceber que essa questão da adaptação do sujeito ao serviço não trata exatamente do que a gente estava desejando propor, então a gente é que vai tentar chegar nesse sujeito com uma oferta de algo que faça sentido para ele, que possa provocar um vínculo, nós é que vamos atrás desse sujeito, vamos correr atrás, então não é o sujeito que vai aderir, é nós que vamos aderir a ele, então a gente é que vai tentar produzir aí essa rede de acordo com que ele está acoplado. E, essa rede ela inclui, a saúde mental, ela inclui a justiça, o juiz passa a fazer parte dessa rede, a defensoria pública, a promotoria, as diversas ofertas que uma cidade pode fazer no campo do trabalho, de cursos profissionalizantes, então é uma rede a mais ampliada possível segundo o que cada sujeito aponta. E o quinto princípio orientador é o ato jurídico como operador clínico, essa foi uma grande descoberta da Fernanda Otoni desde o início do programa, ela começa a perceber, que as pessoas tem um certo endereçamento a justiça, que supõem que a justiça vá ajudá-los a regular o seu sofrimento, a tratar o que está fazendo sofrer, então a gente valoriza esse ponto aí da vinculação a justiça, o tratamento então por se articular ao ordenamento jurídico abre a possibilidade de recurso as ficções jurídicas, a convocação do sujeito para responder pelo seu ato fora da lei não é sem consequências, quando ele percebe um chamado da justiça, quando um cidadão em sofrimento mental recebe um chamado da justiça ele, o que a gente vê assim na grande maioria dos casos, é uma prontidão em responder, "Ah, o juiz me chamou, o promotor está dizendo para eu tratar ", etc, passam então a responder esse chamado, a construir uma resposta 
orientada pela lei, as menções jurídicas podem então funcionar como operador clínico, favorecendo a estabilização, e a construção de novas respostas que são compatíveis com o laço social, isso faz toda a diferença em um programa como Pai-PJ.

Eu não sei se dá tempo de eu, estou com alguns fragmentos de casos, vou passar um ou dois rapidinho aqui, só para vocês terem ideia, o que é esse lugar que essas pessoas atribuem a justiça, ao direito, e se torna então um recurso, um recurso que auxilie no seu tratamento, o direito como parceiro do sujeito, o campo da justiça se torna então o lugar privilegiado de para os pacientes judiciários que vivenciam o caos subjetivo, a função reguladora do direito destaca-se de modo contundente no acompanhamento de pacientes judiciários pelo Pai-PJ, podendo produzir uma orientação para o sujeito que se encontra acossado por intensa angústia e sofrimento.

Um fragmento de caso; A oferta de acompanhamento pelo Pai-PJ, faz com que João vire frequentemente para a técnica de referência do programa para contar que teve a sua pele roubada, essa é uma queixa constante desse paciente que se manteve em sofrimento corporal, o tempo todo falando que estava sem costela, minha pele foi roubada, cadê a pele do Rambo assim, muito delirante com essa questão e muito angustiado, com passagens ao muito grave, então ele passa a ligar para o programa e isso se torna um recurso, ele vai lá conversar, se queixar, pedindo para que a justiça tome providências. Isso produz para esse sujeito um certo apaziguamento.

Para Carlos, outro paciente acompanhado pelo programa, levar relatórios que comprovam seu tratamento para anexar ao processo em função decisiva, ele faz questão de levar, porque ele quer mostrar para o juiz como que ele tá cumprindo a sentença que ele recebeu, e o juiz passa então a fazer parte dessa rede para esse sujeito. Luiz encontrava-se em situação de crise, tendo passado por várias internações, é um caso que, desde de lá do começo Pai-PJ, anteriormente a ascensão do programa, ele tinha esse histórico de várias internações, e ele estabiliza quando alguém testemunha diante do juiz, que ele era um bom rapaz, ele merecia uma chance porque ele era um bom rapaz, então nessa ocasião ele deixa o tráfico de drogas, ele se nomeava de matador, ele falava que tinha matado sete pessoas, era um traficante considerado perigoso e tudo, então ele deixa de usar drogas, deixa o tráfico, e vai então começar a cuidar das pessoas da sua família que precisavam de cuidados, que fazem tratamentos de saúde etc, e ele estabiliza a partir dessa ocasião, desse testemunho diante do juiz, isso passa a valer para ele como uma orientação. Bom, tem vários casos, acho que eu vou parar por aqui, eu vou só falar um pouco para vocês de alguns resultados, hoje nós temos 1700 casos mapeados em Minas Gerais, a gente não está no momento atendendo todo o estado de Minas Gerais por um 
problema da gestão anterior do Tribunal de Justiça, mas a atual gestão está reestruturando o programa, nós não sabemos ainda quando que vai ser possível voltar ao interior do estado, no momento a gente está na região da grande Belo Horizonte, mas nós temos então mapeados 1700 casos, 6000 casos já passaram pelo programa, o tempo médio de permanência é de cinco anos, e a reincidência dois por cento. Tem aí o contato, tem o site do Tribunal de Justiça, tem o site da Revista Responsabilidades quem desejar dá uma olhada tem vários artigos, têm uma monografia que foi premiada da Fernanda Otoni, está inteiramente disponível lá na página da revista, todos os números estão integralmente disponíveis on line, quem desejar dá uma olhada.

Então é isso gente, muito obrigada.

\section{A experiência italiana do fechamento de hospitais psiquiátricos judiciais - $\mathrm{Dr}^{\mathrm{a}}$ Giovanna del Giudice}

Médica, Psiquiatra, Presidente da Conferenza Permanente per la Salute Mentale nel mondo Franco Baságlia - Trieste/Itália.

Boa tarde a todos.

Primeiro, eu gostaria de fazer alguns agradecimentos e saudações. Em particular, inicialmente, a Sônia Barros que permitiu que eu pudesse participar desses dias, que são dias de encontro, de grande valor, de muito interesse seguido por nós, da Itália, que acompanhamos os processos de desinstituicionalização que aqui aconteceram e continuam a acontecer. Quero agradecer a generosidade da Fernanda que me acompanha na tradução nesses dias. E gostaria também de trazer a saudação de Franco Rotelli, assim como dos colegas e amigos do Departamento de Saúde Mental de Trieste a todos os companheiros e companheiras do Movimento Antimanicomial do Brasil, com o qual nós nos ligamos com tantas pessoas com uma grande amizade.

Eu vou buscar trazer para vocês, de forma sintética, e em certo sentido breve, o processo que está sendo desenvolvido na Itália, principalmente, nos últimos cinco anos e que resultou no fechamento dos hospitais psiquiátricos judiciários. Processo certamente complexo, repleto de obstáculos e dificuldades que, evidentemente, não se conclui com o fechamento dos hospitais psiquiátricos, mas que talvez possamos dizer que ele tem um próprio desenvolvimento a partir do fechamento dos hospitais psiquiátricos judiciários. 
Para dizer para vocês de onde nós partimos. Na Itália, em dezembro de dois mil e onze, existiam seis hospitais psiquiátricos, um dos quais somente para mulheres. Nesses seis hospitais psiquiátricos judiciários estavam internadas mil e quatrocentas pessoas, em dois mil e seis, para contextualizar, a Itália tem sessenta milhões de pessoas, um país que fechou os hospitais psiquiátricos públicos e gerais, gerais no sentido de não serem os judiciários, em mil novecentos e setenta enove.

Eu não farei referências às normativas e à cultura científica que fundem, legitimam os hospitais psiquiátricos judiciários, na medida em que a relatora precedente abordou as normas que fundam os hospitais psiquiátricos judiciários e que podemos perceber a absoluta semelhança entre essas normas e essas culturas na Itália e no Brasil. Podemos sintetizar essas normas na Itália que estão no Código Penal, o Código Penal Italiano, o Código fascista de mil novecentos e trinta, uma pessoa então que cometeu um delito ou um crime é declarada incapaz e lá eles têm essa expressão de "incapaz de compreende e de querer" e ela passa e é tida também como perigosa socialmente, ela vai então ser encaminhada ao hospital psiquiátrico judiciário após ter sido isenta em termos de processo criminal e ela passa pelo percurso totalmente especial em relação às outras pessoas que cometem atos ou delitos em conflito com a lei. Isso significa então que na base da internação do hospital psiquiátrico judiciário tem um duplo trilho, são dois trilhos e ela passa ter um estatuto especial.

Por que eu enfatizo isso como uma questão central? Porque quando a lei cento e oitenta, promulgada em setenta e oito, na Itália, que coloca fim ao estatuto especial do louco e coloca como sujeito, pleno da cidadania social e entra para a cidadania social, desculpe, evidentemente, isso coloca uma evidente contradição com o Código louco. É evidente que após a prorrogação da lei cento e oitenta da Itália nasce um conjunto de propostas feitas por juristas e também por psiquiatras que denunciam a inconstitucionalidade dos hospitais psiquiátricos judiciários e evidenciam a contradição colocada com a prorrogação da lei cento e oitenta.

A Corte Constitucional, daquele período, foi estabelecendo um conjunto de sentenças que fragilizam, mas que de alguma forma não resolvem a questão. Em particular, uma sentença que é publicada logo depois da promulgação da lei cento e oitenta, coloca em discussão e busca superar, colocar um fim nessa conexão entre presunção de periculosidade e doença mental. Portanto, uma pessoa que cometeu um delito e ela foi isenta, ela não pode ser simplesmente encaminhada automaticamente para o hospital psiquiátrico judiciário, a não ser que a sentença aplicada a coloque como perigosa. Ou seja, não tem mais esse nexo automático com a periculosidade da pes- 
soa com transtorno mental. Depois dos anos dois mil, duas importantes sentenças da Corte Constitucional.

A primeira, que reitera que com a promulgação da lei cento e oitenta e da constituição de uma rede de serviços comunitários, declara a ilegitimidade do hospital psiquiátrico judiciário, porque significa produzir uma discriminação na medida em que as pessoas deveriam, pela lei cento e oitenta, serem cuidadas nos serviços do território. Sanciona que, o direito à saúde deveria ser superior, deveria superar o direito de tutela da comunidade. E, portanto, ela coloca que, pessoas com transtornos mentais, que cometeram algum tipo de delito, deveriam ser aplicadas medidas alternativas, que as possibilitassem de serem cuidadas nos serviços da comunidade. Isso permite a alguns departamentos de saúde mental italianos não recorrer mais ao hospital psiquiátrico judiciário, exatamente aplicando essa sentença da Corte Constitucional e trabalhando com a magistratura local, ou seja, isso permite que mesmo com o veto do Código Civil, possa se buscar alternativas que não fosse o encaminhamento a um hospital psiquiátrico judiciário. E assim, do que eu tenho conhecimento tanto em Trieste quanto a Áquila, desde os anos dois mil não se interna mais nenhuma pessoa no hospital psiquiátrico judiciário mesmo na presença do Código, na aplicação da sentença da CorteConstitucional.

O processo de fechamento dos hospitais psiquiátricos judiciários, ele passa a ser desenvolvido a partir de dois mil e oito, quando uma comissão contra a tortura e os tratamentos desumanos e degradantes do conselho da Europa visitam um hospital psiquiátrico judiciário italiano e denuncia ao governo italiano, o estado de atraso e de violação dos direitos humanos das pessoas ali encontradas. A partir então, desse Conselho europeu, o Senado italiano constituiu uma comissão de inquérito, que possibilita intervenção e realização de visitas de inspeção não agendadas em todos os hospitais psiquiátricos judiciários a partir de julho de dois mil e dez. Os senadores então verificam as condições desumanas, degradantes nas quais as pessoas vivem, ou melhor, são constrangidas a viver nos seis hospitais psiquiátricos judiciários e denunciam a situação de degradação, de abandono e de tortura presente nesses lugares. Em particular, é colocada bastante luz, bastante visibilidade à prisão perpétua branca, ou seja, pessoas internadas por trinta, quarenta, cinquenta anos em hospitais psiquiátricos judiciários, pelos mecanismos já aqui apresentados anteriormente, pessoas que cometeram delitos muito pequenos, como por exemplo: furto de uma bicicleta, furto de alguma outra coisa; como aqui temos nessa situação e que passam então a ficar internadas por toda sua vida. Essas visitas de inspeção então da comissão de inquérito produz um vídeo que foi apresentado no Parlamento italiano, que coloca para os senadores a necessidade que 
eles pudessem conhecer as instituições, instituições em relação às quais eles não tinham assumido responsabilidade nem em relação a essas instituições nem em relação à trajetória dessas pessoas. Esse mesmo vídeo foi projetado no circuito de televisão comum, isso significa que não é possível que nenhum italiano diga que não conhece ou que não sabe sobre o horror que são os hospitais psiquiátricos judiciários. Assim, se coloca em movimento um processo legislativo e em fevereiro de dois mil e doze é promulgada uma lei que fixa o prazo de um ano, dois mil e treze, para o fechamento dos hospitais psiquiátricos judiciários. Essa mesma lei coloca que, em cada região italiana, devam ser criadas residências sanitárias onde as pessoas estarão internadas no desenvolvimento, enquanto elas cumprem a medida de segurança, as pessoas que estavam internadas nos antigos hospitais psiquiátricos; assim como aquelas que foram consideradas isentas. Também está previsto por essa lei, a constituição de um orçamento para a construção ou a transformação para a criação dessas residências sanitárias. Nesse mesmo momento, se desenvolve um forte movimento contra essalei.

Um conjunto de associações, dentre elas a Conferência Permanente para a Saúde Mental no Mundo Franco Basaglia, o Sindicato Nacional dos Trabalhadores, o Fórum de Saúde Mental, associações que defendem os direitos dos presos, a partir de uma coordenação comum começam a colocar críticas a essa lei. Essa coordenação comum passa a ser denominada Stop ou Stop HPJ, ou seja, os hospitais psiquiátricos judiciários Stop e faz forte crítica a esta lei no sentido de colocar que o fechamento dos hospitais psiquiátricos judiciários, nessa perspectiva, poderia reconstituir em cada região italiana, nessas residências, novos pequenos hospitais psiquiátricos sem, exatamente, uma transformação dalógica.

Esse conjunto de associações da qual eu faço parte, passa a exercer uma vigilância constante desses processos, desencadeados a partir de dois mil e doze, numa perspectiva de reduzir danos, de tentar buscar melhoras importantes na lei, assim como nas culturas que a sustenta. Esse conjunto de associações torna- se, então, um interlocutor fundamental neste diálogo com o Senado e com a comissão do Senado. No meu ponto de vista, nesse diálogo, esse conjunto de associações pode determinar uma melhora significativa da lei nos anos que se seguiram. O que quero dizer com isso? Nesse processo, se buscou que a ênfase não fosse que a alternativa ao hospital psiquiátrico judiciário fosse colocada nas residências sanitárias, para o lugar por excelência, para a execução para o desenvolvimento das medidas de segurança e passasse a uma ênfase nos percursos terapêuticos reabilitativos, individuais, usando, inclusive as sentenças da Corte Constitucional que eu assinalei precedentemente para se buscar medidas alternativas à detenção. Isso significa, 
portanto, que mais uma vez nós colocamos o foco porque essa passagem deve se dar, não centrada nas instituições, mesmo sendo elas pequenas, mas o foco deve ser o cuidado em liberdade e no território. Como é o momento atual? Ocorreram duas prorrogações do prazo em relação ao fechamento dos hospitais psiquiátricos judiciários e foi definido então um novo prazo de março de dois mil e quinze. Essas prorrogações foram reveladas como necessárias, na perspectiva de efetivamente, é aquela expressão que nós conhecemos de difícil tradução literal: "assumir o encargo", que nós traduzimos para "assumir a responsabilidade pelas mil e quatrocentas pessoas que estavam presentes em dois mil e onze, nos seis hospitais psiquiátricos judiciários".

E isso, através então, dessa possibilidade de assumir a responsabilidade dos serviços de saúde mental e naquelas situações onde não era possível que houvesse então a transferência para essas unidades. E onde estamos hoje? Os dados que apresento são de seis de novembro de dois mil e dezesseis. Foram fechados quatro hospitais psiquiátricos judiciários. Então, isso significa que permanecessem dois hospitais psiquiátricos judiciários abertos, mas para um total de vinte e seis pessoas. Nas regiões italianas foram construídas vinte e seis residências sanitárias, os lugares então para o desenvolvimento da medida de segurança. Com total de seiscentos e dois leitos nas residências, não propriamente leitos, lugares. Foram acompanhadas até agosto setecentas pessoas, mas tiveram alta, aproximadamente quinhentas. Isso significa que teve uma importante melhora no sentido que os dados indicam que diversas das pessoas internadas nos hospitais psiquiátricos judiciários foram assumidas pelos departamentos de saúde mental, mas depois com o processo de transinstitucionalização. E assim, com a melhora da lei, com as leis que prorrogaram os prazos, com investimento desse comitê Stop HPJ, podemos dizer que temos certa superação da prisão perpétua branca, com transformações importantes, porque nenhuma pessoa pode ser mais internada no hospital psiquiátrico judiciário ou em uma das residências, senão pelo mesmo período que outra pessoa que não tenha transtorno mental da pena que ela cumpre.

Outro dado importante é que essas estruturas regionais das residências são heterogêneas, elas apresentam diversas diferenças em termos de organização e funcionamento. Isso significa, esta heterogeneidade, essa diferença, que não tem exatamente uma regulamentação, mas que também coloca a possibilidade de que essas residências possam ser superadas. De alguma forma, o momento atual é de Stop Residências Sanitárias, para que seja efetivamente assumida a responsabilidade das pessoas que cometerem conflito com a lei, pelos departamentos de saúde mental. E isso significa que nos próximos dias, talvez agora já em dezembro, vai fechar mais um hospital psiquiátrico judiciário, perma- 
necendo apenas um, mas apenas com dez pessoas e isso significa que daqui alguns meses nós poderemos dizer que, na Itália, não haverá mais essa instituição total aberrante que é hospital psiquiátrico judiciário. E isto me parece muito importante, mas evidentemente, devemos continuar a investir para a superação desse trilho duplo, ou seja, desse estatuto especial para pessoas com transtornos mentais em conflito com a lei. Isso significa que reinstituir o direito à responsabilidade, o direito que essas pessoas possam vivenciar o processo. Devemos colocar em crise até a superação, as normas de periculosidade social. Nós sabemos que esse é um processo longo e difícil, mas nós sabemos que a desinstitucionalização é contínua e, portanto, mesmo quando nós superamos ou fechamos as instituições, nós devemos continuar a colocar em discussão e superar as normas e a cultura que a sustenta. Uma última questão, eu estou participando, fazendo uma visita na qualidade de participante do comitê Stop HPJ em todas essas residências sanitárias. O que me parece mais importante nessas visitas é verificar que os operadores que estão nessas residências, que foram ao encontro dessas pessoas que cometeram delitos, eles estão claramente colocando que não é necessário, estruturas especiais, dedicadas a essas pessoas, porque elas são como todas as outras pessoas, que estão presentes também nos centros de saúde mental e aquilo que é necessário é o cuidado em liberdade, é a garantia do direito à atenção e não à segregação.

\section{Programa de atenção integral ao louco infrator (PAILI) - Dr. Haroldo Caetano da Silva}

Promotor de Justiça do Ministério Público do Estado de Goiás, Premiado pelo Instituto Innovare, em 2009, como vencedor do VI Prêmio Innovare, na categoria Ministério Público, com o Programa de Atenção Integral ao Louco Infrator (PAILI).

Boa tarde, gente.

Eu acredito que a responsabilidade é muita, eu vou falar por último. A responsabilidade é grande por falar por último, mas não é uma coincidência. Porque de imediato eu já digo para vocês algo que talvez possa parecer um tanto quanto ousado.

Mas o fato é que Goiás alcançou em 2006 aquilo que a Itália ainda não alcançou. Goiás alcançou em 2006 erradicação do manicômio judiciário. Quem está falando aqui é promotor de justiça, mas é um promotor de justiça que há vinte anos, na verdade a vinte 
e um, está atuando na execução penal. Então, deixa eu só situar para aqueles que não me conhece. Em 95 eu assumi uma promotoria em Goiânia, na execução penal, e comecei a lidar com essa matéria logo de início, em outubro de 2005. Até que rapidamente, já em março, 96 aconteceu um fato, um fato que é muito marcante e eu faço questão de registrá-lo aqui.

É que em março de 2006, quem é mais velho vai se lembrar, houve uma grande rebelião na maior penitenciária do estado de Goiás, o CEPAE. E, naquela ocasião, foram feitos muitos reféns, autoridades públicas, juízes, até o secretário de segurança pública estava entre os reféns, o presidente do Tribunal de Justiça estava entre os reféns e este promotor que vos fala também. Fiquei uma semana dentro da cadeia como refém numa rebelião, assim, muito complicada como qualquer rebelião costuma ser, não é? Naquela ocasião eu me deparei com a população carcerária e lá dentro, também funcionava um manicômio judiciário.

Os pacientes em medida de segurança estavam, também, dentro da maior penitenciária do estado de Goiás. E desde então, é que a gente vem trabalhando esse tema. Em 96 aconteceu esse fato, o PAINI, o Programa de Atenção Integral ao Núcleo Infrator vai nascer dez anos depois em 2006. Estou abreviando bastante a história, evidentemente. Essa rebelião tem, como eu sobrei para contar a história, ela tem muitas boas histórias também, mas vai ficar para uma outra ocasião para a gente falar um pouco disso. Primeiro é importante frisar uma coisa, nós estamos falando aqui é de uma coisa, porque o manicômio nos é apresentado como uma coisa dada, como algo natural, não é? Como se fosse algo de fato essencial para a existência, para a coexistência social. Quando, de fato, ele não passa de um instrumento de controle, não é? Dentro de uma política nefasta de gestão da miséria, para a qual sobra normalmente esses dispositivos que estão aí na tela.

Aliás, faço um registro por importante que a desumanização do delinquente, seja ele quem for, inclusive o louco, ela já começa no ato da detenção pela polícia, o sujeito é colocado dentro do porta- malas de uma viatura policial e isso é visto também como uma coisa absolutamente normal, pela nossa sociedade. E nós acabamos por reproduzir e reforçar esse conceito, esse conteúdo que representa de fato a desumanização, não é? Você retira a condição de pessoa e a partir desse momento, dela lhe são tirados direitos como nós vemos acontecer dentro do presídio, dentro do manicômio, dentro dos diversos dispositivos de instituições de controle.

Nesse espaço qual é o lugar do louco? Dentro da sociedade capitalista, fora das relações produção e consumo, qual é o lugar da miséria? Qual é o lugar do louco? 
Então é disso que nós estamos falando. Nós precisamos nos localizar porque trata-se de fato de um dispositivo, o manicômio judiciário, um dispositivo de gestão da miséria. Quem conhece o manicômio judiciário vai perceber rapidamente lá dentro que são todos pobres, eu conheci muitos manicômios pelo Brasil. E de fato jamais encontrei alguém em boa condição socioeconômica que estivesse internado, internado é eufemismo, não é? Que estivesse preso em manicômio judiciário. Mas essa figura vem daquilo que já foi falado nas outras mesas, dessa disputa de uma legislação de 1940 com a legislação de 2001, que é a lei antimanicomial.

Estou falando rápido porque eu quero falar, passar todo o conteúdo, quero tentar ser o mais claro possível, mas sem perder o conteúdo daquilo que me propus a dizer aqui para vocês.

Ultimamente, no Brasil nós temos por banalizada a expressão fascista. Por conta da divisão da sociedade nessa disputa, enfim, que nos coloca em lados opostos, às vezes até dentro de casa com os nossos irmãos, com os nossos amigos, não é? Quem não tem tio 'reaça' por aqui ou quem, quem é ou é 'reaça' e não tem um tio 'petralha'. Então isso é um fato, não é? Mas se tem algo que você pode, a professora Giovanna não me deixa mentir, pelo que ela já disse agora há pouco, se tem algo que é essencialmente fascista, eminentemente fascista e está lá na legislação brasileira é a medida de segurança. A medida de segurança não tenho medo de dizer, é um dispositivo fascista, ele vem para o Brasil inspirado, como a professora Giovanna deixou claro na fala dela também, no Código Roco, no código fascista italiano, e em 1940 nós copiamos essa disposição. Até então a pessoa que era considerada inimputável, ou seja, sem responsabilidade penal, era simplesmente absolvida, mesmo que fosse louca, não ia para manicômio judiciário. Havia outros dispositivos, é verdade, mas do ponto de vista jurídico penal ela não era submetida a essa estrutura, a essa instituição total do manicômio. Que se baseia, como já foi falado muitas vezes aqui, não vou repetir, na periculosidade de pretensão. Na pretensa periculosidade do louco, não é? Que aliás, periculosidade era algo que tinha um alcance muito maior daquilo que a gente poderia imaginar.

Hoje, olhando com olhar de 2016 para 1940 vocês vão ver hoje um certo ridículo no conteúdo da norma. Porque em 1940, com a legislação de então, era perigoso até o sujeito que viesse a ser condenado, digamos, por dois crimes de furto. A reincidência, por si só, implicava naquele sujeito a condição de perigoso. E, além da pena, ele era submetido também à medida de segurança. Isso mudou em 1984, com a reforma penal, nós deixamos o duplo binário e passamos assumir no Brasil o que o direito penal estabelece como sistema diferente. Onde somente se aplica pena ou medida de segurança, não as 
duas coisas ao mesmo tempo. De forma então, que o sujeito que é responsável, digamos aquele ladrão do furto que mencionei, ele vai ser submetido a uma sanção penal e vai para a prisão. Ao passo que o louco não, ele não é submetido à prisão, mas é submetido apenas a medida de segurança. Então separou-se, em 1984, essa questão. Entretendo, aí é importante mencionar também que lá em 84, diferentemente de 40; lá em 1940 a medida de segurança era essencialmente uma sanção, uma punição do louco. Era vista como algo de natureza sancionatória, punitiva, a medida de segurança aplicável ao louco. Em 84, pelo menos do ponto de vista da norma, o código penal passou a falar em tratamento, no artigo 98 do código penal.

A medida de segurança então devia ser, não mais uma sanção, mas era tratamento. Ocorre que o mesmo código penal, aliás, só para não ficar sem explicação, eu coloquei algumas ilustrações, mas são meras ilustrações mesmo, não tem às vezes relação direta com o conteúdo do slide. Aí nesse caso até nessa foto está de cabeça para baixo, foi uma visita que eu fiz lá no manicômio judiciário de Franco da Rocha, aqui pertinho. Vocês podem observar que eu estava com esse mesmo paletó que é o único paletó que resiste ao frio de São Paulo, para vocês verem que está sempre guardadinho. (Eu venho com alguma frequência a São Paulo.) Mas o código penal ainda definido como tratamento, ainda assim estabelecia que a medida de segurança seria aplicada não segundo a necessidade clínica, a internação ou o tratamento ambulatorial seriam utilizados não pela necessidade clínica, mas sim pela natureza do crime, a natureza da pena culminada ao crime. Se o crime era punível com reclusão, internação do sujeito.

Acontece que no Brasil quase tudo é punível com reclusão, até uma tentativa de furto de uma geladeira, o louco tenta carregar uma geladeira de um supermercado, vai ser preso, evidentemente. Nesse caso ele vai ser submetido a uma internação não porque ele precisa, do ponto de vista terapêutico, de uma internação, mas porque a norma define que o crime de furto é punível com reclusão. Então, a regra geral passa a ser a internação para todo mundo, e a medida de segurança ficava então vinculada a uma sensação de periculosidade, disso que nós já falamos, desse conceito absurdo. Vou falar um pouco mais sobre ele daqui a pouquinho também.

E o paciente vai para o HCTP, que é o hospital psiquiátrico judiciário da Itália e que aqui é o nosso manicômio judiciário. HCTP é um nome bonitinho, é uma sigla para o nome bonitinho de Hospital de Custódia e Tratamento Psiquiátrico, que é um belo de um eufemismo para prisão do louco. Essas fotos eu fiz questão de colocar, porque eu fiquei muito impressionado quando eu visitei esses lugares. Essa, deixa eu ver se aqui tem aquela luzinha, essa foto maior, a resolução não está boa, é um manicômio aqui de São 
Paulo que fica lá na cidade de Casa Branca. Esse corredor que atravessa os pavilhões tem 700 metros de cumprimento, para vocês terem uma noção do tamanho que é aquiloali.

No passado era outra coisa, era utilizado para outro público, mas hoje é um manicômio judiciário. O outro manicômio eu coloquei mais pela curiosidade, porque ele é o complexo médico penal de Curitiba. Vejam que ele, a estrutura original dele é essa estrutura central que tem formato de um fuzil.

A arquitetura projetou um manicômio judiciário no formato de um fuzil, bem apropriado, evidentemente. Mas o HCTP o quê que ele é? Ele é aquilo, no que couber, equivalente a uma cela. E o quê que é uma cela? É um lugar onde se colocam, onde as pessoas que são condenadas são presas, não é? E assim como o condenado, o paciente em medida de segurança lá no manicômio judiciário, no HCTP, é colocado também nessa estrutura celular que nós sabemos muito bem que os presídios, os manicômios são presídios apenas com outro nome, e que recebem os mesmos, têm praticamente as mesmas características. Aliás, são até instituições que normalmente são cuidadas ou geridas, melhor dizendo, cuidadas nunca são, são gerenciadas pela administração penitenciária dos estados.

Acontece que em 1988 veio a Constituição e estabeleceu textualmente o direito penal da culpabilidade. O quê que é isso, de onde isso vem? Um dispositivo da Constituição que diz que nenhuma pena passará da pessoa do condenado. O quê que isso quer dizer em outras palavras? Que para que alguém seja submetido a uma sanção penal, a um dispositivo punitivo, castigo, portanto, ele precisa ser declarado culpado, ele tem que ser condenado na sentença penal. E essa condenação pressupõe culpabilidade, e o louco não é culpável, justamente por conta da não responsabilidade penal que o código penal define. Ele é imputável porque não conhece o caráter ilícito do fato ou não consegue se determinar de acordo com esse entendimento. Não tem responsabilidade penal, se não tem responsabilidade penal ele não tem culpa, se ele não tem culpa, ele não pode ser condenado, se ele não é condenado ele não pode ser submetido a uma sanção penal.

A sanção penal por manicômio, então, foi retirada pela Constituição de 88. Não mais persiste a natureza sancionatória da medida de segurança, aquela lá do código fascista de 1940. Nenhuma pena passará para a pessoa do condenado. Isso significa que para alguém ser preso no Brasil ele precisa ser submetido a um processo, precisa ser condenado nesse processo. E o louco, quando ele é submetido a um processo ele é absolvido no processo. Ah, mas ele praticou um homicídio grave, um estupro, um latrocínio, um crime cruel, não interessa. Do ponto de vista jurídico penal ele é inocente, se o sujeito é inocente ele é absolvido. Ah, mas ele é perigoso, aí é uma outra questão que nós vamos discutir um pouquinho. 
A Lei de 2001 todo mundo aqui já leu, com certeza, mais de uma vez, mas ela vem e passa a não deixar nenhuma dúvida quanto ao tratamento que deve ser dispensado a qualquer pessoa com transtorno mental. Qualquer pessoa com transtorno mental submetida a qualquer tipo de tratamento psiquiátrico deverá receber o tratamento regulado na Lei 10.216, que se funda na liberdade do sujeito, não é? E eu destaco esses dispositivos porque eles, a gente precisa registrar esses dispositivos e nos assenhorar desses dispositivos para aplicá-los também nos manicômios judiciários que eles estão funcionando no Brasil, e não são poucos.

O Censo de 2011, feito pela Débora Diniz por encomenda do Ministério da Justiça, registrou quase 4 mil pessoas internadas em manicômios naquela ocasião. A internação, em qualquer de suas modalidades, só será indicada quando os recursos extra hospitalares se mostrarem insuficientes. Então de cara você já tem aí uma norma que modificou o código penal. Então, o sujeito lá do código penal que praticou o crime ele não vai ser levado a uma internação psiquiátrica porque praticou um crime de furto ou porque praticou um crime de homicídio ou porque um estupro, isso é indiferente. O que vai determinar o tratamento pelo regime de internação é o quê? A necessidade clínica, a necessidade terapêutica para esse paciente. Quem vai dizer isso? A equipe de saúde, não é? Que atende, que acompanha esse sujeito. Até porque, e é bom fazer esse registro, digamos num crime de homicídio, o homicídio aconteceu há um ano e meio atrás num momento em que o sujeito estava em crise, em surto psicótico. Naquele momento talvez ele precisasse de uma internação, provavelmente sim. Hoje, passados um ano e meio, ele precisa de internação? Muito provavelmente não, mas se ele precisar isso poderá ser utilizado, mas a realidade, a necessidade clínica deste ou daquele recurso terapêutico é identificada agora. E não vai ser uma sentença, que dista tanto tempo assim do fato, que vai determinar o melhor tratamento. $O$ tratamento visará como finalidade permanente a reinserção social do paciente em seu meio. Se tem algo que rompe com qualquer laço social é uma internação, e uma internação manicomial rompe quase que definitivamente os laços familiares e sociais.

Não é só na Itália que tem paciente com 40 anos em medida de segurança, aqui também temos gente nessa mesma condição, internada em diversos manicômios pelo país. Então o manicômio vai contra esse dispositivo. Diferentemente da internação manicomial, nós temos que usar outros dispositivos que busquem esse objetivo que é obrigatório, esse é um objetivo fundamental no atendimento à saúde mental. Mas, tão importante quanto isso é o parágrafo $3^{\circ}$, que para qualquer entendedor, não precisa ser jurista, é claro, é de uma clareza solar que quase nos cega. "É vedada a internação 
de pacientes portadores de transtornos mentais em instituições com características asilares".

Quer algo mais claro do que isso? A internação asilar está proibida no Brasil desde 2001, 15 anos. Há 15 anos a porta de entrada do manicômio judiciário está fechada, do ponto de vista da norma. Não dos aplicadores da norma, mas do ponto de vista da Lei, quer algo mais claro do que essa disposição? E o quê que tem característica asilar por excelência nesse espaço que seja mais asilar do que um manicômio judiciário? Como já foi dito aqui, o professor já no início falou, que é aquilo que é o limite do limite onde a lei ainda não teria chegado, evidentemente aonde funciona o manicômio judiciário, não é o caso do meu Estado. Mas é o que acontece aqui em São Paulo e em praticamente todo o país.

Mesmo em Minas Gerais, que tem brilhante programa, que é precursor ao nosso, inclusive, mesmo com todo o esforço e empenho dos profissionais do PAEPJ e a dedicação e a qualidade dos serviços são que oferecidos pelo PAEPJ, muito bem apresentado aqui pela Professora Romena, Minas tem uma tradição manicomial pesada, são três manicômios judiciais em plano funcionamento em Barbacena, em Juiz de Fora e em Ribeirão das Neves. O que me permite dizer então? É que Juiz de Fora está sendo fechado. Eu quero ver a notícia dele estar fechado, ainda. Mas o que se tem então é que há uma ilha antimanicomial, num mar de manicômios que é o país inteiro, manicômios judiciais. $\mathrm{E}$ nós precisamos de fato enfrentar essa questão, é para isso que estamos tentando dialogar, aquitambém.

Ambiente manicomial prevê uma série de dispositivos e direitos da pessoa com transtorno mental e eu registro aí ressalva de alguns deles. Primeiro para dizer que a internação, em qualquer das suas modalidades, será sempre um dispositivo de saúde. Então, se aquele sujeito está incomodando na rua o vizinho, isso não é problema de saúde, isso é um problema de convivência entre os sujeitos. Se, o sujeito está, enfim, não é um dispositivo de segurança pública. Internação é um dispositivo de saúde. Deixa eu voltar nessa imagem porque não tem como não falar, o que de mais lindo aconteceu nos últimos quinze anos, não é?

No campo da reforma psiquiátrica foi produzido pelos usuários, pelos usuários não, pelas vítimas do manicômio judiciário de Franco da Rocha. O que de mais belo aconteceu aí foi agora, há um pouco mais de um mês. Em que os pacientes do manicômio judiciário de Franco da Rocha fugiram, não é? Na cela foi a imagem com pouca resolução, mas tem gente lá no, fugido lá em cima do morro escapando do manicômio de Franco da Rocha e lá embaixo o manicômio destruído. O manicômio é algo tão 
ruim, mas tão ruim, nós não sabemos disso, mas os loucos sabem tão bem disso que eles não querem o manicômio não é para eles não, não querem para ninguém, fogem e põe fogo no que ficou. E a internação psiquiátrica, vão dizer: "Ah, mas essa lei não se aplica”, aplica sim. Lá no artigo $6^{\circ}$, parágrafo único, inciso $3^{\circ}$, a lei se aplica a qualquer tipo de internação, inclusive a compulsória, que é a determinada pela justiça. É a única internação compulsória que existe na nossa legislação é feita em medida de segurança. E ainda assim deve obedecer aos dispositivos da lei 10.216. Tem que ser excepcional, tem que ter objetivo de reclusão social, tem que ser, enfim, obedecer a todos aqueles recursos que são definidos no artigo $2^{\circ}$ como direitos da pessoa com transtorno mental, dentre um milhão de outras questões que eu não vou poderfalar agora. Enfim, o manicômio tornou-se uma instituição ilegal, e essa foto eu recebi na semana passada em um evento do qual participei em Curitiba. Alguém aqui, estava naquele evento? Não? Mas na semana passada eu estive num evento sobre saúde, desintitucionalização em Curitiba, essa foto que me foi trazida por uma juíza. E essa pessoa se chama, é uma mulher se chama Marisa, está há 23 anos, não está há 23 anos internada, ela está no manicômio judiciário de Curitiba há 23 anos com ordem de soltura. Há 23 anos ela recebeu ordem de liberação do manicômio judiciário. Mesmo com ordem judicial de liberação do manicômio judiciário, há 23 anos ela continua lá. Isso vai nos levar a uma outra questão que eu quero falar rapidamente aqui, porque eu estou pressionado pelo tempo. Mas vamos voltar nela daqui a pouquinho. Isso significa então, que a legislação, e eu estou falando de tudo isso aqui, eu estou falando, ao falar de tudo isso aqui eu estou falando do Programa de Atenção Integral ao Louco Infrator. É com base nessa perspectiva toda é que nós instituímos lá essa figura antimanicomial por excelência que aboliu a possibilidade da internação asilar, da internação em manicômio judicial fundamentalmente. A porta de entrada está fechada em 2001, do ponto de vista da norma, o PAI é o primeiro a fechar efetivamente isso em 2006, foram cinco anos depois. A porta de saída está aberta, mas não é para sair de qualquerjeito.

Há quinze anos ela deveria estar sendo trabalhada, visando a obra planejada e a reabilitação psicossocial assistida. Está lá no artigo $5^{\circ}$ da Lei antimanicomial. Um pouco, esse slide anterior falava desse conceito jurídico da periculosidade, não é? Que a medicina trouxe para si e criou a figura do louco perigoso que não observa nem princípios fundamentais do direito penal nem princípios fundamentais da medicina. Louca, na verdade, é a figura da periculosidade que ali foi estabelecida. Mas eu não vou ficar, não vou me ater a isso. Não se fala mais em periculosidade, qualquer tratamento em saúde mental visa a reinserção, não há outro objetivo a ser alcançado no tratamento em saúde mental. Mesmo para aqueles, mesmo que praticou um crime grave. 
O tema sai da esfera da segurança pública, passa a ser trabalhado na esfera da saúde pública. O PAILI em Goiás é um programa que funciona, não é lá do Ministério Público, não é do Poder Judiciário, é um programa da Secretaria de Estado da Saúde. Vou falar um pouquinho da estrutura dele rapidamente daqui a pouco. Eu coloquei a ilustração, eu coloquei o Belchior e o Raul Seixas aí porque são poetas, não é, que levam para a poesia essa inquietação diante da loucura. Para ficar só um registro rápido aqui: "A minha alucinação é suportar o dia a dia, e o meu delírio é a experiência com coisas reais" Belchior, não é? E eu gosto muito de meu amigo, meu amigo Pedro, do Raul Seixas. E ele conversa com Pedro, não é, autoral: “Cada um de nós é um universo (............) deixa eu viver a minha loucura”. Enfim, são poetas quetrazem essa coisa mais sensível para a questão da loucura. Tudo isso aí dá fundamento ao PAILI, o Programa de Atenção Integral ao Louco Infrator que funciona em Goiás e nos rendeu o prêmio INOVARE como já foi falado aqui, lá em 2009.

Aqui são algumas reuniões que foram feitas lá.

Como funciona isso aí? Vou tentar ser breve... Rotina: como é que funciona isso? Bom, lá não tem manicômio, como é que as pessoas são encaminhadas nesses, a partir do momento que são submetidas à uma medida de segurança? A sentença aplicou medida de segurança, o caso é estudado pelo PAILI que vai indicar qual será o melhor dispositivo de saúde a ser utilizado naquele caso, a internação será sempre excepcional. Nós veremos daqui a pouco nos dados estatísticos. Então a tarefa ambulatorial tem sido a regra, e o paciente vai para o tratamento ambulatorial. Eventualmente o PAILI vai buscar o paciente dentro da casa de prisão provisória, ele está preso provisoriamente. Sai a sentença, o PAILI busca o paciente lá e vai fazer o estudo e inseri-lo no melhor dispositivo da rede. Nós não falamos em periculosidade, falamos em avaliação psicossocial. Eu não quero saber se o sujeito é perigoso, essa coisa estranha que não tem fundamento algum, a não ser do mito. Eu quero saber se ele trabalha, se ele tem filho, se ele tem família, se ele tem condições de se manter, enfim, até para se conhecer a sua realidade psicossocial para saber também qual é a necessidade que ele vai precisar, o apoio que ele vai precisar para se tratar, para ser acompanhado. Aí isso acontece até que ele venha ter a liberação condicional, que é normalmente depois de um ano, e a medida de segurança é extinta. Isso tudo funciona, eventualmente o paciente que está em medida de segurança lá em Goiás passa por um surto psicótico, aliás, como qualquer pessoa que é atendido na rede de saúde mental eventualmente vai passar, pode passar. O que fazer nesse caso? Ele vai ser internado. Vai depender de ordem judicial para ser internado? Não, vai ser internado até que haja a, enquanto houver essa necessidade clínica, mas 
a partir do momento que houver a alta, não houver mais a necessidade terapêutica da internação, ele vai sair, ele não vai depender de juiz para fazer isso, o PAILI resolve tudo isso. Ele apenas faz comunicações periódicas ao judiciário.

Para fechar, aqui alguns dados.

Em dez anos de funcionamento, 554 casos acompanhados. A nossa população em Goiás é de um pouco mais de 6 milhões e meio de habitantes. Usuários em atendimento hoje 341, alguns tiveram a medida extinta, outros morreram, e tem situações das mais variadas, hoje são 341 em acompanhamento. Internações, esses dados são de anteontem, são oito, anteontem nós tínhamos oito pacientes internados em todo o estado de Goiás, internados em leitos do Sistema Único de Saúde. Não é internado em manicômio ou coisa que o valha. A reincidência gira em torno de $5 \%$ dos quais em dez anos houve dois crimes graves. Então 5\% de 500 casos, vamos arredondar, 35 episódios de reincidência, a maioria em crimes leves e dois episódios de crimes graves, um deles, inclusive, com grande repercussão até nacional.

A cobertura do programa é total, ele cobre todo o território do estado de Goiás, sem exceção. De forma que qualquer pessoa que for sentenciado em qualquer lugar do estado vai ser encaminhado ao PAILI se for submetido à medica de segurança para ser colocado onde? Num determinado lugar? Não, para ser colocado que é a casa dele, não é? E para se dar início ao trabalho que deve ser feito de acompanhamento nesses casos. Há um dado importante, vou também frisar aqui, o tamanho da equipe, uma equipe de quinze funcionários entre servidores administrativos e equipe técnica, atende toda a população em medida de segurança do estado de Goiás. Imagine então o custo financeiro de tudo isso aí, não é? Irrisório. Ele usa, faz uso da rede de apoio do SUS, da RAPS, evidentemente, mas tem sido muito importante, tem sido interessante demais o quanto tem sido fundamental o apoio da atenção primária à saúde nesses casos. Então, tão importante ou às vezes até mais importante do que um CAPS na cidade, às vezes, é ter um dispositivo potente da estratégia de saúde da família. Porque o paciente não é visto apenas como cabeça, não é? Como um problema mental, um problema de saúde mental. É visto como uma pessoa, como um cidadão que tem, enfim, diversos tipos de encaminhamento, eventualmente isso não ultrapassa única e simplesmente a atenção do sistema de saúde.

Tem alguns dados sobre a rede de Goiás, bom, é mais ou menos isso. O PAILI funciona dentro da estrutura, digamos, administrativa da Secretaria de Estado de Saúde, tem a secretaria, tem a superintendência, tem a coordenação de saúde mental, a gerência de saúde mental, ele é uma coordenação dentro da gerência de saúde mental. Não é saúde 
prisional, observe esse detalhe importante, é uma estrutura dentro da secretaria da saúde na gerência de saúde mental. O que, e a partir dali ele é um escritório que faz com que seja articulado toda a rede de atenção psicossocial, assim com a atenção primária, eventualmente como é chamada a dar esse suporte. E a partir dessa equipe se faz com que essa população de medida de segurança seja contemplada sem qualquer utilização da internação asilar. Aí tem alguns dados de contato para quem quiser, o e-mail está aí. Era isso mesmo, muito obrigado a todos. 


\section{Conferência - Políticas públicas no contexto da crise do estado de direito}

Coordenação: Prof.a Dra ${ }^{a}$. Ana Luísa Aranha e Silva - Enfermeira, Professor Doutor Associado do Departamento de Enfermagem Materno-Infantil e Psiquiátrica da Escola de Enfermagem da USP.

\section{Prof. Dr. Aldo Fornazieri}

Físico, Doutor em Ciência Política, Professor da Fundação Escola de Sociologia e Política de São Paulo (FESPSP), Diretor Acadêmico da FESPSP, Coordenador do curso de pós-graduação Globalização e Cultura da FESPSP.

Eu quero agradecer à professora Sonia Barros por ter me convidado para este evento. Quero agradecer também à professora Ana Luiza e dizer que para mim é uma honra estar aqui com vocês, na medida em que eu entendo que este movimento é um movimento fundamental para o país, principalmente pelo seu conteúdo humanístico, porque eu acho que a característica fundamental deste movimento aqui é o seu conteúdo humanístico.

E nós, que trabalhamos com ciência política, com filosofia política, entendemos que precisamos nos juntar para um processo civilizatório, principalmente tendo em vista os acontecimentos do mundo de hoje, que não são nada animadores, digamos assim. Então, desde que a vida política, a própria noção de política nasceu lá com os gregos antigos, a ideia da polis, que significava, numa tradução mais ou menos aproximada significava cidade, a polis significava a vida em comum. E hoje em dia o que nós vemos nos Estados, nos países é que essa ideia da vida comum, do interesse comum, do bem comum é uma ideia extremamente fragilizada.

Nós vivemos uma era de individualismo extremo, de desconstituição de políticas públicas, de agravamento das desigualdades. Então, com movimentos desumanizadores, como nós vimos o que está acontecendo na Europa com os refugiados, com os imigrantes e, num certo sentido, também a vitória do Trump nos Estados Unidos tem um conteúdo, um movimento, um fluxo de desumanização, quer dizer, a ideia de construir um muro num mundo globalizado. Então, de fato vivemos um momento de bastante 
perplexidade. Então, parabéns a todos por participarem deste movimento, principalmente pelo seu conteúdo. Bom, eu fui convidado para falar sobre as Políticas Públicas num Contexto de Crise do Estado de Direito, então eu fiz um pequeno roteiro para falar sobre esse assunto e esse roteiro, digamos assim, comporta tentar talvez esclarecer um pouco o que significam esses conceitos que estão propostos. Em primeiro lugar o conceito de política pública. Certamente, vocês têm uma noção do que são políticas públicas, mas eu vou tentar esclarecer um pouco mais esse conceito de política pública. Em segundo lugar, o que é o Estado de direito, quer dizer, no mundo se fala muito em Estado de direito, mas muitas vezes não se tem noção do que seja o Estado de direito. E em terceiro lugar, o que é a crise do Estado de direito, exatamente o tema que foi proposto. Bom, políticas públicas, na verdade, quando se fala em políticas públicas, nós falamos numa coisa relativamente recente na história da humanidade.

Podemos dizer que as políticas públicas começaram a aparecer no final do século 19. Nos livros de história de políticas, e política pública normalmente é relacionada também à noção de social, de Estado social, de política social, elas apareceram basicamente na Prússia, entre 1883 e 1875, sob o governo de Bismarck na Prússia, que é a região mais ou menos que abrange a Alemanha, a Áustria e assim por diante, quando começaram a acontecer greves de operários e naquele momento Bismarck editou leis chamadas leis antissocialistas. Essas leis tinham um caráter fundamentalmente ambíguo, porque, por um lado, proibiam a manifestação política e greve de trabalhadores, mas, por outro lado, tinham um conteúdo fortemente social, porque ele começou a instituir a ideia da redução da jornada de trabalho. Os trabalhadores trabalhavam 15, 16 horas, introduziu a ideia de uma remuneração mais ou menos fixa, introduziu a ideia de descanso semanal e também essa lei incidiu, de certa forma, sobre os aluguéis. Então pela primeira vez, aparentemente, na história, um governo começa a instituir políticas públicas que têm uma natureza social.

Aqui no Brasil, essa discussão também surgiu nessa mesma época mais ou menos. Vocês sabem que a República foi proclamada em 1889 e nesse contexto da Proclamação da República aconteceu uma Constituinte que fez a Constituição Republicana e, naquele momento, se constituiu um grupo particularmente ligado à doutrina positivista do sociólogo francês Auguste Comte. E era um grupo que se organizava fundamentalmente no Rio Grande do Sul em torno de um líder republicano lá que se chamava Júlio de Castilhos. E no Rio de Janeiro tinha um grupo também positivista que era ligado ao Apostolado Positivista, que eles de certa forma misturavam as teorias do Comte com uma espécie de religiosidade. E esse grupo apresentou na Constituinte um programa social, um dos mais 
avançados do mundo e, na nossa historiografia brasileira, praticamente desconhecemos esse fato. Então toda a ideia do salário-mínimo, de limitação do tempo de trabalho, da jornada de trabalho, a questão de benefícios, de saúde e assim por diante estavam naquele projeto que foi apresentado na Constituinte no final do século 19.

Não por acaso, depois dos anos 30, quando aconteceu a revolução de 1930, Getúlio Vargas instituiu, digamos assim, um programa de direitos. E, equivocadamente, normalmente se diz que Getúlio Vargas copiou esse programa de direitos que instituiu direitos trabalhistas, a CLT e assim por diante, ele teria copiado isso da Carta del Lavoro, do Mussolini, na Itália. Na verdade, é um equívoco, porque Getúlio Vargas se criou politicamente, se formou politicamente nesse contexto do positivismo liderado pelo Júlio de Castilhos no Rio Grande do Sul. Tanto é que quando morre Júlio de Castilhos, se não me engano, em torno de 1901, por aí, Getúlio Vargas era jovem, estudante de direito e ele fez o discurso fúnebre do Júlio de Castilhos. Então Getúlio Vargas já conhecia, ainda na sua juventude, todo esse contexto do conhecimento da ideia de políticas públicas e políticas sociais e assim por diante. Então ele simplesmente não copiou Mussolini, mas ele já tinha essa doutrina dos chamados direitos sociais.

Mas como é que nós poderíamos definir teoricamente a ideia de políticas públicas?

As políticas públicas, normalmente, implicam numa ação positiva do Estado. $\mathrm{O}$ que é uma ação positiva do Estado? O Estado tem que agir, tem que ser pró-ativo para que existam políticas públicas. Não existem políticas públicas sem uma pró-atividade do Estado. Então esse é o conceito básico: não há políticas públicas sem uma ação positiva do Estado. Essa ação positiva do Estado pode ser demandada simplesmente do governante, ou ela pode passar por um processo de aprovação de uma lei que institui a política pública mediante os representantes do povo, que são os parlamentares e assim por diante. E o que visam atender, qual é o objetivo de uma política pública? O objetivo de uma política pública é atender determinados carecimentos da sociedade, determinadas necessidades da sociedade.

Então, por exemplo, vocês trabalham aqui com saúde mental e tem pessoas que demandam serviços de saúde mental. Então, essas pessoas que demandam serviços de saúde mental são portadoras de determinados carecimentos. Assim como a educação é um carecimento, ou outras esferas do direito social são carecimentos e toda política pública visa atender, fundamentalmente, carecimentos humanos. E por que se faz a política pública? Porque se reconhece que as pessoas, por si sós, no contexto do mercado, das relações do mercado, não são capazes de dar conta dos seus carecimentos. Então o processo histórico vai estabelecendo o reconhecimento de que é um care- 
cimento fundamental e que aspessoas são portadoras de um carecimento fundamental que merece ser protegido publicamente. Esses carecimentos têm fundamentalmente duas dimensões, uma dimensão de curto prazo ou uma dimensão de longo prazo. Por exemplo, quando uma pessoa fica desempregada e precisa do salário-desemprego é um carecimento de curto prazo. Uma pessoa portadora de necessidades demandadas, por exemplo, isso que vocês trabalham aqui, que é a saúde mental, é um carecimento de longo prazo, portanto ela é portadora de uma necessidade permanente de proteção. A licença-maternidade é um carecimento de curto prazo, uma pessoa que fica inválida por conta de um acidente tem um carecimento de longo prazo. Então, os carecimentos têm, basicamente, essa dupla conformação: carecimentos de curto prazo e carecimentos de longo prazo. E as políticas públicas, normalmente, se definem em função do tipo de carecimento. Bom, as políticas públicas então são orientadas para atender essas necessidades e, normalmente, essas necessidades são reconhecidas como direitos das pessoas. E essa ideia de direitos surge exatamente no trânsito do século 19 para o século 20. Como é que era feito anteriormente, digamos assim, esse atendimento a determinados carecimentos? Eles eram feitos a partir daquilo que se chamava, digamos assim, assistência que não reconhecia os direitos, era caridade.

No século 19 se praticava, fundamentalmente, a caridade. A partir do início do século 20, esses carecimentos passam a ser reconhecidos como direitos das pessoas. $\mathrm{E}$ essa ideia de que os carecimentos são direitos se firmou, principalmente, no entre guerras. Vocês sabem que em 1930, por aí, ocorreu uma crise mundial, a chamada Grande Depressão, com milhões de pessoas empobrecidas, desempregadas e assim por diante. E tanto na Europa quanto nos Estados Unidos, principalmente, começaram a surgir políticas públicas para garantir direitos. E no contexto do final da Segunda Guerra Mundial surgiu na Europa aquilo que se chama Estado do bem-estar social. Esse Estado do bem-estar social vai constituir direitos não mais entendidos como caridade, mas exatamente como direitos das pessoas. Esses carecimentos passam a ser entendidos como direitos.

Como é que se instituem as políticas públicas?

As políticas públicas têm alguns atores fundamentais para que elas se formem. Em primeiro lugar é o movimento das próprias pessoas portadoras de carecimentos. Então, no mundo do trabalho, no mundo da educação, no mundo da saúde e assim por diante, ocorreram lutas e essas lutas demandaram proteção do Estado. Uma outra forma pela qual se instituem políticas públicas é através da disputa político- partidária, quer dizer, os partidos precisam ganhar votos para ascender ao poder e nesse sentido também passaram propor políticas públicas, por exemplo, na Europa surgiram os chamados 
partidos socialistas, social-democratas e eles defenderam políticas públicas para que elas fossem aprovadas nos parlamentos europeus. O terceiro ator importante da formulação de políticas públicas surge dentro do próprio Estado, a burocracia estatal. Tendo em vista que a burocracia estatal tem um interesse também na expansão do Estado, ela também passou a formular, a teorizar e a propor políticas públicas. Então, de modo geral, nós temos esses três grandes atores no processo de constituição de políticas públicas. Em primeiro lugar, os movimentos trabalhistas e sociais, por exemplo, o movimento social como o de vocês, que vai fazer demandas para o Estado. Em segundo lugar, os partidos políticos e em terceiro lugar a própriaburocracia estatal. Então se tem que, normalmente, esses três atores são, digamos assim, formuladores das políticas públicas.

Qual é o caráter de uma política pública?

Quer dizer, então ela visa atender, fundamentalmente, carecimentos humanos, mas o seu caráter é distributivo ou redistributivo. Por que ela tem um caráter distributivo ou redistributivo? Porque para atender a maioria das políticas públicas se requer recursos e, convenhamos, você não vai tirar recursos daquele que é portador do carecimento para devolver o recurso a essa mesma pessoa que é portadora de carecimentos. Então a política pública, de modo geral, tem essa natureza distributiva, redistributiva e o processo distributivo ou redistributivo se dá, fundamentalmente, pela via dos impostos. Quer dizer, os impostos têm que ter um caráter progressivo, o que significa que você vai tirar de quem tem mais para dar para aqueles que são portadores de carecimentos, para aqueles que têm menos. E aqui eu queria fazer uma pequena nota nisso, porque essa ideia do caráter distributivo ou redistributivo da política pública, fundamentalmente, na Europa veio a ser conhecida como Estado do bem-estar social. Só que aqui no Brasil nós temos uma enorme perversidade e ela se dá, digamos assim, no caráter regressivo do nosso sistema tributário.

O que se faz aqui no Brasil, você tira de quem tem menos para dar a quem tem mais, quer dizer, todo mundo que estuda o sistema tributário do Brasil sabe disso, quer dizer, tira-se de quem tem menos para dar para quem tem mais. E muitas vezes os próprios movimentos sociais, movimentos corporativos patrocinam políticas elitistas, por incrível que pareça. Por exemplo, quando se demanda a ideia de que as universidades públicas têm que ser públicas e gratuitas para todos, você também está instituindo privilégios, porque quem estuda em universidade pública normalmente é gente rica, gente que tem dinheiro e assim por diante. Então, vejam o seguinte, eu sou a favor do ensino gratuito na universidade pública, mas para aqueles que são portadores de carecimento e não para todo mundo, acho que a pessoa que tem condições deveria pagar e assim 
por diante. E mesmo no setor público, o que nós vemos são muitos privilégios, inclusive defendidos pelos movimentos sindicais, pelos partidos políticos de esquerda e assim por diante. Então, esta é uma perversidade que tem no Brasil e isso tudo deveria serdiscutido.

Bom, mas voltando à questão das políticas públicas, podemos dizer que nós temos, digamos assim, dois tipos, ou duas, ou três, ou quatro tipologias de políticas públicas. Temos as políticas públicas estruturantes e as políticas públicas compensatórias, de um lado. O que é uma política pública estruturante? Por exemplo, uma política pública de educação e saúde e assim por diante é uma política pública estruturante, porque ela, digamos assim, cria insumos para a melhoria permanente da sociedade. Então ela, digamos assim, é uma política pública que muda a qualidade da sociedade. E temos políticas públicas compensatórias. Podemos dizer que o Bolsa-Família, por exemplo, é uma política pública compensatória, por quê? Embora ela tenha um elemento estruturante, eu vou falar porque. O Bolsa-Família demanda alguns requisitos e é compensatório, porque visa solucionar um problema que é temporário, que aquela pessoa está na pobreza, numa condição de pobreza, ela tem filhos pequenos e assim por diante, então é uma compensação, ou o próprio Prouni é uma política pública compensatória. Mas por que eu diria que o Bolsa-Família também tem um elemento estruturante? Porque certamente os filhos das famílias que recebem o Bolsa-Família não vão viver mais na condição em que os pais viveram, eles vão vier numa condição melhor, então tem um elemento estruturante. Então todas as políticas que são mais ou menos de longo prazo, que incidem para mudar de forma permanente a qualidade da sociedade têm uma dimensão estruturante. As outras, que são de mais curto prazo, são compensatórias. Uma outra divisão que se faz em relação às políticas públicas diz respeito se elas são universalistas ou focais.

Por exemplo, a política pública na qual vocês estão envolvidos é uma política focada, ela é focal, por quê? Porque ela atende um determinado público específico, enquanto, por exemplo, a ideia de que o direito à saúde deve ser para todos é uma política pública universal. Então existe também essa divisão. Então temos duas grandes divisões, ou ela é compensatória ou é estruturante, ou ela é universalista ou é focal. Então aqui temos as tipologias das políticas públicas. Bom, um outro elemento em relação às políticas públicas diz respeito a esse fato de que elas são um direito. E, normalmente, vejam o seguinte, existe duma subdivisão de direitos ao longo da história. Não sei se vocês conhecem um autor chamado Norberto Bobbio, foi um filósofo político italiano que morreu recentemente, ele tem um livro chamado A Era dos Direitos e nesse livro ele estabelece, mais ou menos, uns setenta direitos. Os direitos podem ser políticos, os que dizem respeito aos 
direitos de liberdade, eles podem ser direitos civis. E também citou na época os direitos políticos, que ele chamou de direitos de igualdade e assim por diante. E aí, a partir do século 20 surgem os direitos sociais.

Normalmente, a ideia de política pública se relaciona aos direitos sociais. E mais ultimamente surgiu uma outra classificação de direitos que diz respeito à ideia de direitos difusos. Direitos difusos ou direitos conexos e aí, por exemplo, temos toda a questão da política para as mulheres, as políticas ambientais, o direito de viver num mundo ambientalmente adequado, os próprios direitos LGBTT e assim por diante, que são chamados direitos difusos. Eu só queria ressaltar e enfatizar que as políticas públicas de um modo geral se referem a direitos sociais, embora elas possam se referir também a outros tipos de direitos. Como é que são garantidas as políticas públicas? Existem, basicamente, três formas de garantia das políticas públicas.

Em primeiro lugar, através de um auxílio pecuniário, quer dizer, a pessoa recebe monetariamente o recurso, por exemplo, aposentadoria. Ou outras formas que implicam no recebimento de um benefício pecuniário através de serviços, que me parece que é o caso de vocês, então o Estado mantém uma série de serviços ao portador de carecimento. E em terceiro lugar através da lei, por exemplo, a Lei Maria da Penha é uma política pública, quer dizer, a proteção das portadoras de carecimento, no caso, mulheres agredidas, se dá através do processo jurídico policial, digamos assim, então, na lei. Claro que normalmente todas as políticas públicas são vinculadas a leis, mas tem algumas políticas públicas que implicam só na lei, e a pessoa que sente a necessidade de fazer uso, demandar a proteção, ela recorre à lei, à autoridade, ou à autoridade policial ou à autoridade judiciária. Então, de modo geral, é através desses 3 elementos que são garantidas as políticas públicas.

Falado isso, eu queria falar rapidamente sobre o que é o Estado de direito. Vejam o seguinte, aqui tem toda uma história política por trás desse conceito de Estado de direito. Essa história do Estado de direito começa principalmente na Inglaterra, mais especificamente no século 17, quando aconteceu a Revolução Inglesa, quando em 1630, por ser uma guerra civil tendo de um lado o Parlamento e de outro lado a Monarquia dos Stuart. Aí o Parlamento derrubou a Monarquia, cortaram a cabeça do rei e tudo o mais, depois, em 1688, tivemos a chamada Revolução Gloriosa, quando o Parlamento coroou o rei. Então, nesses anos todos, surgiu uma série de debates na Inglaterra que estabeleceram mais ou menos o seguinte, vocês sabem que nos séculos 16 para 17 surgiram na Europa aquilo que se chamava as Monarquias Absolutistas. Eram monarquias que tinham o poder absoluto, o rei tinha o poder absoluto, tanto é que na França o famoso 
Luís XIV falou "o Estado sou eu”, quer dizer, ele era o poder, os reis tinham todo o poder, se dizia que os reis eram reis por direito divino e assim por diante.

O Estado de direito surge como um movimento para a limitação do poder do rei, então é essa a origem do conceito de Estado de direito. Estado de direito significa um poder limitado. E essa ideia do Estado de direito se vinculou depois, tanto na Inglaterra, mas principalmente nos Estados Unidos, quando eles proclamaram a independência e fizeram a sua constituição, à ideia de que o poder deveria ser constitucionalizado, não há um poder sem limite, não há um poder tirânico, onde a pessoa do poderoso decide o que fazer, mas deve seguir uma constituição. E essa constituição limita o poder do soberano, daquele que exerce o poder. Essa ideia foi muito trabalhada pelos federalistas norte-americanos, no contexto do surgimento da constituição norte-americana em 1786, e surgiu aquela que era uma ideia que não é nova, era uma ideia antiga, que já existia de certa forma na época da república romana antiga, a ideia da divisão do poder em três ramos.

Modernamente, o filósofo político Montesquieu elaborou essa ideia da divisão de poderes e depois ela foi bastante teorizada nos Estados Unidos. A ideia é de que existem três poderes, o poder executivo, o poder legislativo e o poder judiciário. E na teoria constitucional norte-americana se trabalhou muito a ideia de que deveria existir um equilíbrio e um controle desses poderes, um poder controlava o outro. O executivo é controlado pelo legislativo e judiciário, o executivo e o judiciário também controlam o legislativo e assim por diante. Então, a ideia de um equilíbrio e de um controle, aquilo que os norte- americanos chamam de freios, pesos e contrapesos, exatamente para limitar o poder. E por que Estado de direito? Porque a ideia do Estado de direito é que o poder tem um limite e esse limite são os direitos das pessoas. Quer dizer que quando você fala em Estado de direito, você está dizendo "olha, o poder tem um limite e esse limite são os direitos das pessoas”. Então aí temos os direitos fundamentais políticos e civis, que são os direitos de liberdade de organização, de expressão, de reunião de proteção e assim por diante. O Estado não pode violar esses direitos e se alguma autoridade do Estado viola esses direitos, ela é passível de punição. Então, provavelmente, ninguém de vocês aqui viveu na época da ditadura militar, quer dizer, teve todo um movimento político para a defesa do Estado de direito. O que significava? Que o Estado não podia chegar nas pessoas, cometer uma arbitrariedade, prendê-la indevidamente ou torturá-la e assim por diante. Então, essa era a luta pelo Estado de direito, quer dizer, quando você fala em Estado de direito, você está falando em direitos das pessoas. O Estado de direito implica também um outro conceito, que é o império da lei, ninguém está acima da lei. E implica 
também a noção do Estado republicano, que é aquela ideia da divisão do poder em três poderes. Então esse é o conceito básico do Estado dedireito.

E, finalmente, então vamos para essa temática do tema proposto, que são as Políticas Públicas no Contexto da Crise do Estado de Direito. Bom, vejam o seguinte, nós vivemos, evidentemente, um momento conjuntural de crise, com todo esse processo de impeachment da Dilma e a ascensão do governo Temer e por que se fala em crise do Estado de direito? Eu diria que se fala em crise do Estado de direito em três dimensões.

A primeira dimensão é porque as democracias, de um modo geral, pararam de funcionar, esse é o consenso entre os cientistas políticos, quer dizer, não é só a democracia brasileira que parou de funcionar, mas as democracias ocidentais em geral. E por que se diz que elas não funcionam? Em primeiro lugar, porque elas perderam a legitimidade. As pessoas não se reconhecem mais nessas democracias por aí, porque as democracias passaram por um processo de isolamento, de ilhamento e elas se colocam acima das pessoas, sem conseguir atender às demandas e os direitos das pessoas. Então existe o problema de crise das democracias.

Em segundo lugar, existe aquilo que alguns teóricos, particularmente, um filósofo italiano chamado Giorgio Agamben chama de Estado de exceção permanente. O que é o Estado de exceção permanente? Eu diria o seguinte, quer dizer, o judiciário não obedece mais a lei escrita estabelecida e ele cria uma legislação sem estar escrita, de forma permanente, porque ele age em cima dos fatos. Aqui no Brasil tem toda essa discussão em torno do procedimento da Lava-Jato, do que a Lava-Jato vem fazendo, por exemplo, as conduções coercitivas, a lei não permitiria, no entanto, quer dizer, o Juiz Moro cria uma legislação acima da Constituição e acima das leis. Esse processo do Estado de exceção, só para pontuar, rapidamente, surgiu nos Estados Unidos no contexto dos atentados de 11 de setembro, quando foram editados os chamados Atos Patrióticos, pelo Presidente Bush. Quer dizer, era uma legislação que violava os direitos das pessoas, consequentemente constituindo um Estado excepcional. Nesse Estado de exceção permanente, o juiz julga a partir dos fatos, ele cria uma lei não escrita a partir do fato. E essa era uma prática usada pelo regime nazista na Alemanha, que se chamava a Lei do Movimento, quer dizer, você na prática vai revogando a lei escrita e vai instituindo uma nova lei, a partir da decisão discricionária, arbitrária que o juiz toma em função do acontecimento, em função do fato. Quando acontece isso, todo mundo corre riscos, porque não vale mais a lei, não vale mais a Constituição e de certa forma passa a valer a vontade arbitrária do juiz. Então, esse é o segundo elemento da crise do Estado de direito. 
E o terceiro elemento da crise do Estado de direito, e esse é um problema que ocorre, fundamentalmente, no Brasil hoje, embora aconteça também em outros países da América Latina, diz respeito a esse movimento que o governo Temer está instituindo no Brasil, que é um movimento de confrontação aquilo que eu chamo do espírito da Constituição de 1988. Vocês sabem que a Constituição de 1988 foi definida pelo Ulisses Guimarães como a constituição cidadã. Ela é uma constituição que visa criar uma espécie de um colchão de segurança social, de seguridade social, de segurança social das pessoas, portanto essa segurança social seguia garantida por políticas públicas. E essa emenda chamada PEC 241, ou PEC 55 agora no Senado, ataca exatamente esse espírito da Constituição de 1988. E eu entendo que isso é extremamente grave, porque um governo que nasce, do meu ponto de vista, de uma ilegitimidade, porque por pior, por ruim que fosse o governo Dilma, o fato é que eu entendo que não havia elementos legais para fazer o impeachment. Nesse sentido, ao menos é a minha opinião, o que houve no Brasil foi um golpe. E as gravações mostram ali, várias gravações, principalmente as do Sérgio Machado, que houve toda uma articulação de setores do PMDB, particularmente, para fazer o golpe, para acontecer isso que vocês estão vendo que está acontecendo agora. Quer dizer, uma tentativa de barrar a Lava-Jato. As gravações do Sérgio Machado, que era diretor da Transpetro mostram claramente isso, que o objetivo era parar a Lava-Jato. E agora, vocês veem todas essas manobras que estão acontecendo no Congresso, confirmando que aquelas gravações eram verdadeiras e que uma das intenções principais era exatamente barrar a Lava-Jato para salvar o pescoço de centenas de políticos.

Bom, vocês poderiam me perguntar o seguinte, dizer, como o governo Dilma estava ruim, a Dilma não conseguia governar e assim por diante, teria alguma outra saída que não fosse o impeachment? Eu diria que teria, eu apontaria duas saídas. Em primeiro lugar, um pacto de todas as forças políticas tentando garantir uma governabilidade mínima para a Dilma, para que ela chegasse a 2018 e a segunda alternativa era uma renúncia, e aí eu acho que todos os partidos erraram, inclusive o PT e inclusive a Dilma e assim por diante, seria uma renúncia da Dilma e do Temer, uma renúncia conjunta e isso provocaria uma nova eleição presidencial automaticamente, sem passar por emenda constitucional e assim por diante. Ninguém propôs isso aí, então havia, existiam saídas melhores. Bom, então temos esse governo, que é fruto de uma ilegitimidade e um governo que ataca as políticas públicas e vocês, provavelmente, eu não sei, especificamente, a situação de vocês, mas, provavelmente, vocês já estão sofrendo os efeitos desses ataques à política pública que vocês estão levando adiante. Quer dizer, esse é um ataque generalizado, toda a área social, pública vai sofrer se essa PEC for aprovada em definitivo e nesse sentido 
nós teremos, inequivocamente, um retrocesso social no Brasil. Teremos um retrocesso histórico de grandes proporções, e aquilo que nós vínhamos construindo nos últimos 30, 40 anos vai retroceder terrivelmente e vão ser demandadas várias lutas para que depois haja uma recuperação.

Como enfrentar esse processo da confrontação do espírito da Constituição cidadã e da ideia da constituição de um mínimo bem-estar social no país? Eu entendo que é através da luta e da organização, não tem outro jeito, porque eu entendo que esse congresso que está aí é um congresso pior, um dos piores congressos da nossa história, é um congresso conservador, um congresso antissocial, um congresso que se importa apenas com interesses de grupos particulares. E não vai ser esse congresso que vai, digamos assim, salvar as políticas públicas. Vocês veem, por exemplo, mesmo nessa questão do aborto, o Supremo Tribunal Federal entendeu o que é o direito do aborto e agora o Presidente da Câmara, o Rodrigo Maia desencavou um projeto de lei para proibir o aborto. Então, tanto no campo dos costumes, quanto no campo das políticas públicas, das políticas sociais e assim por diante nós estamos caminhando, inequivocamente, para um retrocesso. Bom, os partidos de esquerda estão fragilizados, o próprio PT está desmoralizado perante a opinião pública, então, do ponto de vista dos partidos, nós temos pouca capacidade de reação, a sociedade tem pouca capacidade de reação. E qual é o outro risco? O outro risco que eu entendo é que cada movimento social vá lutar pelo seu interesse particular. Quer dizer, se não houver uma união dos movimentos sociais, o rolo compressor vai passar, porque um movimento social lutando isoladamente, separadamente, tem pouca força. Então eu entendo que deveria haver uma união dos movimentos sociais, uma união com o que restou dos partidos progressistas para fazer frente a esse rolo compressor da desconstituição das políticas públicas, da desconstituição das políticas sociais no Brasil. Isso é muito difícil, tanto aqui no Brasil quanto, principalmente, porque há um contexto internacional extremamente conservador. Pelo que nós vimos nos Estados Unidos, pelo que vai acontecer na Europa, provavelmente, uma vitória de partidos de extrema direita e antissociais, anti civilizatórios, eu diria. A própria questão ambiental, vocês veem aí que o Trump está confrontando a própria política ambiental, o que é um grande risco para toda a humanidade. Então, digamos assim, esse é o problema.

Então, a única coisa que eu poderia dizer é que não há saída a não ser lutar. Não há saída a não ser a mobilização, porque nós temos que acreditar em nós mesmos, porque o sistema político está falido, está corrompido, os partidos não têm credibilidade. Para vocês terem uma ideia, uma pesquisa recente mostra que os partidos políticos têm apenas $7 \%$ de apoio positivo, uma pesquisa sobre a própria democracia mostra que a 
maioria da sociedade brasileira prefere um regime de força, um regime ditatorial, então a própria democracia corre riscos nesse sentido. Então a única recomendação que eu tenho para vocês é o seguinte: se mobilizem, se organizem e lutem. Eu não vejo outra saída neste momento. Era isso o que eu queria dizer para vocês e vamos tentar fazer um debate para falar de outras questões que ficaram fora desse contexto da exposição.

Muito obrigado. 


\section{Mesa redonda - Ações dos serviços territoriais para inclusão social}

Coordenação: Prof. ${ }^{a}$ Dr. ${ }^{a}$ Maria do Perpétuo S. S. Nóbrega - Enfermeira, Professora Doutora do Departamento de Enfermagem Materno-Infantil e Psiquiátrica da Escola de Enfermagem da USP.

\section{Prof. Dr. Benedetto Saraceno}

Médico, Psiquiatra, Ex-diretor do Departamento de Saúde Mental da Organização Mundial da Saúde, Docente da Universidade de Genebra, Suíça e Coordenador do Curso de Mestrado Internacional de Políticas e Serviços em Saúde Mental da Universidade Nova de Lisboa.

\section{Obrigado.}

Falar das coisas, dos serviços territoriais para inclusão social, eu acho que não é, não consiste, acho que a missão que nos dá, não é tanto de apresentar uma lista, como dizem os ingleses um cheque list, a lista de ações, que eu acho que são óbvias e são muito bem conhecida para todos, para os que trabalham já, no CAPS,......tem que ter inclusão social, são óbvias, são ações óbvias, podemos apresentar uma lista eu estou seguro que $80 \%$ do que colocarmos na lista tem $100 \%$ do consenso, provavelmente há $20 \%$ com alguma discrepância; eu acho que a maneira que eu vou falar, do SUS, dos serviços territoriais para inclusão social, é diferente, e mais do que tudo, de falar de qual tem que ser a visão estratégica do serviço territorial, qual tem que ser o princípio (...), com tantas tecnologias, que o serviço tem que oferecer ao usuário, porque afinal as tecnologias são muito parecidas, o que não é parecido entre um CAPS e outro, ou entre o CAPS e um serviço mais tradicional da psiquiatria tradicional, mas não falando da má psiquiatria, e sim falando da boa psiquiatria tradicional, também há uma boa psiquiatria, médica tradicional, para o CAPS; não existe o CAPS sem referência cultural, estratégica, é mais o que se ouve, que não é simplesmente oferecer uma boa psiquiatria biomédica de boa qualidade, tem que oferecer uma boa psiquiatria, tem, e as vezes não tem essa capacidade porque eu tenho minhas dúvidas, pela capacidade da prescrição farmacológica de boa 
qualidade, o uso racional dos medicamentos, eu acho que muito dos CAPS não tem essa capacidade, então os que têm, tem o dobro de trabalho, saber oferecer boa psiquiatria tradicional, de saber e ter uma estratégia com a boa psiquiatria de boa qualidade, que tem a ver com a saúde mental, tem a ver com a intervenção social, tem que ser com a promoção de direitos do usuário, tem que ser um local de defesa e promoção de direito e de inclusão social.

Vamos ver quais são, podiam ser os grandes princípios que tem que estar no estatuto ideal de um CAPS de boa qualidade, primeiro de todos: importante, temos hoje, uma situação que não é a mesma de somente internos, a situação em que o tratamento de enfermidades crônicas, câncer, cardiovascular, diabetes, hipertensão, aids, se diz assim aids? sim aids, tuberculose, enfermidades crônicas efetivas ou não transmissível como câncer ou diabetes, há 20 ou 30 anos para pessoas que tem câncer ou diabetes, hipertensão, cardiovascular, tuberculose, teria como referência o tratamento de enfermidades crônicas, muitos anos, com largo tempo de sobrevivência com 20, 30, 40 anos com hipertensão, com diabetes, a referência há 30 anos era hospital, o tratamento estava em hospital, em hoje $90 \%$ dos dias de vida de pessoas que já tenham uma grave enfermidade crônica, cardiovascular, diabetes, câncer, aids, tuberculose, 90\% dos dias vividos, por essas pessoas enfermas se passa fora do hospital, se passa dentro um tratamento que não é hospitalar, é dentro de ambulatórios da comunidade. É muito importante, por que muito importante? Porque estamos há quase 30, 40 anos a falar de psiquiatria territorial, de sair do hospital, a psiquiatria era a vanguarda da medicina.

Hoje há uma medicina social, das enfermidades crônicas que tem uma visão totalmente comunitária e nós estamos correndo o risco de retroceder das conquistas e das lutas antimanicomiais, mas a vanguarda está um pouco dentro do campo da medicina, e dentro do campo da medicina há outros que serão a vanguarda, isso é importante, é importante porque é um lado que temos que defender a conquista e de outro temos um ângulo que não se ajuda e, nesse momento, a medicina inteira está se movendo desde o hospital à intervenção mais comunitária, e não estamos mais sós, não estamos mais sozinhos, essa é uma premissa.

Quais são os principais vetores de um serviço comunitário territorial?

Número um, outro dia estávamos num teatro aqui em São Paulo, para disseminar a defesa do programa braços abertos, braços abertos é um programa inspirado no modelo de "housing first", ou seja, a moradia vem primeiro no tratamento, a moradia, intervenção social, alimentação, cidadania, é a intervenção principal que vem "housing first" primeiro casa, depois tratamento, se iniciaram estudos clínicos de todos os lados, para mostrar 
que todos os pacientes que estavam no braço do estudo, no tratamento "first" depois casa, foi um fracasso, e todos os pacientes que estavam no braço moradia first e depois tratamento, foram bem, então o modelo "housing first" está muito difundido. E no caso de braços abertos, first é casa, moradia, mas em geral, a mudança do paradigma, o primeiro princípio de um serviço territorial, é cidadania first. Porque eu disse outro dia, há muitas diferenças em dizer temos psicóticos brasileiros, ou dizer teremos brasileiros psicóticos, então a diferença é grande, não é julgar com palavras, primeiro sempre é que eu sou brasileiro, sou brasileiro com psicose, sou brasileiro pobre, sou brasileiro negro, sou brasileiro rico, eu sou brasileiro, depois cidadão, cidadão brasileiro.

A psiquiatria clínica biomédica pensa que seus pacientes são psicóticos como brasileiros, nós outros pensamos que nossos usuários são brasileiros psicóticos, é um princípio fundamental, o serviço como elemento constitutivo, fundamental, prevalente, a busca da cidadania, a defesa da cidadania, a promoção da cidadania.

Segundo princípio do território: A defesa do direito formal do usuário, o que são direitos formais? Os direitos formais são direitos substanciados, direitos formais são: direito a votar, direito a ter documentos, direitos constitucionais, e a cultura da psiquiatria progressista norte americana, ou anglo saxônicas, dá muita ênfase aos direitos formais, da defesa dos direitos formais, menor ênfases nos direitos substantivos, o que quer dizer direitos substantivos? É fundamentalmente, direitos formais, são direitos negativos, não ser maltratado, não ser, não sei, não receber tratamento adequado, direito a não ser exposto a uma violação, e tem os direitos substantivos que são direitos positivos, o cidadão não somente tem direito a não ser maltratado, tem também direito a ser bem tratados, a gente tem direitos negativos e tem direitos positivos, muitas vezes o CAPS poderiam ter a tendência a defender somente os direitos negativos, ou seja, evitar violação grave dos direitos dos pacientes mas não tem a capacidade de promover direitos positivos, que é promover cidadania, que é promover direitos ativos, esse é o segundo princípio de todos, defesa e promoção de direitos negativos e positivos, formais e substantivos.

Princípio número três: Eu não estou mencionando, todavia, a qualidade da intervenção clínica, não está no primeiro princípio, o primeiro princípio é cidadania first, segundo princípio é defesa do direito positivo e negativo. Terceiro princípio de todos: empowerment, como se diz empowerment em português? (público responde: empoderamento) empoderamento, processo de empoderamento da família, do usuário, que não é óbvio, não é um blábláblá, que todo o sistema está em favor do empowerment; nós sempre estamos, demasiadas vezes, seguindo membros com a representação dos usuários 
que são uma minoria, e as vezes uma minoria folclórica, desculpa a franqueza; eu venho da tradição de 1968 europeia, estudante de medicina, na rua, revolucionário, eu venho de uma família da alta burguesia da Itália, família rica, de direita. Eu sou estudante de esquerda, na rua, na revolução, e a burguesia furiosa, a burguesia, furioso pelo burguês, protegido socialmente. Seu pai é uma pessoa importante.

Uma coisa, estava dizendo, éramos uma grande parte de 1968 na Europa composta por burguesia, e filhos da burguesia, e nessa universidade sempre estavam os obreiros, místicos, tinha um obreiro, em uma mesa com 50 estudantes, um obreiro, porque éramos revolucionários, com um obreiro, um único. Os psiquiatras progressistas tem as mesmas características, um paciente, um usuário, dois usuários, fala e todos aplaudem, HUU..; mas o problema é outro né, é o empowerment, quando a presença dos usuários tem o poder de modificar a estratégia de funcionamento do CAPS, isso é um poder, não é somente um usuário que fala e todos são entusiastas, o problema é a capacidade do usuário de ter um papel na qualificação, no horário de funcionamento, a que horas estão os médicos, quando vem a gente, quando será essa visita domiciliar, ou queremos mais visitas domiciliar, ou seja, a contribuição do familiar e do usuário na planificação e gestão, isso é empowerment, não somente a presença, é poder, poder como diz até no conselho da administração, no conselho da administração tem um voto, dos votos que estão representando o usuário. Terceiro princípio, empoderamento.

Quarto princípio: A busca de recursos e alianças, se queremos ser mais que um bom centro de psiquiatria, necessitamos alianças intersetoriais, no setor médico, fora do setor da saúde com outro setor, médicos com organizações sociais, termos alianças, a busca de recursos. (meu livro que não se encontra mais nesse país, porque se acabou, "Libertando Identidade" um livro complicado,). E um exemplo, vocês todos devem ter lido o livro Robinson Crusoé, apesar de ser um livro para adultos, todos as crianças pudemos ler, sábio Robinson Crusoé, e Robinson, o que disse Robinson? Robinson disse: Eu estou na Ilha, e não há nada, segundo dia um passeio circular na Iha e maravilha, há água, e no terceiro dia há frutas, e depois há pássaros para caçar, e depois em um dia, sexta-feira, encontra um homem, há um homem, não que tenha vindo caminhando durante a semana não, é uma ilha, é a realidade, é a mirada de Robinson, que em princípio tem uma mirada seca que a ilha está vazia, não há nada; mas para os psiquiatras que estão encerrados, vendo o CAPS, são como o Robinson, dizem: aqui não há nada, não há nada, não há recursos, e Robinson tem que marchar, atravessar a ilha e descobrir que há água, que há frutas, que há pássaros que há homens e mulheres. E finalmente, o CAPS que está fechado, não vê, tem uma mirada seca, e o CAPS 
que está aberto é um CAPS que descobre recursos, descobre alianças. O CAPS tem o paradigma de reabilitação psicossocial, como o paradigma de referência; a demais a reabilitação em si é uma visão, a reabilitação não é entretenimento de pacientes que pintam, bailam, cantam, fazem esculturas (aplausos do público), é pode ser, pode ser, todos queremos cantar, bailar, mas a reabilitação é a reconstrução da contratualidade social do cidadão, então um programa de reabilitação tem um eixo, que é, casa habitação, vivenda, habitat, um eixo que é vida social, intercambio, aprendizado, e um eixo que é profissional, ocupacional, laboral.

Um programa de reabilitação tem que estar construído sobre esses 3 eixos, claro que se o paciente tem 80 anos, o problema não será o profissional, mas será social de intercâmbio, mas se o paciente tem 18 anos, sim claro, o lazer, mas ocupacional. Claro, se adaptará com cada paciente, esses são os 3 eixos, não é somente um problema de entretenimento artístico, é um problema de contratualidade social, por último, o último princípio de todos é da construção das identidades, da identidade de psicótico, da identidade de médico, da identidade de profissional, identidade familiar, identidades matam, e por identidades se mata, "los servos matam os croatas, los turcos matam lo tutsi”; porque nós outros não nos matamos, não necessitamos de reabilitação psicossocial, porque, porque teremos muitas identidades, eu sou homem, marido, pai, avô, psiquiatra, profissional, pintor porque gosto de pintar, sou muitas coisas, e tantas coisas sou, tanto menos sou constrangido numa única identidade, louco, psicótico, mas faz muitos anos que o homem é rico de identidade, a cidadania tem aumentado as identidades, a uma identidade que garantisse a riqueza das identidades, ela é identidade dos cidadãos, brasileiros firsts. Conclusão, tenho um minuto (risadas da plateia). A conclusão, eu digo como uma citação de um grande amigo, Franco Rotelli, o melhor CAPS é o CAPS vazio, entras nesse CAPS e não há nada, porque estás dentro da comunidade, agora é uma provocação, eu não gosto de dizer qual é o melhor, é o CAPS que vai visitando, que está todo disperso na comunidade, esses são os principais vetores, depois vem a lista, bem conhecida das tecnologias que vamos aplicar para cada um de nossos pacientes.

Obrigado!

\section{$\operatorname{Dr}^{\mathrm{a}}$ Giovanna del Giudice}

Médica, Psiquiatra, Presidente da Conferenza Permanente per la Salute Mentale nel mondo Franco Basaglia, Trieste - Itália. 
Bom dia a todos!

Então vamos retomar a continuidade dos trabalhos. Eu sinto muito que o Saraceno tenha ido embora, porque eu vou retomar diversas questões ditas por ele e creio que eu vou fazer exatamente aquilo que ele não queria fazer, porque eu vou falar de dispositivo organizativo institucional e que pode colocar em discussão, a partir da concretude desse dispositivo e dessa organização de práticas, que pode colocar em discussão o paradigma médico, biológico e hospitalar.

Eu vou falar então, mas sem nenhuma arrogância, sobre um serviço territorial 24 horas, que são aqui os casos de vocês. Eu vou falar porque na minha experiência italiana, mas, sobretudo triestina, nós consideramos que esse dispositivo produz, isto é, pode produzir inclusão e também consideramos que é a única alternativa que nós encontramos no nosso país que permite viver sem manicômios. Trieste vive sem manicômios há 36 anos. O CAPS 24 horas é um lugar de responsabilidade terapêutica em relação a uma demanda territorial determinada e definida. Nesse sentido, não é apenas responsável pela saúde dos pacientes que vivem naquele território, mas também pelos seus familiares e pelos micro contextos nos quais eles estão vivendo. E se fazer responsável pela saúde dessas pessoas e de seus familiares, do seu contexto social, significa colocar em movimento estratégias compondo um percurso em relação a direitos e necessidades, que muitas vezes se apresentam como antagonistas, que se coloca então como desafio das práticas. Mas esse serviço é responsável, isto é, deve se sentir responsável, no sentido de responsabilidade terapêutica, pela comunidade no seu sentido geral e assim deve promover ações de saúde mental a essa comunidade. Mas também deve ser responsável, deve se sentir responsável em relação aos problemas complexos que muitas vezes existem no território dado, problemas que influenciam a vida das pessoas e, portanto, os processos de saúde e doença.

Porque nós sabemos a partir das nossas práticas que a única possibilidade para percursos de saúde e de alguma forma, como também disse Saraceno, é trabalhar contemporaneamente com os indivíduos e as coletividades. A segunda questão é que o CAPS é um lugar de responsabilidade e de acolhimento e responsabilidade em relação a toda demanda daquele território, sem seleção, mesmo em relação à determinadas demandas, vai ser importante depois que nós possamos acompanhá-la também a serviços mais específicos frente as suas necessidades. Portanto, CAPS deve ser um lugar de acolhimento e de "presa in carico"... Me desculpem, que eu tinha esquecido no parágrafo anterior, "presa in carico" como colocamos ontem, é um termo de difícil tradução literal e tem 
sido traduzido por assumir a responsabilidade da saúde mental de todo esse território, sem seleção para o diagnóstico ou gravidade. Isso quer dizer, que o CAPS é responsável, é o lugar para pessoas em crise, para aquelas pessoas que são ditas estabilizadas, para pessoas que talvez necessitem de programas de "presa in carico" momentâneo, ou seja, o CAPS, como lugar de "presa in carico" que eu vou traduzir assim, que eu acho que fica mais fácil, não precisa repetir sempre. Vou manter o italiano, "presa in carico" como toda demanda de saúde mental de um território. Nesse sentido o CAPS deve ser o lugar, inclusive "presa in carico" ser traduzido por assumir a questão do cuidado, mas retomando, enfatizando, aqui "presa in carico" traduzido como assumir a responsabilidade, eu acho que é uma coisa bastante conhecida de diversas pessoas, se não for, depois nós podemos retomar.

Não podemos, também, fazer essa tradução em termos do cuidado porque quero falar da tomada de responsabilidade global em relação à pessoa, não apenas naquilo que se refere ao que poderia ser pensado com a sua doença, mas as suas necessidades complexas também compõem o seu sofrimento. "Presa in carico" global, construindo projetos individuais que partam da unicidade daquela geografia, daquela trajetória de vida, naquele contexto e das modalidades de como se expressam o sofrimento daquela pessoa. "Presa in carico" que coloca em campo recursos distintos, complexos, que dizem respeito, sim, às respostas médicas, psicológicas...Mas, sobretudo, aquelas relativas à vida global daquela pessoa.

Respostas para poder responder aqueles princípios aos quais o Saraceno fez referência e isso implica também a qualidade dessas respostas do ponto de vista técnico, mas evidentemente as repostas ao que se referem ao acesso à cidadania. Nos projetos individuais de "presa in carico", nos projetos individuais de cuidado, nós ativamos recursos e quais são os recursos que nós podemos ativar. Eu partirei de recursos, em primeiro lugar, daqueles que geralmente são poucos valorizados, que são exatamente os recursos daquela pessoa que nós estamos assumindo ao "presa in carico" daquela pessoa que veio em busca de alguma forma de ajuda, mesmo que sejam recursos residuais, mas o fundamental é de que são recursos a serem valorizados daquela pessoa, de onde se pode partir o seu processo de retomada. E também os recursos da família e do contexto daquela pessoa. Saindo pelo menos, buscando sair das respostas assistenciais e favorecendo o protagonismo das pessoas, inclusive das pessoas quando elas estão em crise.

Em seguida, ativar recursos de cada serviço, de cada CAPS. E também ativar os recursos do próprio CAPS, estou falando aqui das coisas mais cotidianas, das possibilidades do dia a dia no CAPS, da refeição, das atividades culturais que o CAPS promove 
e, sobretudo da relação com os trabalhadores e da relação em que os trabalhadores vão construindo nesse processo.

Evidentemente que os recursos de cada CAPS dependem dos contextos socioeconômicos dos quais os serviços estão inseridos, mas na nossa história de serviços de Trieste, que certamente tem recursos diferenciados, mas não são recursos que vieram do alto, foram recursos que foram conquistados no processo de Desinstitucionalização, dessa passagem do hospital, organização dos serviços e, portanto, da reconversão de recursos do hospital aos serviços no território. Eu considero importante enfatizar isso, porque na minha experiência tanto na Itália, como em outros lugares muitas vezes as pessoas dizem, "mas, vocês em Trieste têm recursos". Sim, mas são recursos que foram recompartidos, dessa reconversão de recursos no processo de Desinstitucionalização e muitas vezes faltam no serviço, ou porque os serviços não ativaram esses processos, não os atravessaram ou os atravessaram de uma forma burocrática. Desculpe, nós temos um problema aqui que estão dizendo do tempo, mas eu gostaria de colocar que o meu tempo está sempre dividido, porque no meu tempo tem a tradução, então eu queria perguntar se eu posso ter mais tempo, claro que eu posso parar a hora que vocês acharem que eu devo parar (aplausos). De qualquer forma eu sinto muito em não falar português, certamente seria muito bom. Bom, mas continuando, nós temos também que ativar recursos de outros serviços na comunidade, desses outros serviços que estão presentes, para compor essa "presa in carico" global da pessoa. O CAPS deve ser também um lugar de contraste de fragmentação de respostas, isto é, para cada pessoa deve ser o lugar que coordena esse percurso de cuidado, que mantém essa referência, podemos dizer assim, sem encaminhar a outros serviços e sem também colocar para a pessoa a responsabilidade de que ela faça esse percurso de cuidado nos outros serviços.

Uma outra questão que eu considero fundamental é que o CAPS seja esse lugar que possa operar a garantia do direito de asilo. Garantia de direito ao asilo, aquela que o manicômio daquela forma oferecia paradoxalmente, mas o Capes deve ser esse lugar de poder garantir direito de asilo, sem evidentemente trocar a proteção, esse momento de cuidado, pela abolição de direitos que é como era feito no manicômio. Nesse sentido, a presença das camas para garantir o direito de asilo e, também, para aquelas situações conflitivas, nas quais as pessoas precisam momentaneamente estar um pouco mais distantes dos seus contextos de vida. Por exemplo, porque não tem momentaneamente na sua vida, naquele seu contexto, por exemplo, uma casa. Mas também aquelas camas para poder ficarem as pessoas quando elas estão em crise, responder a essas situações, mas sem interromper as relações familiares e sociais, sem reproduzir os mecanismos 
hospitalares e possibilitando que a pessoa possa viver a crise no interior desse contexto não hospitalar e que possa ser o mais próximo possível de um contexto da vida cotidiana. E também, que eu esqueci no final, no interior de relações múltiplas. Porque o centro de saúde mental, deve ser também um lugar atravessado pela comunidade, não um lugar que tenha somente a presença de profissionais, porque isso permite a crise ser reduzida no tempo, permite que isso possa ter um tempo menor desse processo de crise. Mas o CAPS também deve ser capaz de fornecer apoio a algumas pessoas que necessitam disso em relação aos seus problemas de vida. Por isso a questão das refeições, dos armários, dos momentos de encontro e de sociabilidade que possam também contemplar a dureza da solidão. Mas, também, pode ser um lugar de reaquisição de habilidades da vida cotidiana, mas não evidentemente em atividades de entretenimento como se disse anteriormente, mas na inscrição dessa pessoa na vida cotidiana do serviço, podendo, inclusive, ter responsabilidades pequenas até, mas responsabilidades no sentido que ela se sinta pertencendo a essa vida cotidiana.

O CAPS é um lugar muito importante de interações e trocas...profissionais, humanas e sociais. E é nesse processo de interação, de confronto de trocas, que se pode concretizar a redistribuição do poder e, para nós, isso foi no processo de Desinstitucinalização. Quer dizer, ao contrário, a distribuição do poder se coloca como uma estratégia fundamental na Desinstitucionalização, uma rede de distribuição de poder entre os profissionais, os usuários, os familiares, e os papeis profissionais. Através dessa sintética descrição de um centro de saúde mental e pensando no CAPS, eu poderia trazer aqui em uma imagem, em termos de porque eu falei que o CAPS vem sendo atravessado o tempo inteiro pela comunidade, mas eu gostaria também de representar aqui o centro de saúde mental, uma outra definição de Rotelli, que é a definição do centro de saúde mental com o mercado de Marrakech, o lugar de encontro. O lugar de encontro entre saúde e doença, entre pessoas de diferentes classes sociais, com distintos problemas de saúde e que nesse processo de encontros de trocas e de confusão é que se pode produzir saúde mental. E dessa forma então, mercado de Marrakech é também lugar vazio, mas lugar vazio no sentido de descentramento para a comunidade como bem disse Benedetto. Nesse sentido, portanto, contemporaneamente, nós devemos fazer um exercício de esforço contínuo desse descentramento e de todas as coisas que foram ditas antes, que não é possível em termos de tempo de retomar, em direção à comunidade. Em particular, a "presa in carico" da pessoa que está sofrendo no seu contexto de vida, no local onde ela vive, por exemplo, na sua moradia, nesse contexto, que de alguma forma, é o que determina esse processo. $\mathrm{O}$ acompanhamento das pessoas para o acesso aos direitos de cidadania e, sobretudo, ao exercício dos direitos e de cidadania. Isto é, o 
apoio às pessoas na concretude a sua vida cotidiana. E com isso concluo que o cuidado de uma pessoa não pode ser se não intervenções, no sentido de transformar as formas, as modalidades que esse sofrimento se expressa e também a sua intensidade desse sofrimento, mas contemporaneamente, mudar as condições concretas de vida.

Obrigada.

\section{Prof. ${ }^{a}$ Dr. ${ }^{a}$ Sônia Barros}

Enfermeira, Professora Titular do Departamento de Enfermagem Materno-Infantil e Psiquiátrica da Escola de Enfermagem da USP.

Quando houve a formulação e a proposição desse tema na programação deste evento, eu pensei que poderia contribuir por meio da exposição de uma face do nosso trabalho docente, pois nos últimos 30 anos o que eu tenho feito profissionalmente é sempre partindo da condição de professor, assim uma das faces do nosso trabalho que eu vou trazer para apresentar nesta mesa, até como uma forma de coletivizar um tema que muitas vezes é chamado pejorativamente de trabalho acadêmico. "ah esses estudos, trabalho acadêmico". Quando na verdade, muitos de nós que estamos aqui somos, sempre, os atores principais desses estudos: trabalhadores, usuários, familiares, alunos, professores. Estamos sempre, de alguma forma, sendo os sujeitos ativos de estudos e que, muitas vezes, nunca veem o retorno dessas pesquisas. Então preparei uns slides e vim aqui na maior disposição, só não contava que ia ter que falar depois do Benedetto e da Giovana, isso não é uma tarefa fácil, principalmente ao meio-dia e meia, então vou tentar ser objetiva. Os slides estão com muitas informações, mas a ideia era essa mesma, de passar mais informações objetivamente, considerando o pouco tempo que a gente dispõe.

Eu vou falar sobre uma coletânea de trabalhos realizados pelo grupo de pesquisa Enfermagem e Política e Práticas de Saúde Mental. Esse grupo de pesquisa, que iniciou suas atividades no início dos anos 2000 tem desenvolvido, como o próprio nome diz, estudos sobre as políticas de saúde mental no Brasil e suas implicações nas práticas e no ensino na área de saúde, claro que especialmente na área de enfermagem. Nós trabalhamos com duas linhas de pesquisa, uma que é Políticas e Práticas de Saúde Mental e Enfermagem e Enfermagem enquanto Prática Social. O grupo é interdisciplinar, na sua história de 15 anos, um pouco mais, ele tem sido composto por diversos profissionais da área de saúde e atualmente nós temos 16 membros no grupo, entre eles pós-doc, 
doutorandos, profissionais do serviço, profissionais que estão pensando em fazer um programa de pós-graduação.

Qual o interesse que o tema desta Mesa, Inclusão e exclusão, desperta para esse grupo? É quase que uma lógica.... Os diversos documentos e normativas que se referem à política de saúde mental no Brasil todos eles falama sobe o tema de inclusão e exclusão social. Em algum momento ele é finalidade do próprio CAPS, em outros é compreendido como as estratégias de desinstitucionalização que passam por ações de inclusão, os dispositivos existentes para isso, inclusive, como a residência terapêutica, são dispositivos de inclusão social e até mesmo a RAPS, na sua descrição fala que uma de suas finalidades é inclusão social. Então, se o grupo tem estudado, ao longo desses 15, 16 anos, políticas de saúde mental, é quase que consequência natural que dentro desses estudos apareçam as questões de inclusão e exclusão social, ou como objeto de estudo, ou enfim nos seus resultados, nos seus descritores. Então, o grupo tem trabalhado com essa definição de exclusão e inclusão social entendendo que esse é um processo multidimensional, que o termo é frequentemente usado como consequência de privação material e restrição de oportunidades, mas entendemos que o processo de inclusão social também acontece em diferentes esferas da vida, como o trabalho, o lazer, ter amigos, não ter amigos, família, residência etc. Eu estou falando rápido, mas é que a vida é assim, não é gente? Então vamoslá.

Bom, então é isso que eu tinha acabado de falar para vocês, esse interesse enfim que o grupo de pesquisa tem pelo tema, decorrente das suas próprias linhas de pesquisa, dos estudos que vem desenvolvendo, a categoria de inclusão e exclusão social acaba aparecendo como objeto, como categoria de análise e seus resultados. Com essa perspectiva, vendo essa produção dentro do grupo de pesquisa (GP), alguns membros do GP resolveram fazer um levantamento de que estudos são esses. O que estão dizendo esses diversos estudos que o grupo produz e que estão em forma de pesquisa, dissertação, tese, artigos publicados. Resolveu-se então fazer uma revisão integrativa, na perspectiva de que pudesse trazer aqui alguns resultados dessas pesquisas, desses estudos. A revisão integrativa justificou-se porque ao compilar os estudos que são relacionados à temática de inclusão e exclusão social, pode-se gerar um documento que facilite aos acadêmicos, gestores e trabalhadores em saúde e público em geral o entendimento e o acesso a essas produções. Até porque nós vivemos essa história de que as teses, as dissertações são realizadas, depois vão para a biblioteca e ninguém nunca mais vê. Então, com essa revisão é possível responder uma questão central, que é como se compreendem as ações de inclusão nos serviços territoriais no município de São Paulo. Não é a perspectiva, aqui, de 
trazer check list de ações que devem ser feitas ou podem ser feitas. A ideia é compreender como esse processo tem se dado nos CAPS aqui em São Paulo. E uma outra justificativa é que apresentar estes resultados, mesmo que parciais, pois ainda está em processo de análise, então apresentar este estudo neste evento é uma oportunidade única de poder fazer uma devolutiva aos sujeitos que estão de alguma forma envolvidos nestas questões durante todo esse período.

Então qual foi o objetivo desse grupo ao fazer a revisão integrativa? Era identificar o conceito de inclusão social, que está definido nos estudos selecionados. Geralmente, o pesquisador ao desenvolver um estudo tem uma concepção anterior. Então um dos objetivos era identificar quais são esses conceitos que os pesquisadores têm usado ao fazer pesquisas, estudos ou reflexões sobre esse tema. Outro, foi o de Compreender o processo de inclusão e exclusão social na perspectiva dos usuários de serviço de saúde mental, de seus familiares e dos profissionais desse serviço relatados nos estudos analisados. $\mathrm{E}$ ainda desvelar os avanços e desafios para a inclusão social apresentados nos resultados desses estudos. Para atingir esse objetivo foi realizada uma revisão integrativa, como dito anteriormente. Assim, foi feita uma revisão de todos os produtos do grupo de pesquisa que tinham a inclusão e exclusão social como objeto de estudo ou em seus resultados. A revisão de literatura tem uma definição, que é esse processo pelo qualse busca analisar e descrever um corpo de conhecimentos. E a revisão integrativa tem como missão revisar, criticar e sintetizar de modo integrado a literatura representativa de um tema, gerando novas abordagens. Então, a gente espera que ao finalizar este estudo da revisão integrativa possamos gerar novas questões para outros estudos inclusive.

Sobre os procedimentos, foi feito todo um levantamento do que se tem publicado, tudo o que se tinha de dissertação, tese, do coordenador do grupo com os outros membros do grupo nesse período através da revisão do currículo Lattes, foi feita uma leitura de títulos e dos resumos dos estudos que estavam incluídos na plataforma e no caso em que os títulos ou resumos não fossem claros o suficiente, buscou- se a leitura desses trabalhos. $\mathrm{Na}$ primeira fase foram selecionados 128 estudos, compreendendo capítulos de livros, teses, dissertações, monografias, artigos científicos, projetos. E o melhor é que tem muitos autores hoje aqui, desses estudos, tem bastante gente aqui que são autores. Da leitura desses 128 artigos, na íntegra, pôde-se buscar o que eles traziam de descritores: inclusão, exclusão, cidadania, estigma, discriminação. Nessa fase, que foi ler e buscar esses descritores, foram retirados os que não tinham os descritores definidos, passando então para 104 textos. Desses textos procurou-se ver o que eram resumos, que foram apresentados em eventos, mas que na verdade já eram um subproduto de outras publicações. Se esses 
resultados já apreciam em alguma outra publicação, foram excluídos então, restando 46 trabalhos. Depois que as alunas a Anaísa, a Jussara, a Lara e a Laís já tinham feito essa computação, foi publicado mais um artigo da Mariana e então esse universo de trabalhos que a gente começou a trabalhar, ainda não finalizou, foram 47. Foi realizado, todo um procedimento de organização desses textos, foi criado um formulário, uma ferramenta do Google, esse instrumento, a partir das questões que são indicadas ele gera produtos, gráficos, tabelas o que facilitam uma certa leitura quantitativa do que foi apresentado. E depois, a partir dos dados gerados, por esse formulário elaborado no Google, foi possível selecionar os resultados que respondem aos objetivos desse estudo. Foi possível, então, identificar em quais cenários esses 47 estudos foram realizados e eles foram realizados em quase todos CAPS do município de São Paulo, CAPS adulto, em quase todos porque, no desenvolvimento da pesquisa, tem sempre um serviço que diz "ah, agora não dá, deixa para amanhã, volta depois", e "não, a equipe está muito atrapalhada” e raramente a gente consegue completar a totalidade dos CAPS escolhidos. A maioria, mais isso é assim, é um, dois, porque de fato, a maioria dos CAPS adultos foram cenários, um CAPS em Campinas e as unidades básicas de saúde da região oeste do município de São Paulo, portanto os estudos neste caso foram realizados nesses serviços.

Quem são os sujeitos participantes daquelas pesquisas? Nós temos usuários, trabalhadores, usuários e familiares, usuários e trabalhadores. E ainda foi possível fazer uma caracterização do que esses estudos diziam, traziam, que tipo de pesquisa foi feita. Então, dos estudos que o grupo desenvolveu até agora, 67,4\% são estudos qualitativos. Então, tem estudos quantitativos, estudos de revisão de literatura, mas massivamente, a maioria dos estudos que temos desenvolvido no grupo de pesquisa são qualitativos. Assim, dos 47, na verdade, o número deve ser 48 com o mais recente publicado, 29 são artigos científicos indexados em base nacional, 3 são artigos científicos indexados em base internacional, 2 em anais de evento nacional, são 8 teses de doutorado e 6 dissertações de mestrado. Então, nós temos artigos, em sua grande maioria, livros, dissertações e teses.

A tendência das dissertações e teses é virar em artigos, agora tem pós-graduando que esquece, desaparece, mas uma grande maioria publica os seus resultados, porque é do interesse de que se conheça o trabalho desenvolvido. Temos também uma caracterização dos estudos que foram incluídos nessa revisão integrativa. São 47, e para ilustrar esta caracterização vamos ver dois artigos: um deles, intitulado Práticas de Inclusão Social, Desafio para o Serviço de Saúde Mental, tinha como objetivo compreender como ocorrem as práticas de inclusão social voltadas para os usuários dos CAPS, no intuito de contribuir para a avaliação do serviço e segue uma descrição breve da metodologia; 
um outro, que é sobre as Representações sociais de usuários de um Centro de atenção psicossocial e pessoas de sua rede, sobre a doença mental e inclusão social, também tem o objetivo de verificar e analisar as concepções expressas pelos entrevistados sobre inclusão social e doença mental, também um estudo qualitativo. Desses mesmos artigos podemos ver nos slides, uma síntese dos resultados que esses estudos apresentaram. No artigo de Práticas de Inclusão Social, um dos resultados das entrevistas com os profissionais de serviços aponta: profissionais que compreendem a inclusão social como um processo que abrange desde o direito de cidadania até o fato de ser aceito e participar efetivamente do contexto social, junto com essas várias pessoas. No outro trabalho, que era de representações sobre o conceito de inclusão, a análise dos resultados aponta que para os usuários entrevistados a participação no mercado de trabalho é um dos elementos centrais para a inclusão social; esta compreensão é reproduzida em outros artigos analisados pela revisão integrativa.

Ao fazer a análise de todos os resultados dos 47 estudos e ao submetê-la a uma análise temática, foi possível então ver 4 categorias empíricas emergem: o conceito de inclusão, o processo de inclusão na perspectiva de usuários, de trabalhadores e de familiares, a inclusão e exclusão social como é que se dá nos 3 eixos da reabilitação psicossocial, e por fim potencialidades e desafios da inclusão social. Verificou- se nos estudos analisados, que os conceitos de inclusão social que foram utilizados pelos pesquisadores estavam fundamentados em autores tais como Castel, Basaglia, que sustentavam a discussão da inclusão e exclusão; mas nos resultados foi possível também identificar o que os sujeitos participantes dos estudos compreendiam como inclusão e exclusão social; para usuários e familiares, dos diversos estudos: inclusão social é um processo que abrange o direito de cidadania, ser aceito no contexto social, ser diferenciado e inserção no mercado de trabalho. Dizem ainda que é preciso resgatar habilidades do viver cotidiano, mudando o comportamento rumo à normalidade, a fim de ser incluído socialmente. Esses resultados que estamos apresentando, ainda estão em análise, mas vamos percebendo as contradições que vão surgindo no discurso, tanto dos usuários quanto dos trabalhadores. Por vezes eles compreendem a inclusão e exclusão como algo muito próximo e que está definido dentro da política, entretanto, e por vezes, trazem a sua compreensão a partir do senso comum, a partir do pensamento hegemônico, por exemplo, tenho que retornar a normalidade.

Em todos os discursos vão aparecendo contradições, conflitos e, também, se aproximam muito dos princípios que o Benedetto falou, e do que a Giovana fala também, da compreensão de um serviço que faça inclusão. Então, a análise será muito interessante, 
porque vai emergir essas representações que se aproximam da política prescrita pela Reforma psiquiátrica, mas também as contradições existentes, quando surgem conceitos são baseados no senso comum de conceitos de normalidade, de conceitos de periculosidade... em todos os segmentos, inclusive dos trabalhadores. Para os profissionais também, inclusão significa ser aceito, acolhido, compreendido. Interessante como na fala de diversos usuários, de vários estudos, é possível captar que eles vão dizendo como eles vivem a questão do estigma e como isso é um fator de exclusão; a questão do estigma, do preconceito, como isso é vivido na vida cotidiana, no dia a dia e como isso provoca a exclusão social. E eles relatam que lidam com esses rótulos mantendo segredo sobre sua doença, então escondem que fazem tratamento, acho que vocês sabem disso, mas isso também tem um custo. Ao não revelar, não falar de si, de sua vida ao vizinho ou ao amigo, ele se isola socialmente. Isso é reconhecido pelo próprio usuário, eles falam disso. Eles têm uma expectativa, os usuários, de poder viver melhor, o que inclui constituir família, expandir e intensificar relacionamentos, trabalhar e não necessitar de internações como forma de tratamento. Essas são as expectativas de inclusão que eles têm.

As famílias, os familiares, na síntese das diversas falas dos familiares, as mães principalmente, as mulheres são na maioria as cuidadoras, elas relatam como são excluídas junto com os filhos. É um processo de exclusão que os filhos sofrem, o isolamento social, é levado também para os familiares. Ao mesmo tempo, referem como emprestam o seu poder contratual para o usuário, como vão buscar coisas, como vão negociar na comunidade em função do usuário. E também diz que os usuários têm rede social diminuída, esta é a avaliação dos familiares e deles também, familiares são segregados. Reiteram que cuidar do familiar impede ou dificulta a continuidade do trabalho dessa pessoa e isso, sair do trabalho, ficar sem emprego, ficar em casa é um fator de exclusão social. Mas também reconhecem que existe uma rede de vizinhos que possibilitam, conseguem fazer arranjos de forma a introduzir esse familiar no mercado de trabalho e que contam com a solidariedade dessas pessoas até mesmo para comprar alimentos, quando eles estão desempregados e dar uma base de sustentação para essa família. E por isso eles se sentem incluídos na comunidade quando eles conseguem manter essa rede, esses vizinhos.

Ressaltam a importância da política pública e isso aparece nos discursos do usuário, nos discursos dos familiares e nos discursos dos profissionais. A importância das políticas públicas de saúde para a promoção de inclusão social. Todos consideram a inserção no trabalho e aí assim, tem uma exigência que o melhor é o mercado formal, como um dos indicadores de inclusão social. Este é o indicador: se está trabalhando está incluído, se está fora do mercado está excluído. Concordam que o CAPS, ainda tenha que avançar 
em relação a ajudar o usuário a construir sua rede social fora das dependências do CAPS. E aí é aquela história, CAPS bom é CAPS vazio. Não é que não tenha usuário, mas que os usuários estão fora, estão na rede, estão por aí. Então todos reconhecem que existe essa dificuldade e que o usuário fica muito dependente da inclusão social que se dá dentro do serviço, mas evidenciam que o CAPS é um espaço de pertencimento e acolhimento que inegavelmente produz mudanças favoráveis à vida dos usuários. Eu acho bom a gente ouvir essas coisas legais de vez em quando. Ainda identificam ações de inclusão social voltadas ao território e no âmbito do acesso ao transporte, lazer, cultura, trabalho e educação bem como práticas de socialização de espaços.

Citam limite para as práticas de inclusão social, e esse discurso é predominantemente dos trabalhadores, por falta de recursos financeiros, falta de políticas sociais, existência de muita burocracia para receber auxílio financeiro, por desvalorização desses trabalhadores, desmerecimento da pessoa com transtorno mental em relação ao exercício do seu direito político. Dizem, ainda, que a ausência do familiar dificulta a inserção social e produtiva. Reconhecem a necessidade de ampliação e desenvolvimento de ações em torno de atendimentos aos usuários, intervenção com as famílias e das oficinas para a promoção da inclusão. Os profissionais entrevistados, por todos esses estudos, nesse período de tempo, avaliam que: os CAPS têm a função de promover a inclusão social, mas que na verdade o serviço ainda isola as pessoas, porque traz para dentro, então isola do que está fora; Que o CAPS não modifica a posição do excluído, apenas a atenua; Que o serviço é uma estratégia para impulsionar a inclusão, ao enfrentar a cultura estigmatizante, construir uma rede social, estimular a autonomia, evitar internações e possibilitar outras formas de tratamento, mas precisa de investimento.

Ainda, na avaliação dos trabalhadores, a avaliação do CAPS é necessária para que não haja reprodução da lógica manicomial. Esta é a avaliação dos trabalhadores. Tem mais, mas eu vou passar. A família tem quase que as mesmas concepções, falam da dificuldade, falam da questão da rede social como um fator de inclusão e exclusão e tem outras categorias, aquelas que eu falei para vocês. Então tem uma outra categoria que é como se dá o processo de inclusão do ponto de vista dos trabalhadores, dos usuários e dos familiares, mas como temos pouco tempo e já estamos com menos da metade de público, vamos chegar às conclusões. Então são conclusões dos estudos, não é conclusão dos autores dessa revisão, porque isso ainda está em elaboração. Uma súmula das conclusões que esses trabalhos apresentam indicam que a inclusão social das pessoas com transtornos mentais implica no exercício de sua cidadania e de sua inserção no mercado de trabalho. Apesar do trabalho ter importância como uma ferramenta para a 
inclusão, não é vislumbrado como uma meta próxima, ou que esteja ao alcance das ações dos profissionais de saúde. Então tem um número relevante de trabalhadores que dizem assim, “o que eu posso fazer com isso?" Ou ainda alguns que dizem que “isso não é minha função". E ainda muitos consideram-se impotentes em promover ações nesse sentido, impotentes é dizer, "mas não temos recursos, não temos isso, não temos aquilo", ainda que digam que essa dificuldade se torna maior porque as ações de inclusão terminam sendo limitadas ao meio institucional. Enfim, dizem que nesse contexto, o projeto institucional que sustenta as ações do CAPS deve apresentar clareza em suas diretrizes e que na maioria das vezes o projeto institucional não define, não é claro como fazer isso. Apesar de estar no discurso, se a gente buscar as informações institucionais, a primeira coisa que os gerentes dizem é que de acordo com a política a missão do CAPS é fazer a inclusão social, mas se, se olha o projeto, não está dito quais são as estratégias, como fazer e o que fazer. Bom, gente, obrigada. De outra vez a gente conversa mais, vamos tentar desmistificar essa coisa de que a pesquisa não nos serve. Acho que pode dar bons indicativos, bons caminhos. 


\section{Palestra - Direitos e cidadania dos usuários de álcool e outras drogas}

Coordenação: Profa . Dra. Paula Hayasi Pinho - Psicóloga, Pós-doutoranda na da Escola de Enfermagem da USP.

\section{Dr. Antônio Lancetti}

Psicanalista, Consultor do Programa de Saúde Mental de São Bernardo do Campo, Ex-Secretário de Ação Comunitária no município de Santos, Ex-consultor do Ministério da Saúde para o Plano Crack.

(Cumprimenta os organizadores, amigos e plateia)

Então esse sujeito sem direitos, que depois escreveu outro livro chamado Homo Sacer, era aquele sobre o qual se poderia fazer qualquer coisa, por que aquele sujeito não tinha desejo, não tinha palavra, muito menos direitos, o livro se chama "O que sobrou de Auschwitz" e depois escreveu isso que nós usamos hoje tão coerentemente que é a história das “ilhas de exceção", Então, eu fui supervisor das equipes de saúde da família desde 2009, aqui na cracolândia paulistana e todo tipo de abuso foi cometido com essas pessoas, desde PMs apostando, com estilingue, quem acertava mais nóias, com bolinhas de gude, internações involuntárias, programas que definem (tenho um colega que diz assim, ele tem um livro chamado O Usuário de Crack, vocês já viram a capa, ele é quase assim, para bom entendedor meia palavra basta, e ele diz que o cara que o uso continuo de crack é uma doença crônica, recidivante que nãoprecisa do consentimento do paciente para ser tratado).

Bom, com esse critério se criou o Programa Recomeço, primeiro estabiliza, depois interna para sociabilizar e fica curado, se bem que eles conseguiram convencer muitos agentes comunitários, mas eles depois vieram assim desanimados por que quase todos eles voltaram para a zona de uso, quando não para as cadeias, então, como para nós o problema da cidadania tem sido essencial? O Guattari disse que o Basaglia, ele elevou ao status ontológico o conceito de cidadania, o que significa isso? Que quando você bate o 
olho no paciente, você fala, "esse sujeito, primeiro, é um cidadão" e depois, "é um paranoico, é um dependente químico ou uma histérica". Então, nós fizemos uma das maiores reformas psiquiátricas, porque aqui se comemoram quinze anos, no mundo, baseada no conceito de cidadania que se traduz assim: "Por uma utopia de uma sociedade sem manicômios".

Utopia mais ou menos, por que em Santos, (eu tenho colegas aqui a Sandra Chioro, que? E ainda eu e Andrea, que foram protagonistas, não sei se tem mais gente, e que não foi uma utopia. Lá, nós transformamos uma cidade média, pequena-média, numa sociedade sem manicômio. Santos foi a primeira cidade brasileira sem manicômios. $\mathrm{O}$ Guattari falou (Andrea é testemunha, foi uma boa conversa), que lá aconteceu a quarta revolução psiquiátrica, não é verdade? Então, nós estávamos indo bem. Vivendo em um Brasil amoroso, fazendo grupos, festas, até que nos lançaram a campanha da Epidemia do Crack e, nós que já sabíamos tratar de esquizofrênicos, e não foi nada fácil, nos pegaram de calças curtas. E muita gente se atrapalhou e nós tentamos muitas coisas. Eu participei do Plano Crack, com a capacitação da polícia comunitária, eu acho que o Plano Crack, que do ponto de vista midiático foi ruim, ele funcionou. O plano crack foi acompanhado de uma extensão da rede de cuidados, porque o Tykanori e o Leon quando estavam no Ministério eles falavam: "a gente não pode matar o crack, nem

o craqueiro, mas a gente pode oferecer uma rede de cuidado". E essa rede foi criada e não foi nada fácil, primeiro, porque (escrevi um livro chamado "Contrafissura" com um problema maior, que tem cada técnico que atende usuários de drogas e quer salvá-los e acham que uma pessoa pode ficar em abstinência, ou acha que pode atender também da mesma maneira como atendem os outros. E... então, muitos CAPS álcool e drogas põem agendas, não atendem as prioridades. Aqui que eu posso falar entre amigos, certo? Agora, o Denis é testemunha que lá em Guarulhos, uma administração progressista tinha muitos problemas para atender drogados.

Enfim, então, além desses problemas, que acho que todo mundo padeceu, eu quando descobri o primeiro menino usuário de crack, em Santos, peguei ele, com o meu carro, e fui para a praça da Independência peguei ele no braço e levei para o pronto socorro. E não perguntei se ele queria ou não queria e ele, "não quero". "Você não é minha mãe para me levar" e eu, "não sou sua mãe, não sou seu pai". Então, nós fomos (lembro que o livro, que a gente escreveu nos últimos dias de governo em Santos se chamava Assistência Social e Cidadania e o capítulo sobre os usuários - porque chegou o crack em Santos e de uma hora para outra e tudo mudou - então, o capítulo se chamava "Crack: endurecer sem perder a ternura”. Fizemos de passagem, a nossa pequena homenagem ao 
comandante. Então, nós temos criado redes, incluindo pessoas das UBS, mobilizando... o grande exemplo é em São Bernardo, tem alguém de São Bernardo? Só você? O dia que se faça a história da saúde mental brasileira e do trabalho com usuários de drogas, vão ter que pendurar um quadrinho com a foto do CAPS Ad de São Bernardo do Campo, e o CAPS Ad também, que passou muitos perrengues mas, porque foram precursores do que é trabalhar em rede, porque foram precursores do que é se superar a cada momento, porque não é qualquer sujeito que consegue tratar de usuários que são verdadeiros toxicômanos, miseráveis, pessoas com longas vidas passadas nas cadeias e nas clínicas de recuperação. Então, nós temos feito esse esforço, não temos avançado muito, sabemos que agora está em um momento muito difícil, e eu acho que o grande destaque que devemos fazer é o programa De Braços Abertos.

O Programa de Braços Abertos, eu não sei se aqui foi comentado ou vocês o conhecem, mas ele tem uma ideia inicial, junta com algumas ideias iniciais, a primeira é que ele foi inspirado em um programa americano e é justo aqui fazer (porque a gente falava assim "o que vamos fazer de diferente? PSF tem. Mal. Porque funcionava muito mal aqui, porque achavam que PACS de rua era a mesma coisa que consultório na rua. Nós temos serviços de saúde que de alguma maneira funcionam com alguma conexão, porque durante esses dois anos anteriores cada um chutava para um lado, e os agentes comunitários quando levavam um paciente ao Pronto Socorro eram humilhados junto com os pacientes, e a assistente social trabalhando empurrando pessoas, e a guarda municipal jogavam gás de pimenta por uma lei aprovada na Câmara dos Vereadores desta cidade aqui pertinho, e apoiado por $90 \%$ da população paulistana. E, o Tykanori ligou para o Saraceno e o Saraceno disse, "olha, a única coisa nova que tem é housing first". Housing first é uma invenção americana que depois se aperfeiçoou no Canadá e em outros lugares, que consiste em dar primeiro casa, porque o psicólogo Sam Tsemberis, que parece que foi o primeiro que começou a pensar nisso, se cansou de levar a pessoa para as comunidades terapêuticas e a clínicas de recuperação e as prisões, levavam para lá e perguntavam, "quem é que está falando"? Voltavam para a zona de uso e para o mesmo buraco, ele teve essa ideia, só que nem ele mesmo acreditava na ideia, e um ano depois ele verificou que $84 \%$ das pessoas ainda estavam nos hotéis, claro que não é nada fácil. Aqui que tem uma profissional que coordena os hotéis aqui da região e sabe que é um turbilhão, mas está escrevendo sobre essa loucura, o capítulo sobre o Braços Abertos, deveria se chamar "hotéis dos braços abertos: os turbilhões". E, foi bom, uma longa discussão, com muita paciência, porque, engraçado, porque nem o projeto Qualis quando a gente inventou, de Saúde Mental com a equipe volante sem CAPS e sem ambulatório, a gente sofreu ataque de todos os lugares, a começaram pela direita e logo após, pela esquerda. 
O Davi, me lembro uma vez que foi convidado para falar aqui, na Câmara, e falei que se não fosse um amigo, eu achava que aquilo era uma armadilha, porque me bateram tanto, quando fui explicar como funcionava, que os agentes de saúde e os enfermeiros e os médicos iam para a casa da pessoa. O único que nos apoiou foi... alguns loucos como sempre e o professor Adib Jatene, porque quando eu contei para ele, o que fazíamos, ele disse "olha Lancetti, tenho cinquenta anos de experiência clínica, o que um médico sabe em seu consultório se comparado a uma visita domiciliar?". Então aquilo lá, nem é nosso companheiro, mas com o Braços Abertos aconteceu isso. As pessoas nas reuniões, quem coordenava as reuniões era o Sottili, que era secretário de direitos humanos, ia lá para criticar que não tinha dados, que a guarda municipal era pior que a PM, mas nós acabamos de criar uma inspetoria especial para redução de danos para a guarda municipal, nós capacitamos esses guardas para serem intermediadores, as pessoas nos hotéis bancam as crises que eles tem, porque nós ainda somos de uma geração ou de várias gerações que acreditamos que uma pessoa pode mudar.

Então, o Programa de Braços Abertos, realmente, depois de todas essas discussões, lançou, foi muito interessante, o Programa de Braços Abertos começou dia 14 de janeiro de 2014... 2013... 2014, na reunião (eu vou ter que sair correndo daqui, porque essa foi à primeira, agora, vai ter a última reunião (eu deveria estar às três lá, eu vou chegar atrasado, eu já cheguei aqui, vocês também estavam). A gente lançou no dia 14, na reunião com o prefeito estava tudo pronto para lançar no dia 15 e ai, eu falei uma coisa que não vou repetir aqui que não vai dar tempo, mas é, eu falei "prefeito, não pode ser no dia 15" (que a gente aprende, efetivamente, aprendemos em Santos o fator surpresa)... dia 13... 15 não pode ser, por que dia 15 vão entrar os holofotes, vão estar um monte de mídias lá, nós temos que falar um dia e fazer outro e foi fantástico, por que no dia anterior já estavam conversando, o pessoal do consultório na rua, que ainda não era, mas já se chamavam e as assistentes sociais, e ai quando explicaram que eles iriam negociar... Tudo bem compadre?(Cumprimenta Paulo Amarante, que entra no auditório) - Ele vem acompanhado de um grande antropólogo. E ai, porque havia uma favela na Rua Silva Bueno, e os holofotes, as fotos, a mídia inteira falando da favela, agora não tem favela, agora terminou, mas tinha a favela e tal, então foi negociado que se eles levantaram a favela... E ai, ele falou, eu montei meu barraco, eu vou desmontar, e ai começou a desmontar, nem todos foram desmontados por ele, mas a iniciativa foi deles, e foi assim como foi feita a primeira reintegração de posse no centro da cidade de São Paulo, sem bombas de gás lacrimogêneo, sem pauladas, com esse grupo de pessoas que são as piores, piores no sentido de "cidadania consiste em tomar o direito mais difícil, é o mais complicado". 
Muito bem, e assim foi como começou o programa De Braços Abertos dando o que nós chamávamos de "um pacote de direitos": dormir, comer e trabalhar. E, nós estivemos, (eu vejo isso nas suposições) sem o ânimo de... nós adotamos o conceito da redução de danos, mas nós tivemos que reinventar o conceito da redução de danos, porque a redução de danos como feita em São Bernardo ou em Aracaju ou em Recife, é diferente de como é feita aqui. Aqui, o grau de tensão que tem com os traficantes, com a polícia, com os tráficos diversos, e toda hora vira o problema, quando parece que a coisa está se arranjando a polícia prende o chefe do tráfico de chamado "disciplina" e fica sem chefe e ai vira uma balburdia e o consultório na rua não consegue chegar lá. Esse é um dos problemas, outro é a visibilidade, que tem os projetos, tanto é que apesar da Folha de São Paulo verificar que 69\% dos paulistanos apoiam o projeto De braços abertos, o candidato ganhador se elegeu com a ideia de que os braços estão abertos para... a morte e tudo isso, porque, claro, isso dá medo, todo sujeito tem medo.

Eu sou psicanalista e não conheço um paciente que não tenha a fantasia de dormir embaixo da ponte, inclusive o mais rico. O medo de ser tocado por um sujeito estranho, sujo e ainda que tenha a coisa fascinante de usar uma droga, que se você usar uma vez, não consegue parar mais. Então, é aquela mistura, senão, não teria tantos religiosos, tantos antropólogos, tantos, enfim, pessoas de todos os tipos querendo resgatar, enfim, eu acho que merece esse trato especial porque com o decorrer do tempo nós... primeiro, outra característica do programa é que ele é intersecretarial, ele não é de uma secretaria, ele não exige, seria o ânimo de insultar nossos ânimos. Nós devemos reinventar-nos. Não só pela violência, porque, bom, a primeira coisa que aprendemos, isso tanto aqui como no CAPS, que trabalha de portas abertas de verdade, é.... a baixa exigência, que muita gente entende por não fazer nada, ou deixar que a coisa corra solta, ela é acompanhada de uma altíssima exigência do operador, do cuidador. Perguntem as pessoas que trabalham nos hotéis ou favelas, vão ver como não é fácil permanecer lá, ou quem está na rua há muitos anos, né, como a companheira. Mas, enfim, altíssima exigência, quanto mais exigência significa baixo limiar de acesso, lá o trecho que significa baixo limiar de acesso e disparo, ou seja, o cara não precisa estar abstinente para participar, mas você injeta algumas drogas pesadas nele, por exemplo, o sujeito dorme, como eles falam, "com os dois olhos".

Nós fizemos um ato no Tuca, na terça-feira, e eu como tive um problema de saúde e faz tempo que não vou na cracolândia por problema de imunidade, perguntei para vários usuários “e, eu já sei que você dorme com os dois olhos, mas você sonha?", vai ele e fala, "muito mais". Mas o pior foi o Zé de Abreu, que é o nosso mentor, eu falei, 
“Zé, quando você estava na rua, você sonhava mais ou você sonhava menos?". Ele falou, "não, quando eu estava na rua eu sonhava muitos sonhos, agora é que eu sonho menos". "Como assim?". "Eu tenho sonhos repetitivos" (eu achei que eram sonhos traumáticos)," eu só sonho em como fazer para que essas pessoas saiam daqui, eu só sonho projeto de vida, meu e dos outros". Então, eu queria lembrar que o prefeito Doria, que ainda não é prefeito (é futuro), vai tirar o nome: De braços abertos. E nós como fomos derrotados, vamos ter que aguentar. Mas, será o quê? Porque esse nome foi tirado pelos usuários, com muita paciência democrática que cada vez que chamava para a assembleia, a polícia ficava na porta do ponto de apoio lá chamado Tenda, então, os usuários não queriam ir, lógico, foram ganhando confiança, foram discutindo o projeto, faz parte da metodologia do trabalho (não é que vai deixar para que eles resolvam tudo, que a gente também não é trouxa, certo?). Tem que ter comando, tem que ter escuta, então, quando tirem o nome De Braços Abertos, vão tirando um pedaço da alma do projeto. Eles já estão falando que, estão duvidando, que os hotéis vão fechar, por que? Porque estão vendo os resultados. Mais de 70\% excluída... coisa é difícil, vai dar um antibiótico ou atividade, para depressão geral dos trabalhadores de saúde.

Quanto trabalho eu tive? Que porcentagem? Mais de 70\%, e ainda de lambuja as pessoas consomem muito menos drogas, se você tem que acordar de manhã consome menos drogas que quando você não tem que acordar de manhã, e também por que se você dorme (parece tão evidente) que para tirar um cara da rua precisa dar uma casa e no entanto, aquilo que ficou uma espécie de revolução coopernicana ... hoje se uma pessoa rouba se fala, "não ele não rouba, ele tem que ir para o abrigo, ele pega cadeia", você não imagina que ele teria que ir para uma casa, embora seja uma coisa mais básica. Então, esses conceitos foram levados e isso trouxe muitos benefícios para a rede de Saúde Mental eu trabalhei em rede, tem pessoas aqui do CAPS que tiveram que quebrar a cabeça com esses casos mais complicados, ele obrigou a pessoa a sair da casinha, cada um de sua secretaria e produziu muitas surpresas, a gente não esperava que houvesse essa redução de consumo, a gente não esperava que muitas pessoas já nas primeiras semanas saíssem do local, isso ai eu chamei de segundo disparo, pois o primeiro disparo é essa condição: Caps que não funciona, você dorme em uma cama recolhido ou com medo que te joguem em um local deprimente. Aqui no CAPS do Bom Retiro de vez em quando aparecia paciente na AMA, especialmente negros e gays, com marcas da cruz suástica. Vocês fazem “ahhhh”, mas o médico achava normal, porque se o cara foi lá dormir no Baixo Augusta onde tem os carecas, e ele ainda é gay e preto... Então, olha só, o Saraceno na conferência que fez no Tuca, ele falou que esse passo, se começar com o direito, esse passo em vez de pedir para o cara parar de usar ou fazer xixi uma vez por semana 
no vidro, era uma forma de outorgar a cidadania. Não é que essa cidadania parou, por exemplo, hoje, a maioria dos usuários tem documentos. Olgaria Mattos me ensinou assim, que cidadania se entende assim, quando o PM te para e fala assim, "cidadão, você tem documento?". Então, não é só pelo documento, eu acho que essa é uma das maneiras de outorgar cidadania, de produzir, por que a gente não dá, a gente produz.

Bom, eu acho que nós temos um campo muito complexo no mundo, você recebe notícias de todo tipo, tem estados americanos que liberam o uso recreativo da maconha, está comprovado, está comprovado que tudo isso é muito mais caro, manter a pessoa pressa é muito mais caro muito mais ineficiente, então nós vamos sair daqui defendendo a eficácia desse projeto, mas veja, não depende de ideologia, depende da inteligência, por que se vocês vão querer fazer o que já fizeram, fazer procissões na madrugada de nóias, prendê-los, obrigá-los a se internar por que se não o cara vai preso, vocês vão fracassar, então nós deixamos um presente para a cidade, não sei se é um presente, mas deixamos um valor para a cidade, nós deixamos uma possibilidade de continuidade para os próximos gestores e vamos defender a sua continuidade. Mas nesse momento de tanta hipocrisia, de tanto, de algum modo falando de corporativismo. Bom, eu já tenho problemas de saúde, eu tenho uma certa facilidade para vomitar, não me custou muito, bom, mas enfim, nesses momentos, eu acho que nós perdemos muitas eleições e o pior é que nos roubaram os sonhos. Muitos ficaram culpados, principalmente os petistas, que ficam na dúvida, de dizer se roubou ou não roubou, é simples, eu acho que agora, no nosso coração antimanicomial, lhes dizer, "veja, perdemos as eleições aqui com braços abertos e com a rede que a gente construiu e com todo esforço que a gente tem feito e dizer veja tudo bem, agora vocês que vão gestar, mas os princípios ficam com a gente".

Obrigado. 


\section{Palestra - A luta antimanicomial e a construção dos direitos e das políticas na área de saúde mental}

Coordenação: Prof. ${ }^{a}$ Dr. ${ }^{a}$ Elisabete Ferreira Mângia - Terapeuta Ocupacional, Professora Associada do curso de Terapia Ocupacional da Faculdade de Medicina da USP.

\section{Prof. Dr. Paulo Duarte de Carvalho Amarante}

Médico, Psiquiatra, Professor e Pesquisador Titular do Departamento de Direitos Humanos, Saúde e Diversidade Cultural da Escola Nacional de Saúde Pública Sérgio Arouca da Fundação Oswaldo Cruz, Coordenador do GT de Saúde Mental e Vice-Presidente da Associação Brasileira de Saúde Coletiva (ABRASCO), Presidente Honoris da Associação Brasileira de Saúde Mental (ABRASME).

Boa tarde! Primeiro eu quero mais uma vez agradecer à toda a coordenação deste evento, ao convite. Para mim é uma honra, uma satisfação estar aqui. E também é uma honra encontrar o Antônio (referindo- se a Antônio Lancetti, que precedeu a sua fala), que é um querido amigo, que eu sempre fico muito feliz em ver e muito tocado com suas palavras. Ele é uma pessoa que me ensinou muito e que me indicou um caminho Sempre fomos auto provocadores, no sentido em que um provoca o outro em questões. Escrevemos juntos, temos capítulos publicados juntos, trabalhos juntos. E temos um sonho, entre outros sonhos, de ainda publicar um "Tratado de Saúde Mental” em conjunto. Esta ideia surgiu quando escrevemos um capítulo no "Tratado de Saúde Coletiva”, organizado pelo Gastão Wagner e pela Cecília Minayo. Nós construímos este projeto. Os dois foram acometidos por doença grave e estamos resistindo de maneiras diferentes.

Hoje eu estou falando pela primeira vez sem a minha bengala. Estou muito feliz, muito emocionado. Muito emocionado em ver o Antônio, reencontrar pessoas, vários amigos. A Sônia, a Bete... são muitas pessoas. Conheço quase todo mundo e quase todo mundo me conhece. Afinal de contas, são vários anos nessa luta. O Eraldo... eu já contei a história do Eraldo em alguns locais, de quando eu estive em coma, que cheguei a ter parada cardíaca e quase morri. Nesta ocasião, eu tive uma viagem daquelas que chamam de "quase morte", eu entrei em um túnel e, quem me puxou, foi o Eraldo, que está aqui. E acordei depois de dias e a minha mulher, muito emocionada, falou: "no dia doze de 
dezembro, aniversário do seu pai, o Eraldo ligou dizendo que rufaram os tambores na casa da mãe de santo dele, e que você não ia daquela vez". E eu falei comigo: "coincidência, porque eu vi uma mão me puxando e foi a do Eraldo". Eu sempre conto isso. E o Eraldo é assim, onde eu estou, ele está. É claro que muitas coisas não são por causa de mim. Por exemplo, se tiver ensaio do "Tá Pirando Pirado Pirou”, bloco de carnaval do Rio de Janeiro, o Eraldo vai. No "Loucura Suburbana”, ele também vai. Não perde um. Então é muito emocionante ver todos os amigos, estar aqui. Eu estou numa jornada nestes dias. Participei antes de ontem do encontro do "Despatologiza", que é um movimento importante, de defesa da vida, contra a "patologização" da vida, contra a medicalização, mas mais amplo, porque este conceito, a medicalização, às vezes remete à ideia de medicina apenas. E a "patologização" é muito mais ampla. Ela é sobre, também, todas as práticas "psis", "não psis", de transformação da vida em questões médicas, em questões de doença e tudomais.

Estou, também, muito feliz de estar com outros amigos, como o Massimo Canevacci, meu professor e antropólogo dos mais importantes. Ele não gosta que eu fale isto, porque revela uma certa idade (risos), mas quando eu estudava medicina, há mais de quarenta anos, eu estudei em livros do Massimo Canevacci. E tive a honra depois de conhecê-lo, e ele está aqui, mora agora em São Paulo e tem um dos livros mais bonitos sobre São Paulo, chamado "São Paulo, Cidade Polifônica". Ele é um antropólogo de nome internacional e uma reverência. Estou feliz em estar com a Professora da Universidade de Sassari Maria Grazia Giannichedda, presidente da fundação Franca e Franco Basaglia, de Roma, que está aqui. Eu vou pedir que depois ela fale um minutinho sobre a ideia da fundação Franca e Franco Basaglia, porque estamos querendo, neste momento que estamos vivendo, de ter acesso a estes trabalhos, a esta produção política. Também estou feliz por estar com minha chefe no "Conselho Consultivo da Fundação Franca e Franco Basaglia" e no "Conselho Consultivo da Conferência Mundial para Saúde Mental do Mundo, Franca e Franco Basaglia”, dos quais sou membro, que é GiovaNna Del Giudice. Então, é uma satisfação estar aqui com todo mundo.

Eu tenho uma preocupação, que eu tenho falado e debatido com determinados atores sociais que falam: "minha questão é científica; eu defendo o TDH, o conceito, o uso de ritalina ou qualquer outra coisa; eu defendo a internação compulsória; eu sou a favor da comunidade terapêutica cientificamente, e vocês são ideólogos; vocês fazem ideologia, vocês fazem utopia, vocês são sonhadores, idealistas”. O ministro (da saúde) falou isto agora para nós, na reforma sanitária. Nós estávamos ontem e hoje em uma reunião da diretoria da Associação Brasileira de Saúde Coletiva (ABRASCO), da qual 
sou vice-presidente, com muita honra. O presidente é o Gastão Wagner, que deveria estar aqui. E eu tenho falado: "então está bem, vamos declarar; é o seguinte, eu sou Paulo Amarante, eu não sou sócio de OSS (Organização Social de Saúde), eu não sou sócio de clínica psiquiátrica, eu não tenho comunidade terapêutica, não tenho ambulatório (aplausos). Não represento nenhuminteresse.

Qual interesse que eu defendo? O interesse da saúde pública, o interesse do cidadão brasileiro. Isto tem sido a minha história. Eu estou há quarenta anos neste projeto. Sou hoje da Fundação Oswaldo Cruz, mas comecei no Cebes (Centro Brasileiro de Estudos de Saúde). Então, na apresentação, eu vou falar um pouco do futuro, mas nós vamos falar muito do passado também lembrando pessoas. Fundamos há quarenta anos, aqui em São Paulo, o "Centro de Estudos de Saúde", o Cebes, sob a liderança de David Capistrano da Costa Filho que foi uma pessoa fundamental na história do movimento sanitário brasileiro. O Cebes elaborou a proposta do SUS, a Associação Brasileira de Saúde Coletiva, a Associação Brasileira de Saúde Mental. Foi quando criamos a revista "Saúde em Debate", da qual eu fui editor por vinte anos. Esta tem sido a minha trajetória; o movimento da luta antimanicomial. Mais recentemente estou na Coopersam (Cooperativa de Trabalho dos Professores e Serviços de Saúde). Também fui convidado pela Giovana Del Giudice, do "Conselho Consultivo" e da "Associação Franca e Franco Basaglia" gênero e a pessoa Franca, que foi uma grande autora, colaboradora, pessoa muito importante que participou do movimento social, que escreveu, produziu, publicou, teve uma atuação, foi senadora da república, porém ficava muito atrelada à figura do Franco. Então é uma justiça importante. Eu aproveito para fazer a divulgação da página do Laps (Laboratório de Estudos e Pesquisas em Saúde Mental e Atenção Psicossocial), pelo site laps.ensp. fiocruz.br. Quem quiser entrar na página, lá tem inúmeros cartazes, camisetas, botons, imagens, documentos da reforma psiquiátrica e da luta antimanicomial que eu consegui reunir destes quarenta anos e estou digitalizado e colocando lá. $\mathrm{O}$ acesso é aberto, gratuito, disponível para quem quiser ter, pegar, matar saudade e olhar as ideias. Este material está lá porque foi uma produção política subjetiva fundamental, destes anos todos, através destas camisetas, destes dizeres, destas falas, que nós temos com a sociedade. Nós construímos este imaginário. Nós transformamos a percepção da sociedade sobre a loucura, sobre a diferença, sobre a diversidade. Isto tudo foi instrumento de luta e de construção social, que nós fizemos este tempo todo. Então eu não queria perder esta memória. Foi assim também com os cartazes e com os documentos, e, então, fizemos esse site que é o site da memória da reforma psiquiátrica brasileira. Então eu estou tirando fotos. Agora a cada semana eu tiro uma foto com uma camiseta histórica e coloco no Facebook, fazendo com isso uma homenagem e um movimento de resistência também, 
ajudando a reforçar esta luta, este imaginário que nós construímos há tanto tempo com essa ideia de que as pessoas têm direitos, são sujeitos, são parte, são atores protagonistas desta luta. Quem quiser, muitas das imagens que eu uso aqui estão aí.

Quando nós começamos, há quarenta anos, nós tínhamos quase cem mil leitos psiquiátricos no país. Então, temos algumas imagens históricas como aquela mulher esquecida em uma cela, que foi abandonada e morreu ali, ressecou o corpo. A maior parte de tudo que gastavam com psiquiatria era com hospitais. Esta foto é de uma pessoa internada no Hospital do Juqueri.

Muitas pessoas não sabem, mas o Juqueri chegou a ter dezesseis mil camas, dezesseis mil internos que viveram situações de extrema violência. Você olha aquela pessoa (referindo-se ao slide) e você não acredita que ela estivesse em uma instituição de saúde, em uma instituição em que ela estivesse sendo cuidada, mas sim, em um campo de concentração, em um campo de refugiados. Foi neste contexto que aconteceu a luta pela redemocratização. O processo que nós vamos viver agora, que não sei como chamar neste momento, exige resistência ao retrocesso à ditadura às outras formas de autoritarismo que nós estamos começando a viver agora.

A nossa luta ficou importante. Ela tomou uma dimensão muito mais ampla, porque nós não só mudamos um modelo assistencial. Nós não mudamos só para melhorar os hospícios. Nós pegamos esse mote (o da redemocratização) e começamos a lutar por direitos, por igualdade. Começamos a lutar para que as pessoas fossem consideradas sujeitos e entrassem nesta política. Por isso que o movimento da luta antimanicomial brasileiro é muito importante e muito conhecido internacionalmente. Porque ele não é só um movimento de humanização de paciente, de assistência. É movimento de construção de cidadania. As pessoas tornaram-se sujeitos. Muitos estão aqui dentro. Muitos estão no nosso cotidiano participando de eventos, de seminários, de congressos, de atividades. Praticamente nada mais do que nós organizamos neste país, deixa de contar com a participação destes sujeitos. Cada vez mais.

No início falávamos pacientes, depois clientes. A própria Nise da Silveira falava assim. Depois começamos a falar usuários. Agora falamos sujeitos e em alguns países já começam a falar "ex- pacientes", "ex-usuários" ou "psiquiatrizados", no movimento de vítimas da psiquiatria. Outras expressões que não definem, a partir de uma condição, de um diagnóstico, de uma situação como se fossem pessoas acometidas de alguma forma. Cada vez que eu ouço portador de transtorno mental eu faço questão de chamar a atenção das pessoas que a gente tem que superar esse tipo de nomeação. Não sei se a Giannichedda (Maria da Graça) e a Giovanna (Del Giudice) conhecem esta foto (referindo-se ao slide). 
Eu tenho a honra histórica de ter o negativo desta foto. Eu tenho o negativo de várias fotos, que eu mostro nos slides. Esta é do Franco Basaglia (referindo-se ao slide). Eu gosto de ver esta foto (referindo-se ao slide). A minha mulher brincava "você é maluco, Paulo". Isto porque eu fui lá para Quixadá, no interior do Ceará, discutir com uma escola de nível médio, com estudantes da escola, sobre a questão antimanicomial. E quando eu mostrei esta foto (referindo-se ao slide), eu falei: vocês acham que este moço está onde? E todos respondem: "na cadeia, na cadeia". Eu fiz isto um pouco forçar as pessoas a pensarem, e respondi: "não, isso é um hospital". Este é o Franco visitando o hospital de Barbacena. Nós fizemos as fotos que foram usadas no livro e no filme depois do Holocausto Brasileiro. Nós publicamos estas fotos originalmente, em 2008. Elas estão todas disponíveis em um PDF chamado "colônia uma tragédia silenciosa". Eu vou disponibilizar para vocês depois, se quiserem. Olhem só, algumas das fotos (referindo-se aos slides). É algo impressionante. O Helvécio Ratton, cineasta que fez o filme "Em Nome da Razão", dizia que quando ele mostrou o filme, muitas pessoas elogiaram como ele conseguiu recuperar, fazer os cenários. E isto não é cenário! É um filme com cenas originais. Não tem nenhuma reencenação hollywoodiana, como em "A Lista de Schindler". O filme foi feito com cenas reais e muito mais cruéis do que se tivessem sido interpretadas. Então o "Movimento dos Trabalhadores de Saúde Mental" começou e teve uma influência muito forte no movimento argentino, no movimento latino-americano (referindo-se ao slide) - eu queria registrar isto, queria até que o Antônio tivesse aqui (referindo-se ao Antônio Lancetti). Foi em 1986 (referindo-se ao slide), lá em Buenos Aires, de 17 a 21 de dezembro de 1986. Está fazendo trinta anos que o Encontro Latino-Americano de Alternativas da Psiquiatria usou essa expressão "Por uma Sociedade sem Manicômios". Foi a primeira vez, um ano antes de aqui de Bauru, quando nós conseguimos fazer o encontro. Então, este conceito, esta ideia de uma sociedade sem manicômios teve uma importância muito grande e trouxe duas formas de rupturas. Uma no movimento que parava de falar só da humanização, de melhorias do hospital, a mudança no modelo assistencial, para uma sociedade sem manicômios. Deslocava para a sociedade. E, por outro lado, retirava o protagonismo exclusivamente dos profissionais de saúde mental, que tinham a ideia dos trabalhadores de saúde mental, para a sociedade. A sociedade como meio e a sociedade como fim. A ideia de usar a sociedade como transformação cultural. Esta foi uma das ideias fundamentais que deu origem a todo este processo de participação, que não somos nós os profissionais que fazemos, mas a sociedade como um todo, com a participação dos usuários, e aí começamos as conferências.

Eu queria lembrar e fazer uma observação histórica em relação a $1^{\mathrm{a}}$ Conferência Nacional de Saúde Mental. Esta conferência contou com a participação de usuários, só 
que naquele conceito. Foi a partir da $8^{\mathrm{a}}$ Conferência Nacional de Saúde, que foi convocada a participação da sociedade, então os usuários não eram exclusivamente as pessoas com algum diagnóstico psiquiátrico. Os usuários eram os representantes da sociedade, eram pessoas de movimentos sociais, de sindicatos, de partidos, de movimentos religiosos e quaisquer outros movimentos. Foi assim que começamos a construir este processo de participação, sem igual no mundo. Não tem no mundo. Então, esta é uma reivindicação que precisamos continuar a fazendo, e que, agora, nós deveremos continuar fazendo. Tivemos aqui no país em algumas situações que, mesmo em governos democráticos e populares, nós não tivemos a Conferência Nacional de Saúde Mental. Hoje na reunião da Abrasco (Associação Brasileira de Saúde Coletiva) com o Gastão (Wagner de Souza Campos), ele disse: "muitas pessoas falam que o congresso, a conferência às vezes não resolve. Nós não temos que necessariamente construir leis, portarias e etc. O próprio processo participativo é um processo de construção social, de criação de consciência, de criação de constância, de política, de projeto, de vida. E ele vai se transformando. Quantas pessoas a partir de uma participação dessa construíram, transformaram as suas posturas, os seus entendimentos? Transformaram o serviço, as instituições locais onde eles atuam?" Nós fizemos o $1^{\circ}$ Encontro Nacional da Luta Antimanicomial em 1993, em Salvador - BA, na praia de Piatã. Essa praia é linda, lá no Sesc (Serviço Social do Comércio) de Piatã. Então, neste slide eu coloquei "Sob o luar de Piatã", uma crônica que eu escrevi. E pela primeira vez (no $1^{\circ}$ Encontro Nacional da Luta Antimanicomial) tivemos participação de familiares e de usuários do Brasil inteiro. Pessoas que tinham vivido em hospício, passado anos da vida trancafiados e isolados, viajaram pelos seus estados, viajaram de avião. No $3^{\circ}$ Encontro, em Porto Alegre - RS, eu me lembro com muita emoção, que eu estava sentado na porta do jardim onde seria o Encontro, quando chegaram dois ônibus de usuários, familiares e técnicos, de Belém do Pará. Belém do Pará! Atravessaram o país para participar. Então todo esse processo de organização e mobilização das pessoas, de ir, sair, viajar e fazer, isto tudo é uma forte expressão da construção de cidadania, de subjetividade que nós estávamos fazendo, de novos sujeitos que estavam entrando nesta política. Esta foto é lá em Piatã. Estas são as barraquinhas dos nossos encontros. Nós conversando, construindo, pensando ideias, e eu fiquei muito emocionado. Eu tinha acabado de ler uma crônica do Eduardo Galeano, que dizia que "um menino nunca tinha visto o mar e ele pediu ao pai para levá-lo para ver o mar. Chegando lá, subiram em uma colina e viram o mar. O menino ficou louco quando viu aquela coisa. Realmente é fantástico, o mar. O pai já conhecia o mar, por isto, distraído olhava para o lado. Então, o menino balançou a mão do pai e disse: pai, me ajude a olhar". Isto é uma coisa que não dá para sentir sozinho. Esta ideia de a gente construir 
este espaço, construir este movimento coletivamente. Quantos amigos, quantas histórias, quantos percursos nós vimos aí. Esta foi a última camiseta que eu vesti (referindo-se a foto no slide "Diga não ao manicômio" esta é uma camiseta feita em Brasília. A ideia do movimento social "por uma sociedade sem manicômios" em Bauru, em 1987. Criamos lá, tem muitas pessoas aqui (que estavam lá). Então começamos a comemorar todos os anos, no dia 18 de maio, o "Dia Nacional da Luta Antimanicomial". E começamos a fazer atividades.

Teve uma vez que eu fui de manhã em uma mesa em Porto Alegre - RS e saí correndo para participar de uma mesa em Belém, no Pará. Eu não dava mais conta. $\mathrm{O}$ dia 18 (de maio), o dia nacional ficou pequeno. Então nós começamos a fazer a semana da luta antimanicomial. Aquele dia virou a semana da luta. E depois maio virou mês da luta antimanicomial. Em maio tem atividades políticas, sociais, culturais, científicas de primeiro ao último dia, em todo o país, em todo o canto da cidade, nas universidades, nas câmaras, nos Ministérios Públicos, nas defensorias, por aí afora. Fizemos da luta antimanicomial, uma luta cotidiana, das relações. Seja nos serviços, nas cooperativas, nos trabalhos, em todo lugar. E transformamos e isto é a nossa luta. Mas eu queria dizer isto: esta luta será enfrentada muito fortemente pelos setores conservadores, pessoas que não querem os mesmos direitos, seja para mulheres, para negros, para índios, caboclos, para gays, para tudo. Nós vamos enfrentar muita luta cotidiana. E o fato de acabar com um ou outro serviço não irá nos enfraquecer, porque nestes anos nós construímos não apenas novos serviços, que são muito importantes, mas nós construímos novas relações sociais, nós construímos novos sujeitos, novas práticas que estão no dia a dia. As pessoas que experimentaram sair de uma instituição, e nestes cerca de 60.000 leitos que nós fechamos, nós tiramos muitos milhares de vidas da carreira moral de pacientes de instituições totais. Tiramos muitos milhares de vidas de dentro destas instituições e com elas construímos outras possibilidades. E nós estamos cheios destas histórias. Nós temos no nosso cotidiano várias pessoas, vários nomes que saíram, que viveram, que reinventaram suas vidas, mas também impedimos que milhares de pessoas entrassem naquela carreira [moral] de exclusão, oferecendo novos serviços, novos projetos, novos dispositivos, novas estratégias de vida.

Quantas 60.000 pessoas não entraram naqueles leitos que nós fechamos? E estão por aí na vida reconstruindo, refazendo. Isto é um dos nossos trunfos. Nós não estamos só no serviço. Nós alcançamos a sociedade e o cotidiano de todas estas pessoas. Por isso que eu estava dizendo que a reforma psiquiátrica, neste sentido, para nós, não foi só a reforma de serviço. Não foi só mudança do modelo assistencial. Ela tem sido e é a 
construção de novas relações com as pessoas que nós chamamos de "com diagnóstico psiquiátrico", agora.

Porque é um fato. Ela tem transtorno, portador de transtorno ou usuário. Porque ela não se reduz só a usar o serviço ou usar alguma coisa. Ela é uma pessoa. Ela tem sexo, ela tem nome, tem naturalidade, tem time. Tem mulheres ou maridos. Tem várias opções de vida. Ela não é só aquilo. E muito menos um diagnóstico. Então eu escrevi um capítulo aqui (referindo-se ao slide). (uma vez) eu vim em um seminário aqui em São Paulo, o cara se apresentou para mim: o senhor é o doutor Paulo Amarante? Muito prazer, José Roberto, bipolar (risos da platéia). As pessoas se identificam a partir de um diagnóstico, é identidade. E isso é muito interessante, porque muitas destas pessoas que nós conhecemos se apresentavam como "sou paciente do CAPS tal", "sou usuário" ou "sou cliente". E agora falam "eu sou da cooperativa "Louca Sabedoria”, "eu sou do grupo geração de renda tal", "eu sou do coletivo de saúde mental de Santo André", "eu sou do grupo, etc “. Elas deslocam a sua identificação, o que elas fazem de si, e com isso deslocam a identificação que nós fazemos dela de uma ideia de um diagnóstico, de um paciente, de um usuário, para um cidadão. Então é isto: eu vou ser o quê? "Eu sou paulista". "Eu sou o quê?" "Você quer saber que eu sou de quê?" Não, aqui você é um segmento: usuário, técnico ou familiar. Então vamos mudando esta construção social. Eu acho que isto é importante, como nós observamos isto que nós conseguimos fazer, que nós estamos fazendo. Estamos deslocando milhares de pessoas de identificações que eram a partir do diagnóstico, a partir da sua inserção social. Esta ilustração "por uma sociedade sem manicômios/ há tanta vida lá fora", é lá de Betim - MG, eu fui guardando esta produção. Uma aluna de doutorado até fez uma tese, com vários trabalhos de imagens, designs. É muito interessante esta questão de como uma propaganda que nós fizemos, um marketing, uma mídia que nós construímos, reflete na mudança da imagem que a sociedade faz, que as próprias pessoas fazem, como feio (referindo-se à loucura). Nós conseguimos criar um diálogo a partir das camisetas, dos fóruns, dos cartazes, porque fundamentalmente o nosso trabalho, como diz o Bakhtin (referindo-se à Mikhail Bakhtin, teórico russo), é de diálogo.

Nós queremos dialogar. Diversidade de diálogo é conseguirmos falar com as pessoas, de lugares diferentes. O Boaventura (referindo-se à Boaventura de Souza Santos, teórico português) fala em traduzir ideais, traduzir ideias, traduzir projetos de vida. Então, esta é a ideia. Este é um cartaz histórico, lá no Rio Grande do Sul (referindo-se ao slide), da Carmem Oliveira "de militonto a militante". Depois nós invertemos também e falamos que pode ser de militante a militonto, porque nós não devemos descriminar. Por que 
o militonto não é importante? É, sim. Foi pelos militontos também, que a sociedade evoluiu, não é? Se for só aqueles militantes do “o que é isso, companheiro?”, nós não teríamos feito as loucuras necessárias que fizemos. Para fazer a marcha dos usuários, fazer as exposições que nós fizemos por aí afora, no mundo. Para mim, isto foi consequência de uma estratégia consciente. Sempre me lembro que nós estamos em um processo de transformação da vida e do serviço, que tem uma fundamentação teórica. Tem uma referência conceitual. Uma delas foi a discussão de Basaglia (referindo- se a Franco Basaglia, teórico italiano) de que a psiquiatria colocou sempre "o homem", entre parêntese, "o sujeito", para ser o culpado da doença, das síndromes, da esquizofrenia. Como se elas existissem palpavelmente, fossem objetos. E ele dizia: "eu nunca vi uma esquizofrenia". Aí, um colega dele, teórico, falou: "não? Você nunca entrou em um hospital?". (Respondia Basaglia) "eu entrei e vi muitas pessoas violentadas, vitimadas e isoladas, que chamávamos esquizofrênicos, mas a esquizofrenia sem as pessoas não existe". São as pessoas com reações, com situações, que nós, na falta de outra forma de definição ou por imposição, chamamos de esquizofrênicos. Então é necessário que façamos o contrário. (Devemos) inverter, colocar "a doença”, entre parêntese, para nos ocuparmos dos sujeitos. Quando ele (referindo-se a Basaglia) fez isto, ele fez uma alteração epistemológica, mas também ética e política. (Basaglia) começou a ver quem era o sujeito, que tinha um nome, que tinha um desejo, que tinha um projeto, que precisava além de um remédio, de um tratamento correto, precisava de casa, de namoro, de passeio, precisavam de trabalho. Precisavam de vida, e de construir, de esporte, de tudo. De lazer, de praia, e tudo mais. Então, a partir deste contexto nós passamos a pensar que o CAPS não é só um serviço de saúde mental, mais politicamente correto e mais organizado, mas uma estratégia de inserção no território. São os mediadores a partir do CAPS, de uma cooperativa ou de uma situação, que ajudam as pessoas a construírem com elas outras possibilidades, outras sociabilidades, outros projetos de vida. Esta foi a ideia fundamental. E daí nós saímos só dos ambulatórios.

E aí eu trago uma provocação às pessoas que também têm uma atitude centrada na ideia da clínica, que é só uma nova clínica. Não é só a ideia de uma nova clínica. Se você epistemologicamente pode colocar "o conceito", entre parentes, para lidar com o sujeito, colocar a psiquiatria, então você também tem que colocar a sua "relação mediada pela clínica”, entre parêntese. Então, à clínica, não basta colocar o objeto. Tem que ter esta relação, que sempre será uma relação também de poder. Nunca será uma relação neutra. Nunca será uma relação apenas cientificamente pré-determinada. Por isto que faço esta provocação. (referindo-se ao slide) (foi) a partir do Foucault (referindo-se a Michel Foucault, teórico francês) da ideia positivista de que "penso, logo existo", (que 
surgiu) esta consciência. E o Foucault falou: mas para que serve (esta consciência), se você critica tudo, é reflexo de tudo. Nós precisamos hesitar mais. Se nós hesitássemos mais ao pegar uma pessoa e dar um eletrochoque, amarrá-lo na cama, dar um remédio, fazer uma medicação, talvez nós errássemos menos. Então é necessário que hesitemos mais. Hesitar no sentido mais amplo, dialético, de pensar, de refletir. Este cartaz (referindo-se ao slide) é uma homenagem à experiência riquíssima de Santos - SP, Lancetti estava aqui e tem tanta gente que participou. Esta ideia de novos sujeitos: gente não é para tomar eletrochoque, gente não é só para tomar remédio, gente não é para ser trancafiada. Gente é para brilhar. Esta é a estratégia que nós sempre tivemos. "Há tanta vida lá fora" é música do Lulu, não é? E gente é para brilhar, não para morrer de fome. E como diz o Caetano: "de perto, ninguém é normal". Então foi uma estratégia bem-sucedida do movimento antimanicomial de usar palavras, significados, símbolos da cultura para a partir daí traduzir e recolocar a questão da loucura e da diversidade.

Para encerrar, queria lembrar do Carrano (referindo-se a Austregésilo Carrano Bueno, curitibano, autor do livro "Canto dos Malditos", que baseou o filme "Bicho de Sete Cabeças") e a questão toda dos direitos humanos, (que) é uma luta importante, fundamental. Vocês conhecem o Carrano? "O Bicho de Sete Cabeças" (referindo-se ao filme) tem quinze anos, e foi o filme inspirado no livro do Carrano, que conta as violências que ele sofreu em instituições psiquiátricas. Ele (referindo-se a Carrano) acabou sendo penalizado pela justiça do Paraná a não falar mais o nome da clínica ou do serviço (psiquiátrico que foi internado) e recolheram os livros dele. Esta foto é real, não é simbólica (referindo-se ao slide). O Carrano se acorrentou, se amordaçou e ficou em frente ao fórum do Paraná até que o livro fosse autorizado. E não foi. E ele foi penalizado, teve que pagar ao cara que o torturou, que o prendeu, que o violentou lá na clínica. Foi em 2003, 2004. Logo depois que saiu o filme. Eu queria apenas fazer menção (referindo- se ao slide) desta ideia de que este movimento, este processo construiu novos serviços, mas também construiu práticas políticas importantes no campo do direito, dos direitos humanos, da inserção social do sujeito e através da cultura também. Então eu queria revalorizar isto, como nós construímos neste processo brasileiro, tantas experiências de ressignificação da vida, muitas delas a partir da cultura. Aqui em São Paulo temos 'O Coral Cênico Cidadãos Cantantes", A “Livraria Louca Sabedoria”, o "Cordão Bibitantã”, o "Trem Tan-tan", em Santos. Experiências culturais que deslocaram a ideia de que a reforma, o movimento enfrenta só a questão da violência no hospício ou o tratamento, mas que foram aberturas para novas possibilidades das pessoas se verem no mundo, de estarem no mundo. O Peter Pelbart fala de uma pessoa que dizia "sou paciente" e depois começou a se apresentar "eu sou ator", "sou iluminador", "sou cenógrafo". E isto é uma 
transformação profunda na vida. Não é só uma nomeação. Elas se colocam de uma maneira diferente, são vistas de maneiras diferentes. Esta ideia do movimento, da expressão, de todas as conferências, dos congressos da Abrasme, isto tudo tem que ser valorizado. Coloquei um Cristo (referindo-se ao slide) de braços abertos em homenagem ao "De Braços Abertos" (aplausos). Já pedi autorização a Sônia (referindo-se à professora doutora Sônia Barros, presidenta do evento) para que Maria da Graça Giannichedda, que é uma honra ter aqui, falasse um minuto para a gente sobre a Fundação Franca e Franco Basaglia, porque nós estamos fazendo um trabalho de aproximação cada vez mais com esse instituto, de um projeto importante nesse momento, muito fundamental para nós. Antes de eu encerrar, queria que ela falasse. Maria da Graça, porfavor.

Ela vai falar primeiro da história de uma camiseta. Uma camiseta em que está escrito: "de perto ninguém é normal". Esta é uma frase usada em uma camiseta que foi presenteada por amigos brasileiros aos italianos, que a reproduziram infinitamente e todo mundo ligado ao movimento, lá na Itália, usa esta camiseta. Ela está trabalhando no Japão e levou a camiseta para lá. Então, por meio da Itália, a camiseta chegou no Japão e agora está lá em japonês “de perto ninguém é normal” (risos da plateia).

Alguns anos atrás, em uma cidade próxima a Roma, existiu também um movimento, um processo, um encontro atividades culturais, de pessoas que foram de cooperativas, de projetos culturais, loucos, etc. E deram uma camiseta para ela nesta festa, "que de perto ninguém é normal - Franco Basaglia", como se ele tivesse falado. Ela vai botar esta camiseta para tirar foto e eu vou colocar no meu Facebook. Para ela é muito importante essa frase, porque é bonita no sentido poético, mas também no epistemiológico e filosófico, porque ela diz "afinal o que é verdade, o que é falso?" Não foi Franco quem falou isto. Quem falou foi Caetano Veloso. Mas isto não foi Franco quem falou, mas poderia ser verdade, porque Franco muito provavelmente teria falado essa frase. (Traduzida simultaneamente e comentada por Dr. Paulo Amarante)

Maria da Graça Giannichedda: Isto é muito importante porque isso traduz de uma certa forma, estas relações que nós temos entre o movimento, de afeto, de proximidade. Esta relação entre Brasil/ Itália, esses dois movimentos, é uma relação de muita aproximação, de vizinhança, fundamentalmente uma relação de companheirismo. Isto continua sendo uma relação de fraternidade, de parceria, um termo muito importante. Nestes dias que estou aqui no Brasil, comecei a sentir uma coisa preocupante entre os 
brasileiros. Como se fosse algo como uma depressão que eles estão vivendo. Depois entendi como sendo uma tristeza política. Este é um sentimento que entendo bem, porque também vivi isto nestes quarenta anos, entre vai e vem, de grandes dificuldades, de muitos problemas. É uma sensação de que a questão não está só em ter somente otimismo. Que nós, também, temos que ter a desilusão, reconhecimento do próprio limite, o limite da própria força. Ao longo destes quarenta anos, na Itália, estamos muitos felizes e temos consciência de muitas coisas que fizemos. Não apenas o fechamento de hospitais, a criação de novos serviços, de vários projetos culturais, mas temos também a consciência de que precisamos fazer muitas coisas ainda. Eu penso que a Giovana Del Giudice deve ter falado da campanha que nós abrimos contra o uso da contenção física. E eu falei estes dias: vim para expor, para falar do movimento que está tendo na Itália neste momento para o fechamento dos manicômios judiciários. Nós temos conseguido muitas coisas e temos orgulho de tudo isto que nós conseguimos, mas também sentimos falta de muitas coisas que ainda se deve fazer para que não se retorne ao estágio anterior. Eu não sei se a Giovana falou aqui, mas na Itália, em 2014, foi aprovada uma lei que determina o fechamento dos manicômios judiciários. Então, estamos querendo o fechamento verdadeiro, a extinção da medida desegurança.

Prof. Dr. Paulo Duarte de Carvalho Amarante: E está é uma batalha que teremos de fazer. (Traduzida simultaneamente por Dr. Paulo Amarante)

Maria da Graça Giannichedda: Sim, eu falo porque falo da história do movimento brasileiro. E nós também teremos o mesmo problema de entregar a história do movimento italiano nas mãos dos mais jovens, porque nós vemos a 10 quilômetros, mas tem mais quilômetros ainda, muitos. A Fundação Basaglia, junto com outras coisas que criamos, tende a ser também isto, uma coisa que chamamos oficina de cidadania. E, nestas oficinas de cidadania, tentamos fazer, trabalhar juntos com jovens de dezesseis, dezoitos anos na escola. E, tentamos produzir um encontro direto entre os jovens das escolas, entre dezesseis e dezoito anos, com os jovens da associação de usuários, é uma péssima palavra (referindo- se ao termo usuário), mas, digamos, que fazem rádio, que fazem cooperativa. É função do laboratório de cidadania, mais do que falar sobre a desestigmatização que produz participação e cidadania. Isto é uma pequeníssima coisa no mar em que o mundo está navegando/andando. Porque eu acho que vocês só têm a tristeza política, porque eu acho que a situação política neste país é muito difícil. Muito difícil. Um filósofo que eu gosto muito, é Espinoza, Baruch Espinoza, que era muito va- 
lente quando disse isto, mas não era um líder político, era muito solitário. E disse uma coisa que eu acho muito importante: "cada um de nós tem que lutar contra as situações/ paixões tristes. As situações tristes/paixões são os sentimentos que tem o poder de te convencer que você é impotente e que a única coisa que você pode fazer é ser exilado e rancoroso. Rancoroso e desencantado". É muito importante, Espinoza dizia que nós combatamos a situação triste. (aplausos) Muito obrigado! 


\section{COMISSÃO ORGANIZADORA DO II ENCONTRO DE SAÚDE MENTAL E REABILITAÇÃO PSICOSSOCIAL: AVANÇOS E DESAFIOS NOS 15 ANOS DA LEI 10.216}

\section{Presidente}

Prof. a Dr. a Sônia Barros

Vice-Presidente

Dr. Luís Eduardo Batista

Comissão Administrativa

Ms. Jussara Carvalho dos Santos - coordenadora

Comissão de Apoio ao Evento

Ms. Laís Mariana da Fonseca - coordenadora

Esp. Carolina J. S. Salado

Comissão Financeira

Prof. ${ }^{a}$ Dr. ${ }^{a}$ Márcia Aparecida Ferreira de Oliveira - coordenadora

Prof. ${ }^{a}$ Dr. ${ }^{a}$ Sônia Barros

Dr. Luís Eduardo Batista

Comissão de Divulgação

Ms. Luciane Régio - coordenadora

Ms. Neuri Pires das Merces Natalia P. Cafarelli (graduação)

Cristhian R. Schieck (Residência) 
Comissão de Recepção

Ms. Lara S. Messias Floriano - coordenadora

Ms. Rosana Ribeiro Tarifa

Cristhian R. Schieck (Residência)

Comissão Local

Ms. Anaísa Cristina Pinto - coordenadora

Ms. Naira Gajo Silva

Comissão de Apoio ao Congressista

Ms. Naiara Gajo Silva - coordenadora

Fernanda Souza Silveira (Residência)

Fernanda Azevedo (graduação)

Gabriela Boska (Residência)

Ms. Lígia H. B. Santos

\section{Comissão Científica}

Prof. a Dr. a Sônia Barros (EE-USP) - coordenadora

Prof. ${ }^{a}$ Dr. ${ }^{a}$ Maria do Perpétuo S. S. Nóbrega (EE-USP)

Prof. Dr. Jandro Moraes Cortes (EE-USP)

Prof. ${ }^{a}$ Dr. ${ }^{a}$ Paula H. Pinho (UNIFESP)

Prof. ${ }^{a}$ Dr. ${ }^{a}$ Márcia Ap. Ferreira de Oliveira (EE-USP)

Prof. ${ }^{a}$ Dr. ${ }^{a}$ Fernanda Nicácio (FOFITO-USP)

Prof. Dr. Pedro G.G. Delgado (UFRJ) 


\section{APOIO}

Área técnica de saúde mental da Secretaria Municipal de Saúde de São Paulo, DECIT/ Ministério da Saúde, CAPES, CNPq, FAPESP, CRP/SP, CEAPE/EE 


\section{Notas}

1 "O que resta de Auschwitz", autor Giorgio Agamben. 